FABIOLA MARGOTH ZAMBRANO FIGUEROA

\begin{abstract}
AVALIAÇÃO DE MADEIRA DE PEROBA-ROSA POR MÉTODO NÃO DESTRUTIVO UTILIZANDO EMISSÃO DE ONDAS DE ULTRASSOM
\end{abstract} PARA PEÇAS ESTRUTURAIS DO PATRIMÔNIO HISTÓRICO

Dissertação apresentada à Escola Politécnica da Universidade de São Paulo para a obtenção do título de Mestre em Engenharia Civil. 
FABIOLA MARGOTH ZAMBRANO FIGUEROA

\section{AVALIAÇÃO DE MADEIRA DE PEROBA-ROSA POR MÉTODO NÃO DESTRUTIVO UTILIZANDO EMISSÃO DE ONDAS DE ULTRASSOM PARA PEÇAS ESTRUTURAIS DO PATRIMÔNIO HISTÓRICO}

Dissertação apresentada à Escola Politécnica da Universidade de São Paulo para a obtenção do título de Mestre em Engenharia Civil.

Área de concentração:

Engenharia de Construção Civil e Urbana

Orientador:

Prof. Dr. Vahan Agopyan 
Este exemplar foi revisado e alterado em relação à versão original, sob responsabilidade única do autor e com a anuência de seu orientador.

São Paulo, de dezembro de 2010.

Assinatura do autor

Assinatura do orientador

1 FICHA CATALOGRÁFICA

Zambrano Figueroa, Fabiola Margoth

Avaliação de madeira de peroba-rosa por método não des trutivo utilizando emissão de ondas de ultrassom para peças estruturais do patrimônio histórico / F.M. Zambrano Figueroa. -ed.rev. -- São Paulo, 2010.

$101 \mathrm{p}$.

Dissertação (Mestrado) - Escola Politécnica da Universidade de São Paulo. Departamento de Engenharia de Construção Civil.

1.Ultrassom 2.Ensaios não destrutivos 3.Madeira 4.Perobarosa 5.Patrimônio histórico I. Universidade de São Paulo. Escola Politécnica. Departamento de Engenharia de Construção Civil II. t. 
Nome: ZAMBRANO FIGUEROA, Fabiola Margoth

Título: Avaliação de madeira de peroba-rosa por método não destrutivo utilizando emissão de ondas de ultrassom para peças estruturais do patrimônio histórico.

Dissertação apresentada à Escola Politécnica da Universidade de São Paulo para a obtenção do título de Mestre em Engenharia Civil.

Aprovado em:

\section{Banca Examinadora}

Prof. Dr.: Instituição:

Julgamento Assinatura:

Prof. Dr.: Instituição:

Julgamento Assinatura:

Prof. Dr.: Instituição:

Julgamento Assinatura: 
Aos meus queridos pais, Luis e Margot e a meu noivo, Alexandre, pela sua dedicação e carinho. 


\section{AGRADECIMENTOS}

Em especial, ao meu orientador Prof. Dr. Vahan Agopyan, pelo auxílio, incentivo, disponibilidade de tempo e por seus valiosos ensinamentos.

Aos meus colegas e amigos de trabalho do Laboratório de Madeira e Produtos Derivados do IPT por terem disponibilizado tempo para ouvir minhas dúvidas com companheirismo e atenção. Em especial, aos colegas Takashi e Elias pelas importantes discussões e orientações técnicas. À Claudia, Raphael e Richard, por terem colaborado com as identificações das espécies de madeira das amostras. Ao Paulo e Zinaldo por terem dado importante ajuda na seleção das peças de madeira, na confecção dos corpos-de-prova e na realização dos ensaios. Ao Mauro por ter a disposição de viajar e percorrer um dia inteiro em busca de uma amostra de peroba-rosa. Ao Ricardo e à Beatriz pelos valiosos ensinamentos sobre a biodeterioração da madeira. Ao estagiário Felipe, que apesar da sua curta passagem pelo laboratório, ofereceu importante ajuda no avanço dos ensaios e interpretação dos resultados com as ondas ultrassônicas. E à Maria José e Geraldo por terem permitido disponibilizar parte de meu tempo de trabalho no laboratório para a realização desta dissertação.

Aos colegas e amigos do IPT, Theophilo e Edivan, por terem compartilhado comigo seis meses de vivência com o tema da avaliação estrutural do patrimônio histórico em São Luiz do Paraitinga.

Aos amigos que compartilharam as angústias e as preocupações durante a realização desta pesquisa, Poffo, Mario e Valéria. À Luciana Faria, Lígia de Oliveira e Luciana de Oliveira pela amizade e apoio.

Aos amigos que conheci graças a esta pesquisa, Lúcia, Rafael e Fádia.

Aos amigos da arquitetura que assim como eu, acreditam que se deve investir no patrimônio histórico, Mita, Rosângela e Leandro.

À equipe do laboratório da EPUSP-PCC, Reginaldo e Adilson, por terem ajudado nos ensaios mecânicos destrutivos.

Aos pesquisadores do Grupo Interdisciplinar de Estudos da Madeira da UFSC (GIEM), Prof. Dra. Ângela do Valle e Prof. Dr. Rodrigo Figueiredo Terezo e à Prof. Dra. Raquel Gonçalves da Faculdade de Engenharia Agrícola da UNICAMP, por 
terem me recebido cordialmente em seus laboratórios e terem me apresentado seus trabalhos que desenvolvem com o uso do ultrassom.

À CNPq por ter facilitado a aquisição de material para os ensaios.

À Prefeitura Municipal de Cravinhos por terem permitido a retirada de peças de madeira dos escombros da Igreja de São Benedito.

À Association of Preservation Technology International e ao Getty Foundation por terem oferecido a oportunidade de conhecer os trabalhos e as pesquisas no âmbito da conservação e restauração do patrimônio histórico internacional. 


\section{RESUMO}

ZAMBRANO FIGUEROA, F. M. Avaliação de madeira de peroba-rosa por método não destrutivo utilizando emissão de ondas de ultrassom para peças estruturais do patrimônio histórico. 2010. 101 p. Dissertação (Mestrado) Departamento de Engenharia de Construção Civil da Escola Politécnica da Universidade de São Paulo, São Paulo, 2010.

O objetivo desta pesquisa é avaliar uma metodologia utilizando ondas de ultrassom para estimar a resistência de peças estruturais de madeira de peroba-rosa, Aspidosperma polyneuron Müll. Arg. A metodologia pode ser utilizada para orientar projetos de restauro de estruturas de madeira do patrimônio histórico, onde de acordo com os critérios da restauração, a avaliação por métodos destrutivos não são recomendados. A verificação foi realizada em três amostras retiradas de edificações construídas há 122 anos, 50 anos e peças sem uso de madeira da espécie perobarosa, que foram submetidas à sequência de ensaios não destrutivos e destrutivos. Os corpos-de-prova ensaiados tiveram suas dimensões definidas de acordo com os métodos de ensaio de resistência à compressão e à flexão da norma ABNT 7190:1997 e o teor de umidade estabilizado na condição padrão de referência a $12 \%$. Os ensaios com o uso de equipamento de ultrassom com freqüência de $100 \mathrm{KHz}$ e transdutores de ondas longitudinais e transversais foram utilizados para a determinação da velocidade ultrassônica nos três eixos da madeira (longitudinal, radial e tangencial). Em seguida, os mesmos corpos-de-prova foram submetidos aos ensaios de determinação da resistência e da rigidez à compressão e à flexão de acordo com a norma NBR 7190:1997. O resultados dos ensaios dinâmicos e estáticos foram correlacionados, tendo, portanto sido definido o coeficiente de correlação $R^{2}=0,56$ na direção do eixo longitudinal.

Palavras-chave: Ultrassom, Ensaios não destrutivos, Madeira, Peroba-rosa, Patrimônio histórico. 


\begin{abstract}
ZAMBRANO FIGUEROA, F. M. Evaluation of peroba-rosa wood by non destructive tests using ultrasound waves for structural timber of historical heritage. 2010. 101 p. Dissertação (Mestrado) - Departamento de Engenharia de Construção Civil da Escola Politécnica da Universidade de São Paulo, São Paulo, 2010.
\end{abstract}

The objective of this research is to evaluate a methodology by making use of ultrasound waves to estimate the strength of structural timber of peroba-rosa, Aspidosperma polyneuron Müll. Arg. This methodology can be used to provide guidance in restoration projects of wooden structures of historical buildings, where the assessment by destructive methods is not recommended, according to the restoration criteria. The sequence of tests was performed by using both non destructive and destructive analysis methods on samples from three buildings constructed 122 years ago, 50 years ago and non used wood. The specimens tested had their dimensions defined according to the test methods of ABNT 7190:1997 for resistance to compression and bending and their moisture content was stabilized at $12 \%$. The tests using ultrasound equipment with a frequency of $100 \mathrm{kHz}$ transducers and longitudinal and transverse waves were used to determine the ultrasonic velocity in three axes of the wood (longitudinal, radial and tangential). Afterwards, the same specimens were tested to determine the strength and stiffness to compression and bending in accordance with NBR 7190:1997. The test results of dynamic and static modulus were correlated, obtaining thus the correlation coefficient of $R^{2}=0.54$ in the longitudinal direction.

Keywords: Ultrasound, Nondestructive testing, Timber, Peroba-rosa, Historical heritage. 


\section{Lista de fotografias}

\section{Lista de fotografias}

Foto 1

Casarão desmoronado durante a enchente do dia 01 de janeiro de 2010, em São Luiz do Paraitinga, o qual apresentava presença de cupins e fungos nas peças estruturais de madeira do pau-apique.

Foto 2

Igreja de São Benedito no município de Cravinhos, desmoronada após período de fortes chuvas, no dia 25 de fevereiro de 2009. Construída em 1888, foi a primeira igreja matriz da cidade e, portanto era chamada pelos moradores locais de Matriz Velha. Foi tombada como patrimônio histórico pelo município em 1985.

Fotos 3 e 4 Estrutura de cobertura e cambotas da Basílica do Bom Jesus na cidade de Tremembé, Vale do Paraíba, foi construída em 1795 e se encontra em processo de tombamento.

Foto 5 Uso de vigas de madeira, forro, assoalho e batentes em madeira no Palacete 10 de Julho em Pindamonhangaba, construído na segunda metade do século XIX para ser residência dos barões do café no Vale do Paraíba. Foi tombado pelo CONDEPHAAT em 1969.

Foto 6

Vigas, pilares e assoalho de madeira do Sobrado Vallim em Bananal/SP, construído por volta de 1850, constitui um exemplar urbano típico de viver dos fazendeiros de café. Foi tombado em 1972 pelo CONDEPHAAT.

Foto 7 Prospecção de peças de madeira em parede de alvenaria de tijolos no Palacete 10 de Julho na cidade de Pindamonhangaba, construída na segunda metade do século XIX. Está em processo de restauro. 30 
Foto 8

Foto 9

Foto 10

Foto 11

Foto 12

Foto 13

Foto 14

Fotos 15 e 16 Escombros da Igreja de São Benedito em Cravinhos durante visita em três de março de 2009 59

Foto 17

Foto 18

Foto 19

Foto 20

Foto 21

Foto 22

Foto 23

Apoio de pilar com deterioração causada por fungo apodrecedor em parede de taipa do Sobrado Vallim na cidade de Bananal/SP

Cupim de madeira seca em viga de peroba-rosa encontrada nos escombros de edificações do centro histórico de São Luiz de Paraitinga em junho de 2010. 46

Viga de madeira com ataque intenso de cupim-de-madeira-seca encontrada nos escombros de edificações do centro histórico de São Luiz de Paraitinga.

Fonte com visor e painel do equipamento de emissão de ondas de ultrassom.

Peças com altura de $50 \mathrm{~mm}$ e espessura de $30 \mathrm{~mm}$ da espécie peroba-rosa (Aspidosperma polyneuron) apresentando diferentes colorações. .55 Identificação da madeira pelo método macroscópico de analise do lenho. (Fonte: IPT, 2010).

Imagem obtida em microscópio para identificação da madeira (Fonte: IPT, 2010). 56

Tesoura retirada da reforma de prédio do CT-NAVAL do IPT, em São Paulo

Corpos-de-prova nas dimensões de $50 \mathrm{~mm}$ x $50 \mathrm{~mm}$ x $1015 \mathrm{~mm}$ para ensaios de flexão retirados das vigas adquiridas em serraria, se uso.

Escombros do casarão em frente à Praça Oswaldo Cruz na cidade de São Luiz do Paraitinga em janeiro de 2010, após enchente do Rio Paraitinga

Escombros de madeira reunidos na Praça Oswaldo Cruz, centro histórico de São Luiz do Paraitinga

Vigas de ruínas decorrentes da enchente do Rio Paraitinga........64

Ruínas da Igreja Matriz de São Luiz de Tolosa.. .65

Peças de madeira das ruínas da Igreja Matriz de São Luiz de Tolosa. 
Foto 24 Segmentos de madeira retirados das ruínas das edificações do centro histórico de São Luiz do Paraitinga, em visita do dia 20 de janeiro de 2010 66

Fotos 25 a 27 Faces tangencial, radial e fotomicrografia de Abiurana, angicovermelho e ipê, respectivamente (Fonte: IPT, 2010) 68

Foto 28 Corpos-de-prova da Amostra C acondicionados em ambiente coberto e ventilado para o controle da secagem. 72

Foto 29 Controle de medição de umidade dos corpos de prova de madeira da Amostra $C$ para os ensaios de flexão. . .73

Fotos 30 e 31 Vista e detalhe do pilar avaliado com método de ultrassom........84

Foto 32 Uso de equipamento para medir a velocidade longitudinal de ondas de ultrassom em seção de pilar de residência do século XIX em São Luiz do Paraitinga, construída com paredes de pau-a-pique, pilares e vigas de madeira e fundação de cantaria .85 


\section{SUMÁRIO}

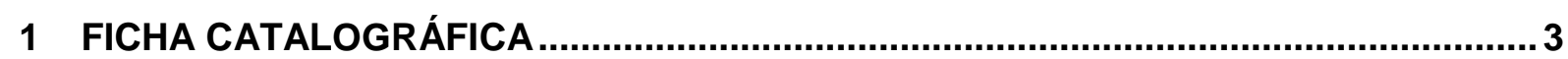

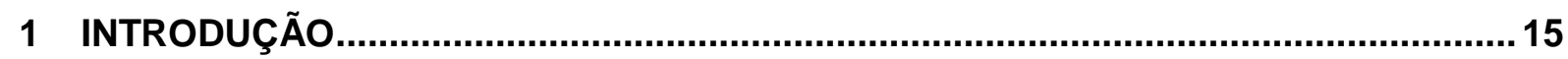

2 O USO DA MADEIRA NA ARQUITETURA DO BRASIL.............................................23

2.1 ABORDAGEM SOBRE O ESTADO ATUAL DE CONSERVAÇÃO DO PATRIMÔNIO

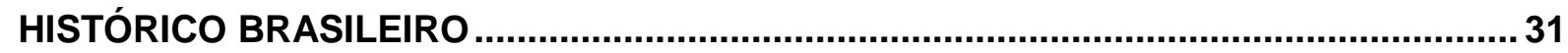

2.2 ATIVIDADES DO CONSERVADOR E RESTAURADOR DE BENS IMÓVEIS ............33

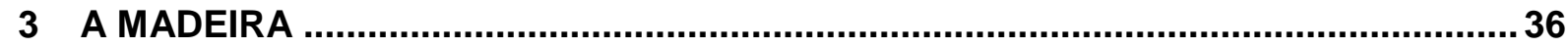

3.1 CARACTERÍSTICAS FÍSICAS E MECÂNICAS DA MADEIRA ..................................... 38

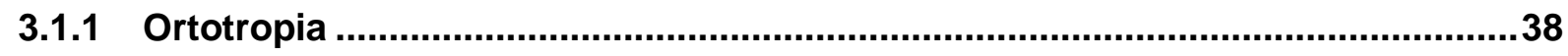

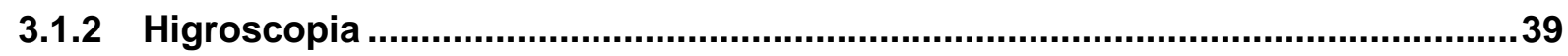

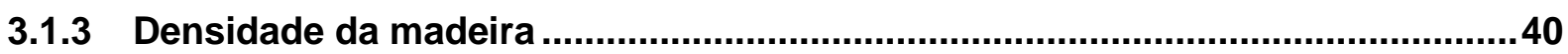

3.2 PRINCIPAIS PATOLOGIAS QUE AFETAM A MADEIRA ……................................ 41

3.2.1 Fungos apodrecedores...........................................................................................42

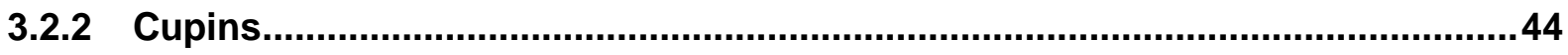

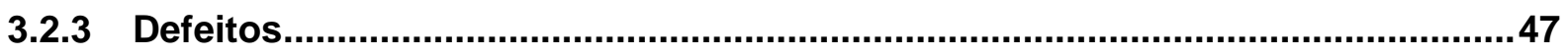

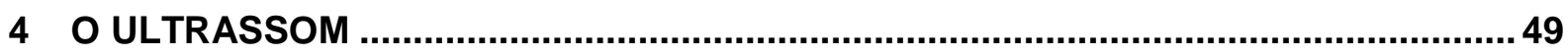

4.1 EQUIPAMENTOS DE ULTRASSOM ................................................................ 5

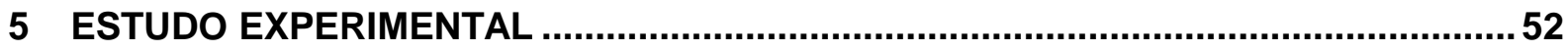

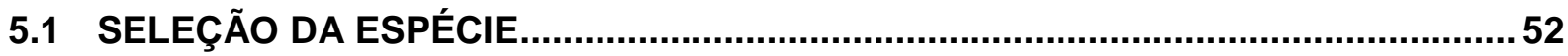

5.2 IDENTIFICAÇÃO BOTÂNICA

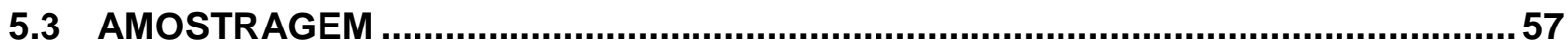

5.3.1 Amostra A

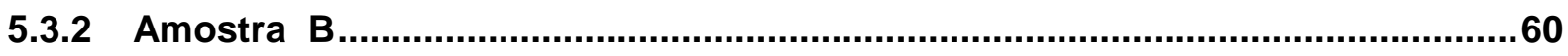

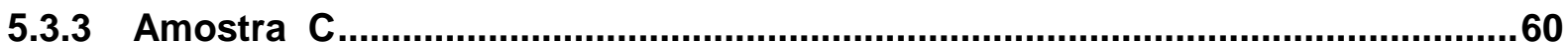

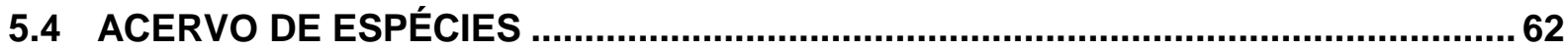

5.5 ENSAIOS 


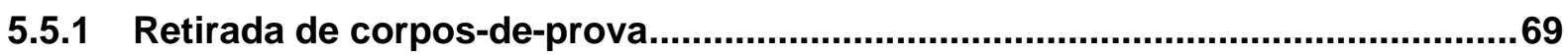

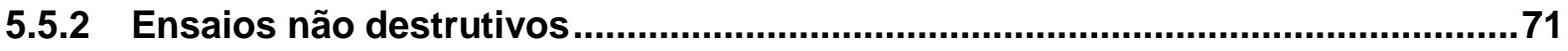

5.5.2.1 Medição do teor de umidade da madeira ….............................................. 71

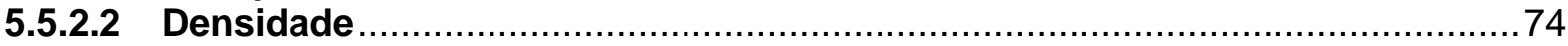

5.5.2.3 Determinação da velocidade ultrassônica ................................................ 76

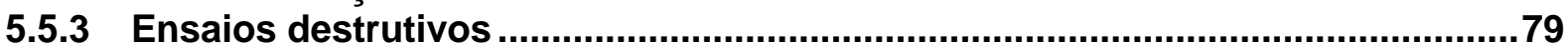

5.5.3.1 Compressão

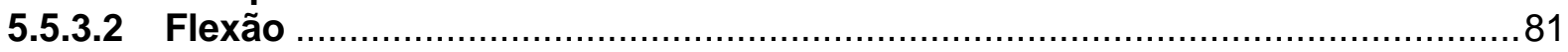

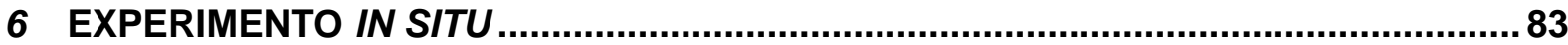

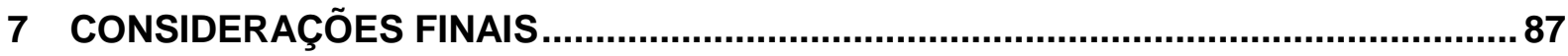

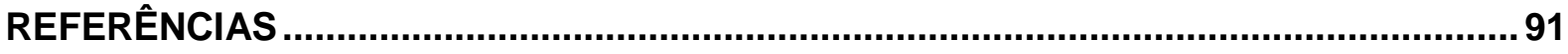

Apêndice A - Resultados dos ensaios de ultrassom ....................................96

Apêndice B - Resultados dos ensaios destrutivos .........................................99 


\section{INTRODUÇÃO}

"Madeira de lei" foi a primeira denominação utilizada no Brasil para qualificar as madeiras, que por sua resistência, são empregadas na construção de residências, navios e barcos (LEMOS, 1989). A expressão apesar de ser muito conhecida, não possui definição técnica, pois teve sua origem numa legislação conservacionista econômica lançada pela Coroa portuguesa em meados do século XVII, que procurava monopolizar a exploração das árvores consideradas especialmente importantes para a construção naval (CABRAL, 2004). Convém lembrar que até o início do século $\mathrm{XIX}$, todos os navios eram de madeira, e todo o transporte de cargas era fluvial ou marítimo (GONZAGA, 2006).

A partir de então, os conhecimentos sobre as madeiras brasileiras foram se aprimorando, passando de classificações empíricas até os atuais conhecimentos acerca das suas características físicas, mecânicas, químicas e biológicas. Já não cabe mais a denominação de "madeira de lei" ou de "madeira branca" para distinguir a madeira de boa ou de má qualidade. As madeiras são definidas pela família, gênero, espécie e pelas suas características físicas e propriedades mecânicas.

O Brasil é conhecido mundialmente pela sua biodiversidade vegetal e uma prova disso são as mais de 4 mil espécies de árvores com cerca de 15 mil nomes populares identificadas pelo Instituto Brasileiro do Meio Ambiente e dos Recursos Naturais Renováveis (IBAMA) e publicadas no "Catálogo de Árvores do Brasil" (CAMARGOS, 2002).

Estes fatos vêm demonstrar a importância que a madeira tem na formação cultural e econômica do Brasil e justificar o seu uso abundante e diversificado na construção civil, erigindo grande parte do patrimônio histórico e da identidade cultural brasileira.

$\mathrm{Na}$ condição de material de construção, a madeira incorpora todo um conjunto de características técnicas, econômicas e estéticas que dificilmente se encontram em outro material existente. É um material potencialmente durável em condições de ambiente favoráveis, porém, sob certas condições, torna-se um material vulnerável ao ataque de fungos, insetos e possível degradação química (ICOMOS, 1999). 
Esta vulnerabilidade pode ser verificada em diversas edificações do patrimônio histórico, o que a torna uma ameaça latente à preservação do legado técnico e cultural de diversas cidades brasileiras.

Entre os meses de fevereiro de 2009 e janeiro de 2010, foram noticiados ao menos dois casos de arruinamento de edifícios tombados, um deles foi o desmoronamento de diversas residências construídas no século XIX na cidade de São Luiz do Paraitinga (Foto 1), e outro foi a queda da Igreja de São Benedito na cidade de Cravinhos (Foto 2), ambos os casos no Estado de São Paulo. As duas cidades foram visitadas para reunir material de investigação e pesquisa prática para este trabalho.

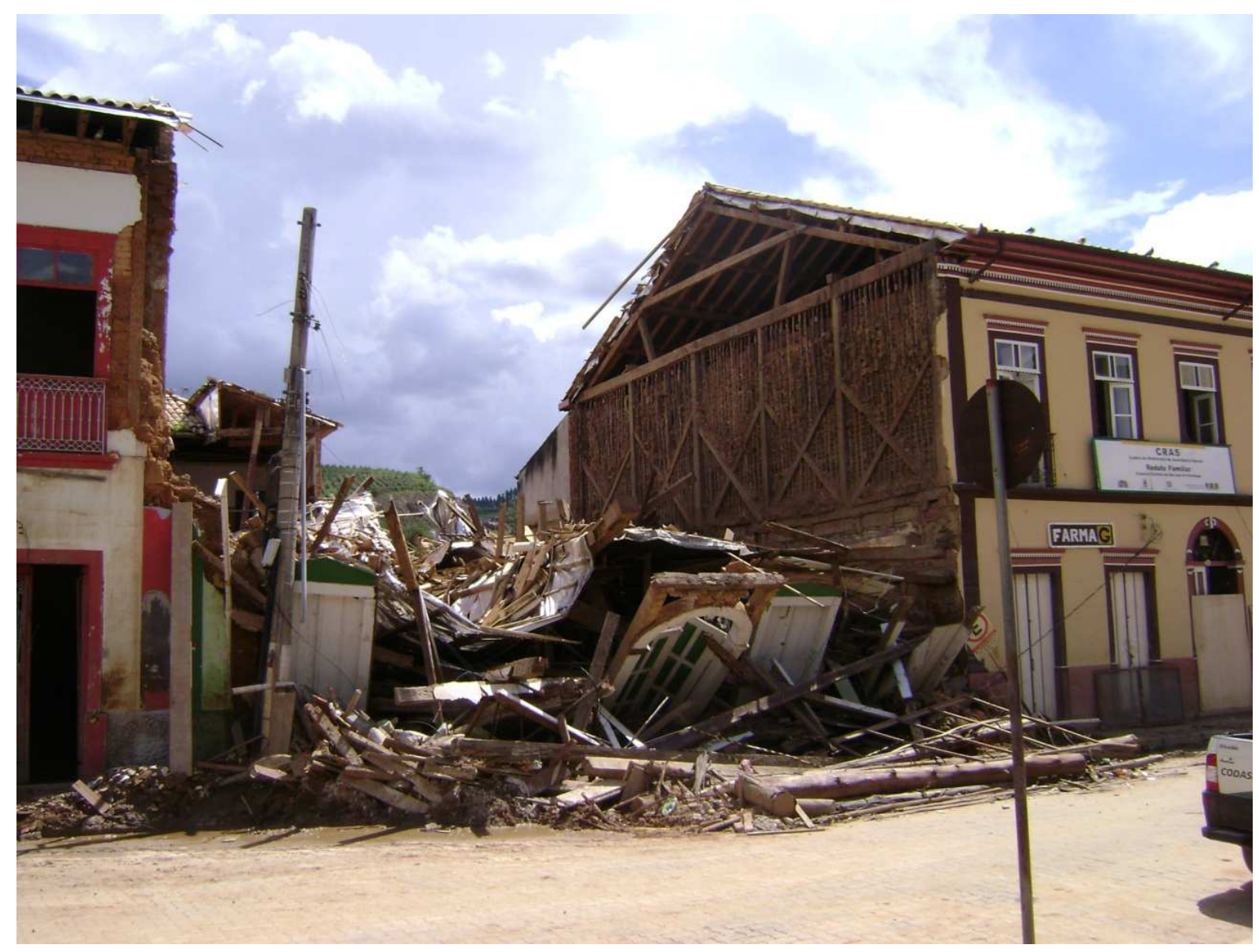

Foto 1 - Casarão desmoronado durante a enchente do dia 01 de janeiro de 2010, em São Luiz do Paraitinga, o qual apresentava presença de cupins e fungos nas peças estruturais de madeira do pau-a-pique. 


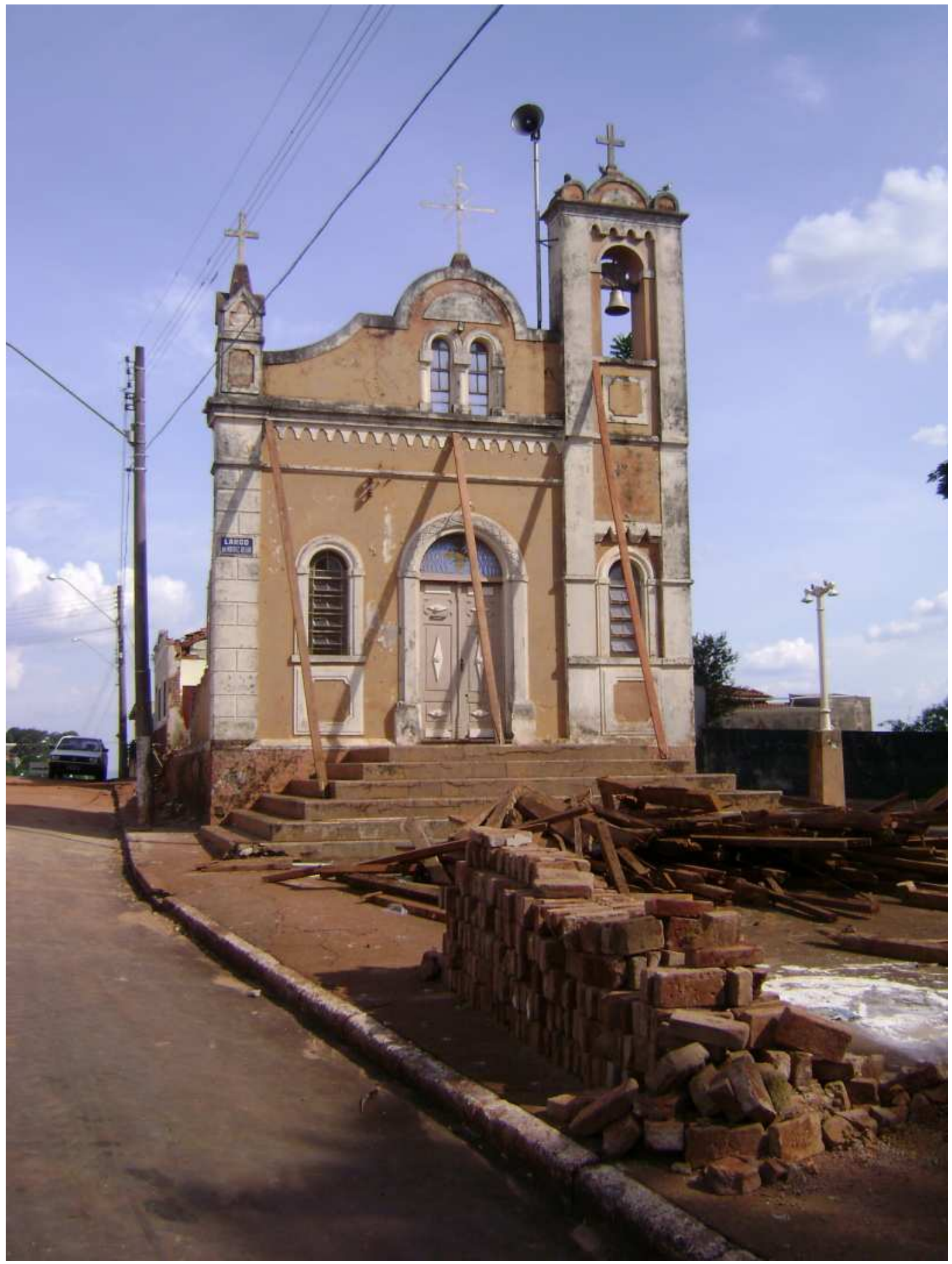

Foto 2 - Igreja de São Benedito no município de Cravinhos, desmoronada após período de fortes chuvas, no dia 25 de fevereiro de 2009. Construída em 1888, foi a primeira igreja matriz da cidade e, portanto era chamada pelos moradores locais de Matriz Velha. Foi tombada como patrimônio histórico pelo município em 1985. 
Uma construção histórica possui valor intangível associado à identidade cultural daqueles que a construíram, dos que viveram ou vivem ali, e dos indivíduos que passam periodicamente por ela. A perda dessa construção da memória histórica representa, portanto, um enorme prejuízo para a comunidade ou mesmo para a humanidade.

Segundo o documento editado pelo Centro de Estudos e Pesquisa de Desastres da Defesa Civil do Estado do Rio de Janeiro, na teoria, a perda do patrimônio histórico, cultural e artístico é considerado um desastre. Desastre, na definição do referido documento, pode ser um fenômeno isolado como um terremoto com seu epicentro numa cidade, uma chuva excepcionalmente forte numa área alagável com construções frágeis ou um fenômeno prolongado e continuado que aos poucos gera danos, prejuízos ou vítimas além daqueles que são parte da rotina da cidade. Nesse mesmo patamar, a ruína de edifícios históricos além de causar a deterioração do tecido urbano, afeta também a sociedade psicológica e moralmente, trazendo conseqüências desastrosas para a cidade (RIZZO, 2009).

No cenário internacional, a preservação das edificações é regida pela Carta de Veneza e pela Carta Internacional do Restauro, publicados em 1964. Estes documentos representam um consenso mundial sobre a necessidade da preservação das estruturas do patrimônio histórico a partir de uma abordagem mais criteriosa sobre a ação do restauro.

Mais recente, datada de 1975, é a formação do Comitê Internacional de Madeira do Conselho Internacional de Monumentos e Sítios (IIWC), considerado um importante passo do movimento mundial que preza a preservação das estruturas, em particular, as de madeira. Porém, somente no ano de 1999, foi lançado o documento intitulado "Princípios para a preservação de estruturas de madeira históricas", durante a $12^{\circ}$ Assembléia Geral no México da UNESCO. Este documento é base para a conservação de estruturas em madeira explicitando claramente a necessidade da realização de diagnósticos exaustivos e rigorosos das condições e causas de deterioração e degradação das estruturas de madeira, os quais devem anteceder qualquer intervenção para conservação ou restauração. Segundo o documento, tal diagnóstico deve ser baseado em provas documentais, 
análise e inspeção física, e, se necessário, em medições das condições físicas e métodos de ensaios não-destrutivos.

Neste contexto, entende-se que as estruturas históricas em madeira fazem referência a todo tipo de construção ou edifício feito em madeira, total ou parcialmente, que tenha um significado cultural ou seja parte de um conjunto histórico (ICOMOS, 1999).

Está no Código de Ética do Restaurador que conservar e restaurar obras do patrimônio histórico, artístico e cultural é uma profissão que requer de quem a ela se dedica extensa cultura, treinamento e aptidões especiais (APCR, 2010).

Ainda segundo o Código de Ética, entende-se por preservação de modo abrangente, todas as ações que visam retardar a deterioração e possibilitar o pleno uso dos bens culturais. Conservação-restauração seria o conjunto de práticas específicas, destinadas a estabilizar o bem cultural sob a forma física em que se encontra, ou, no máximo, recuperando os elementos que o tornem compreensível e utilizável, caso tenha deixado de sê-lo. Por conservação preventiva se designa o conjunto de ações não-interventivas que visam prevenir e/ou retardar os danos sofridos, minimizando o processo de degradação dos bens culturais (APCR, 2010).

Considerando que neste cenário do patrimônio histórico, há o consenso de que a integridade física das edificações está principalmente relacionada com suas estruturas e que há de se respeitar o requisito da mínima intervenção, tem-se, portanto, que encontrar um método para a avaliação da qualidade da madeira de maneira rápida, precisa, e que não the provoque danos, se aplica à restauração e à conservação dos bens imóveis. Este método é chamado de ensaio não destrutivo, ou simplesmente END.

Ensaios não destrutivos têm sido desenvolvidos para a caracterização de diversos materiais e podem desempenhar vários papéis importantes na investigação de estruturas históricas. Uma definição para os ensaios não-destrutivos, dada por TANASOIU (2002), é a tecnologia capaz de identificar características físicas e mecânicas ou defeitos em uma peça de material ou de estrutura, sem alterar suas qualidades finais de uso. Tal definição por si já justifica os benefícios da aplicação na avaliação de qualquer edificação que esteja em serviço, como no caso do patrimônio histórico. Outras qualificações que serão explicitadas no capítulo 4, o qual 
apresenta o método do ultrassom, são a portabilidade, a confiabilidade dos resultados e a reprodutibilidade do método, além do baixo custo dos equipamentos se comparados com equipamentos que se utilizam de outras radiações, a exemplo do raios- $X$.

De forma geral, a tecnologia de análise não-destrutiva pode ser baseada em métodos tradicionais que não requerem equipamentos sofisticados, ou baseada em tecnologias que se utilizam de fenômenos físicos, para respostas quantitativas ou qualitativas.

Os métodos tradicionais e também os mais difundidos são a observação visual e a prospecção por punção. Este último nada mais é que o uso de um instrumento pontiagudo para verificar a presença de degradação da madeira.

Em relação aos métodos considerados não tradicionais de ensaios não destrutivos, Livingstone (2001) afirma que são diversas as tecnologias que se utilizam das respostas aos principais fenômenos físicos da matéria, os quais são o som, a radiação penetrante, o eletromagnetismo e a óptica

Entre as técnicas não destrutivas consideradas não tradicionais e atualmente disponíveis para a madeira estão: o uso de raios- $X$, análise química, perfuração controlada, propagação de ondas, emissão acústica, termografia, busca com cães e penetração ao impacto, porém a interação eficaz no diagnóstico é obtida pela interação das técnicas tradicionais e não tradicionais (ROSS, 2000 e VALLE et al., 2004).

A tecnologia do ultrassom tem sido apresentada por diversos autores como um procedimento eficaz para determinar as propriedades mecânicas da madeira, validada por meio da comparação com resultados obtidos em ensaios destrutivos.

O ultrassom é caracterizado por freqüências acima de $20.000 \mathrm{~Hz}$. Entre as vantagens de sua utilização, vale destacar o baixo custo de aquisição do equipamento se comparado ao das máquinas de classificação automática de peças de madeira, e o treinamento relativamente simples da mão-de-obra para utilização do equipamento (OLIVEIRA et al., 2002).

No Brasil, cabe destacar alguns grupos de trabalho dedicados à pesquisa da tecnologia ultrassônica aplicada ao diagnóstico de patologias e avaliação de peças de madeira. Um deles é o Grupo Interdisciplinar de Estruturas em Madeira (GIEM) 
da Universidade Federal de Santa Catarina que utiliza o ultrassom na avaliação da sanidade biológica da madeira para o diagnóstico de patologias em edificações do patrimônio histórico. A Faculdade de Engenharia Agrícola da UNICAMP sob orientação da Prof. Dra. Raquel Gonçalves também utiliza o ultrassom, inclusive para classificação de postes de madeira para eletrificação.

Neste contexto, o objetivo desta pesquisa é avaliar umas metodologia para estimar a resistência de peças estruturais de madeira de peroba-rosa por método não destrutivo utilizando emissão de ondas de ultrassom, para orientar projetos de restauro de estruturas de madeira do patrimônio histórico, onde de acordo com os critérios da restauração, a avaliação por métodos destrutivos não são recomendados.

Trata-se de uma pesquisa aplicada que se encontra no limiar entre o empírico e a tecnologia, pois trata de estruturas construídas pelo saber fazer, ou seja, edificações construídas pela técnica e avaliadas por tecnologia não destrutiva.

Dada a abrangência do tema, que requer conhecimentos nas diversas ciências, têm-se como objetivos específicos ou complementares, os estudos acerca da anatomia do lenho; das técnicas construtivas; das características físicas e mecânicas da madeira; das patologias que afetam a madeira, dos defeitos naturais e dos defeitos decorrentes do processamento do material, das ações da natureza e do homem que afetam a madeira; identificando como atuam cada um destes fatores e como eles interferem na vida útil da madeira.

A pesquisa que resultou na metodologia aqui proposta oferece subsídios teóricos e práticos para todos os profissionais que se dedicam ao restauro e à conservação de edificações com peças de madeira estruturais, principalmente àquelas do patrimônio histórico. Visa preencher uma lacuna que os restauradores encontram quando tem de orientar seus trabalhos de conservação de estruturas históricas de madeira, dando subsídio para a verificação da resistência mecânica das peças estruturais por meio de método não destrutivo utilizando emissão de ondas de ultrassom.

No próximo capítulo é apresentado o uso da madeira na arquitetura do Brasil como forma de ambientar a aplicação desta metodologia, apresentando as principais técnicas construtivas que se utilizam da madeira e as principais espécies utilizadas. 
Também é apresentada uma breve abordagem com dados e fatos que ocorreram nos últimos três anos que ilustram o estado atual do patrimônio histórico brasileiro. $\mathrm{Na}$ sequência, são apresentados os requisitos para formação e atuação dos profissionais do restauro.

O terceiro capítulo apresenta a madeira como material de construção. As principais características físicas e mecânicas da madeira são apresentadas para esclarecer as peculiaridades do material ortotrópico e higroscópico que é objeto deste trabalho e como interferem na atenuação da onda de ultrassom. Também são apresentados os principais agentes que afetam e causam danos à madeira, os quais são ilustrados com imagens práticas de algumas patologias reconhecidas em edificações tombadas do patrimônio histórico.

O capítulo 4 é uma revisão bibliográfica sobre o uso do ultrassom, os avanços da tecnologia ultrassônica e as vantagens de seu uso como método não destrutivo.

O capítulo 5 apresenta a seleção das amostras de madeira e os ensaios com o uso de ultrassom em laboratório com três amostras de peroba-rosa selecionadas criteriosamente, sendo que os resultados foram comparados aos resultados de ensaios destrutivos realizados nos mesmos corpos de prova.

O capítulo 6 apresenta as discussões acerca dos ensaios e do uso do ultrassom, e o capítulo 7 apresenta as considerações finais. 


\section{O USO DA MADEIRA NA ARQUITETURA DO BRASIL}

Embora Lemos (1989) afirme que ainda está para ser escrita a história do uso da madeira nas construções brasileiras, através de registros de vários autores é possível traçar uma linha do tempo identificando os principais períodos da história e o papel da madeira em cada um deles.

Os primeiros exemplares nativos que se utilizaram da madeira são as habitações indígenas, as quais apesar de serem primitivas, atendiam perfeitamente às necessidades de seus usuários e às exigências climáticas (GARCIA et al., 1987).

La Pastina Filho (2005) relata que em suas primeiras construções no Brasil, no século $\mathrm{XVI}$, os colonizadores portugueses adotaram as soluções construtivas tradicionalmente usadas pelos indígenas, como as paliçadas de madeira e as coberturas com folhas ou fibras vegetais, assimilando também hábitos alimentares e outros, indispensáveis a sua sobrevivência no território recém conquistado (LA PASTINA FILHO, 2005).

Ainda no século $\mathrm{XVI}$, aos poucos os portugueses buscaram reconstituir, no novo território, os padrões arquitetônicos de sua cultura, caracterizada por edificações de alvenaria de pedra e cal ou taipa de pilão cobertas com telha cerâmicas, conforme 0 modelo tradicional utilizado na Península Ibérica (LA PASTINA FILHO, 2005).

A chegada dos colonizadores introduziu novas técnicas construtivas e tradições culturais na construção civil brasileira (LEMOS, 1989). Nesse período de intensa atividade mercantilista, a madeira ganhou um papel de destaque tornando-se 0 primeiro produto de exportação do país. Sendo, inclusive, atribuído o nome da madeira que produz os pigmentos vermelhos exportados para o mundo, o PauBrasil, de nome cientifico Caesalpinia echinata (AURICCHIO, 2009), ao território descoberto no ano de 1501.

Lemos (1989) relata que no período colonial a madeira era freqüentemente utilizada sem critérios técnicos, sem se cogitar de seções mínimas apropriadas ou escolha racional das espécies. A classificação das madeiras era feita empiricamente, ou seja, eram enterrados segmentos de madeira para verificar se eram resistentes à 
umidade e mergulhadas na água para ver se afundavam. As madeiras consideradas "boas" para estrutura eram aquelas que resistiam bem à umidade, que possuíam grande resistência à flexão porque eram "duras", de talhe difícil, pesadas, e que resistiam ao cupim, à broca e ao caruncho. Dentro dos critérios vigentes à época, as árvores eram derrubadas, praticamente a esmo na floresta, na lua certa ${ }^{1}$ e as peças falquejadas recebiam dimensões exageradas por garantia, mesmo porque não havia problemas de custo, nem de disponibilidade da matéria prima. A canela preta (Acrodicridium sp), a peroba (nome popular: peroba de campos, Paratecoma peroba) e a urucurana (Hieronyma alchorneoides) eram consideradas "madeiras de lei", próprias para a construção de estruturas de piso.

É comum encontrar em uma mesma edificação desse período colonial, peças estruturais de grandes dimensões de diversas espécies de madeira, inclusive em componentes com a mesma função estrutural. Estas peças eram trabalhadas com instrumentos rudimentares, lavradas a machadinha.

Até o século $\mathrm{XIX}$, as técnicas construtivas que mais se difundiram no território brasileiro eram a taipa de pilão, o pau a pique e o adobe (LEMOS, 1989; SAIA, 1978).

O uso da taipa e do pau-a-pique no Brasil se estendeu até final do século XIX. Toledo (2007) descreve a São Paulo do final do século XIX, como uma cidade de barro, onde predominavam as construções de taipa e as ruas sem calçamento de barro pisado, com feição colonial.

A taipa de pilão é uma técnica construtiva que utiliza fôrmas de madeira e solo apiloado, conforme é apresentado no esquema da figura 1. O uso da terra na construção das paredes de taipa requeria uma série de detalhes construtivos para que estas pudessem exercer sua função como vedação da edificação de forma autoportante. São eles, a construção de beirais largos de cobertura para proteger as paredes do intemperismo; o alargamento das paredes para compensar a baixa resistência à compressão da terra apiloada; e, o uso de esteios ou pilares e vergas de madeira para estruturar as aberturas (portas e janelas).

\footnotetext{
A importância da fase da lua no corte da madeira se justifica por um fator físico, de influência da lua sobre os líquidos. Com a lua cheia, uma quantidade maior de seiva é preservada no organismo da madeira, dando-lhe uma qualidade superior e menos ressecada do que aquela tirada em outro período. (http://www.museunacionaldomar.com.br/estrutura/bahia.htm)
} 


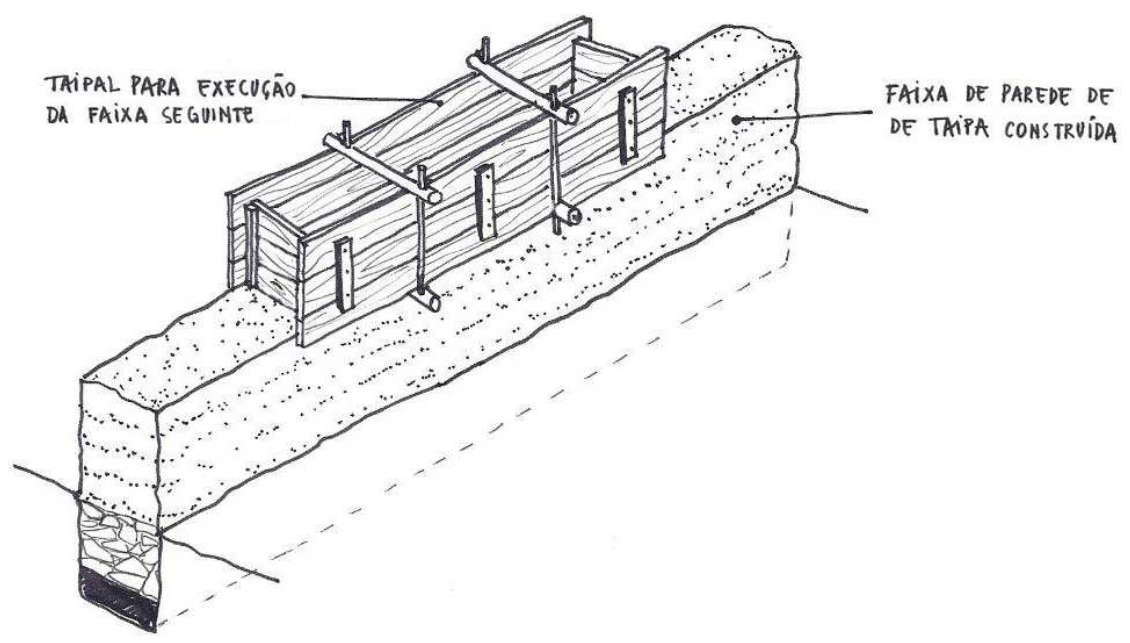

Figura 1 - Esquema de execução de uma parede de taipa (adaptado de CORONA e LEMOS, 1989)

A técnica do pau-a-pique, também chamada de taipa de sopapo, era feita com peças de madeira, bambu, terra e fibras vegetais. Uma estrutura tradicional de paua-pique era constituída por vigas e pilares de madeira lavrada com seções exageradas apoiadas sobre baldrame de pedra ou solo apiloado. O nome pau-apique informava que a vedação era formada por "paus" verticais, ou seja, peças de madeira ou bambu dispostas lado a lado, travados horizontalmente por peças de madeira ou bambu formando o ripamento em cada trecho entre os pilares de madeira. A trama de paus e travas horizontais era amarrada com fibras vegetais $\mathrm{e}$ preenchida com barro de ambos os lados simultaneamente.

A figura 2 mostra o esquema de um tipo de estrutura de parede de pau-apique preenchido com barro em sobrados do centro histórico da cidade de São Luiz do Paraitinga, conforme verificado em visitas realizadas por pesquisadores do Instituto de Pesquisas Tecnológicas do Estado de São Paulo (IPT) entre os meses de janeiro e maio de 2010. A figura 3 apresenta a possível seqüência de construção dos paus e do ripamento de uma parede de pau-a-pique. 


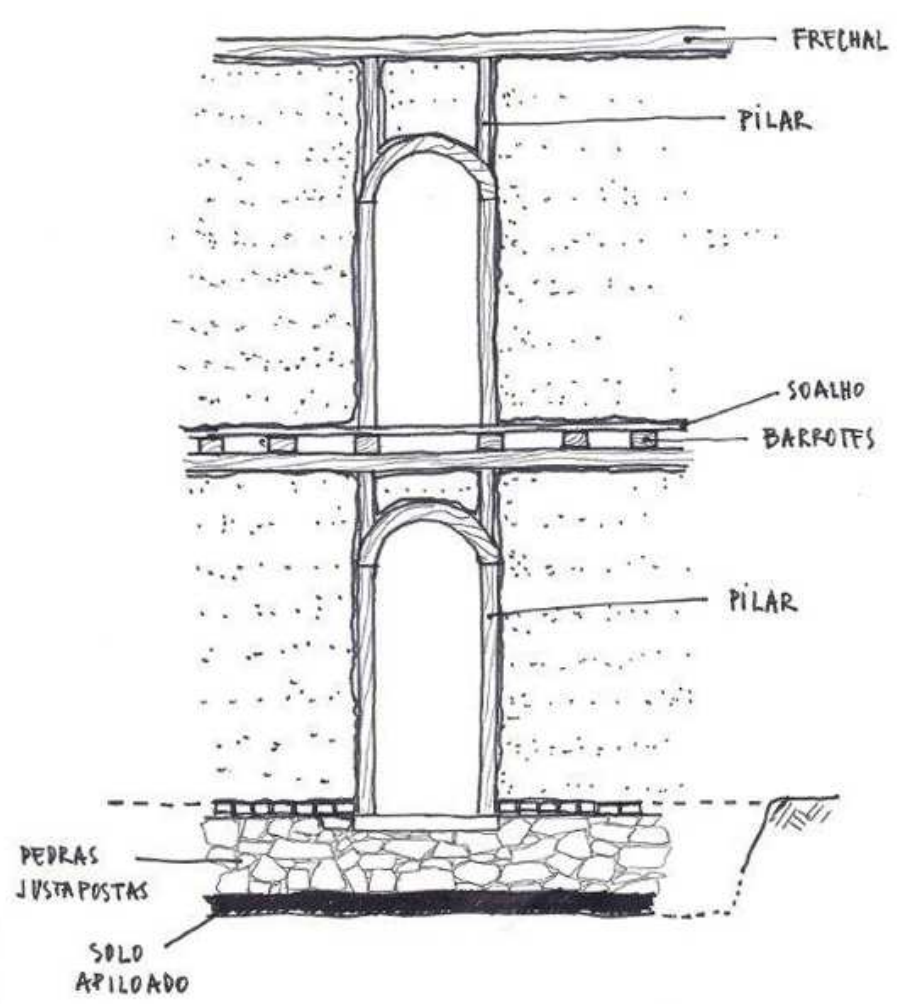

Figura 2 - Esquema estrutural das aberturas comum a diversos sobrados do século XIX com paredes de pau-a-pique, no centro histórico de São Luiz do Paraitinga.
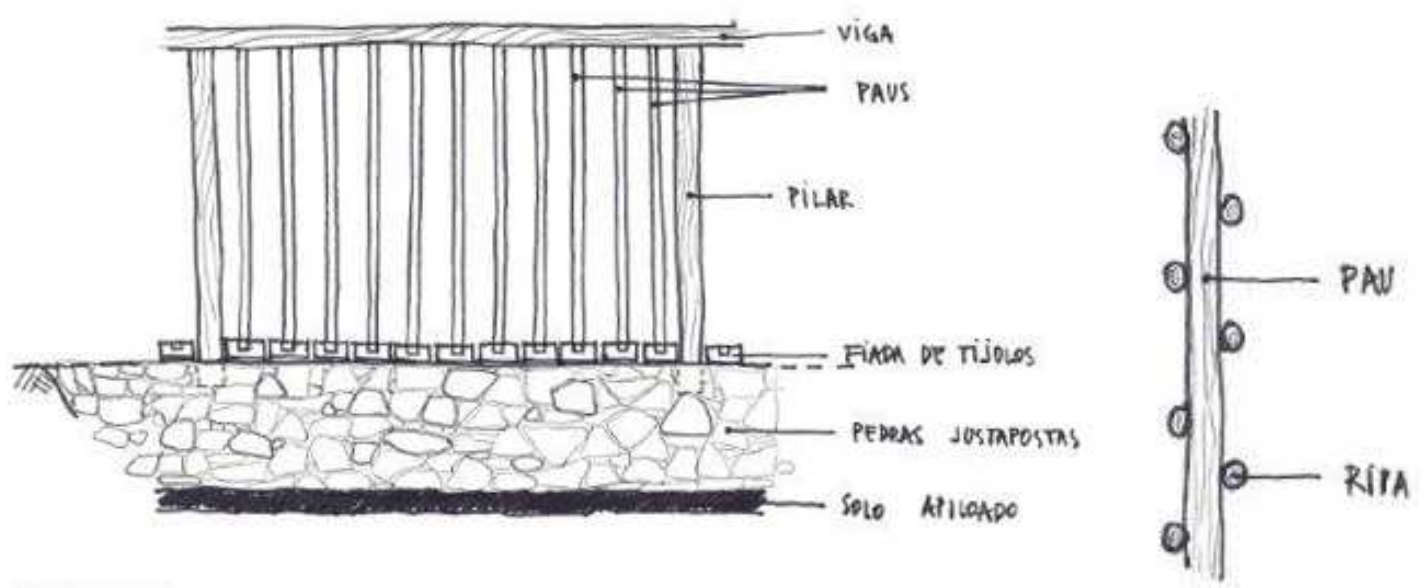

Figura 3 - À esquerda, vê-se a disposição de viga, pilares e paus de madeira apoiados sobre tijolos e pedra. Posteriormente, a essa estrutura eram incorporadas as ripas dispostas horizontalmente, conforme mostra o corte à direita. O esquema apresentado foi verificado em diversas edificações assobradadas do centro histórico de São Luiz do Paraitinga.

$\mathrm{Na}$ cidade de São Paulo do fim do século XIX, com a riqueza oriunda da economia do café e o aumento demográfico da cidade de São Paulo, deu-se início ao processo chamado de metropolização. Os construtores então, com a grande 
demanda, passaram a ter dificuldade em encontrar madeira para as suas obras. Os motivos para isso eram principalmente a distância do local de extração e a falta de qualidade da madeira comercializada. Até as peças chamadas de madeira de lei, mesmo com os altos preços praticados, não passavam por processos adequados de extração, serragem e secagem e acabavam por serem impróprias para a construção civil, pois poderiam apresentar comportamento instável devido às variações do grau de umidade do ar, empenando ou rachando. A solução mais rápida encontrada pelos construtores para contornar essa situação foi utilizar o pinho-de-riga ${ }^{2}$ (Pinus sylvestris).

O pinho-de-riga era considerado uma madeira leve, de talha fácil, comportamento dimensional estável, de alta resistência à flexão e considerado resistente ao cupim $^{3}$. Trata-se de uma espécie exótica, que entrava nos portos brasileiros como lastro de navio, embarcada no porto e capital da Letônia, Riga.

A importação do pinho-de-riga foi incrementada a partir de 1880 (ARRUDA, 2010) dominando o comércio de madeira para construções desse período, especialmente nas grandes cidades (LEMOS, 1989). Segundo Arruda (2010), a sua grande utilização no país verificou-se até a Primeira Guerra Mundial (1914-1918), quando cessou sua importação, talvez pelo fato de ter sido necessária para os ingleses na feitura de apetrechos militares.

Nos países bálticos, o pinho-de-riga era espécie abundante comercializada a baixos preços (JULAR, 2010). No Brasil, a madeira dessa espécie já era familiar dos construtores imigrantes que aqui se instalaram. Em São Paulo, há vários imóveis que apresentam componentes construtivos feitos com pinho-de-riga, como, por exemplo, nas portas do Edifício Martinelli, construído entre 1922 e 1929, e no forro do Museu da Língua Portuguesa na Estação da Luz, construída entre 1900 e 1910.

Outra transformação importante ocorrida ainda no século XIX, e que contribuiu para o rápido crescimento urbano, foi a popularização dos tijolos cerâmicos, propondo-se inclusive o abandono definitivo da taipa de pilão. Culminam

2 Embora o nome popular, pinho-de-riga, seja muito difundido na literatura, segundo Lorenzi (2003) a madeira de Pinus Sylvestris também é conhecida por pinheiro-de-riga, pinheiro-da-escócia, pinheiro-da-rússia, pinheiro-vermelho-do-báltico, pinheiro-do-norte, pinheiro-de-genebra, pinheiro-bravo, pinheiro-comum, pinheiro-silvestre, pinheiro-de-casquinha.

3 A madeira de pinho-de-riga é citada na literatura como madeira resistente a cupins, porém foram encontradas peças intensamente atacadas por cupins-de-madeira-seca na estrutura de cobertura da Basílica Menor do Bom Jesus na cidade de Tremembé, em inspeção realizada pelo IPT em 2009. O Basílica Menor do Bom Jesus foi construída em 1795 e está em processo de tombamento pelo CONDEPHAAT. 
para a difusão da técnica construtiva com tijolos a chegada dos imigrantes italianos, a construção das estradas de ferro, e a demanda por prazos e volume de obras (LEMOS, 1989).

Este rápido desenvolvimento das cidades trouxe alterações também na legislação urbana. Em São Paulo, em 1850, passaram a vigorar as posturas de caráter urbanístico arquitetônico na definição dos bairros. As prescrições que procuravam impor uma feição de urbanidade ou civilidade à cidade, proibiam a construção de ranchos ou casas de madeira e de sapé, ou cobertas com capim (SIMÕES JUNIOR, 2002), comuns das áreas rurais.

$\mathrm{O}$ abandono das técnicas construtivas em terra (taipa e pau-a-pique) e a adoção dos tijolos para a construção das casas e casarões no final do século XIX, mantiveram o status da madeira como peças estruturais principalmente em vigamentos de piso e cobertura.

Com o contínuo processo de êxodo rural e o desmatamento para a construção das novas cidades, já no começo do século XX, deu-se preferência às espécies de madeira conhecidas e abundantes nas regiões sul e sudeste. Esta demanda recaiu sobre as espécies nativas como o pinho-do-paraná (Araucaria angustifolia) e a peroba-rosa (Aspidosperma polyneuron), o que veio causar ao longo das décadas de exploração a conseqüente escassez dessas espécies (ZENID, 2009).

Nas paisagens paranaenses até metade do século $X X$, o uso da madeira foi marcante tanto pelas construções em pinho-do-paraná no sul, centro sul e oeste, como pelas de peroba-rosa no norte, noroeste e parte do oeste e sudoeste do estado (ZANI, 2001).

Gonzaga (2006) descreve que a peroba-rosa era encontrada em qualquer construção feita até a metade do século XX, sendo inclusive adotada como madeira de referência para calculistas e livros técnicos, cujos valores e propriedades a madeira disponível deveria ser comparada.

Até $\mathrm{o}$ advento de outros materiais processados industrialmente, como por exemplo, o aço e o concreto, a madeira foi amplamente utilizada nas estruturas de casas, sobrados e edifícios públicos, os quais guardam entre suas paredes 0 importante legado técnico e empírico de diversas gerações de construtores e 
carpinteiros. As fotos 3 a 7 ilustram o uso da madeira em estruturas de piso, parede e cobertura de construções datadas do século XIX e tombadas ou em processo de tombamento como patrimônio histórico pelo Conselho de Defesa do Patrimônio Histórico, Arqueológico, Artístico e Turístico do Estado de São Paulo (CONDEPHAAT)
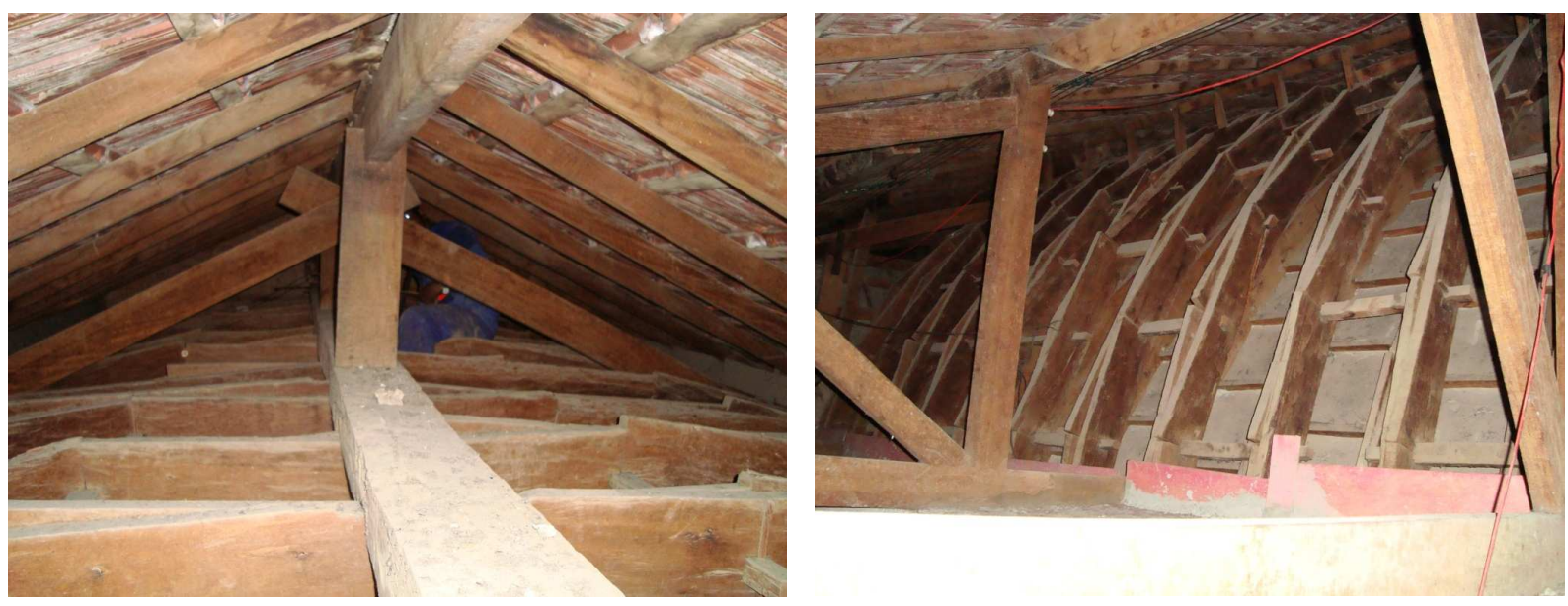

Fotos 3 e 4 - Estrutura de cobertura e cambotas da Basílica do Bom Jesus na cidade de Tremembé, Vale do Paraíba, foi construída em 1795 e se encontra em processo de tombamento.

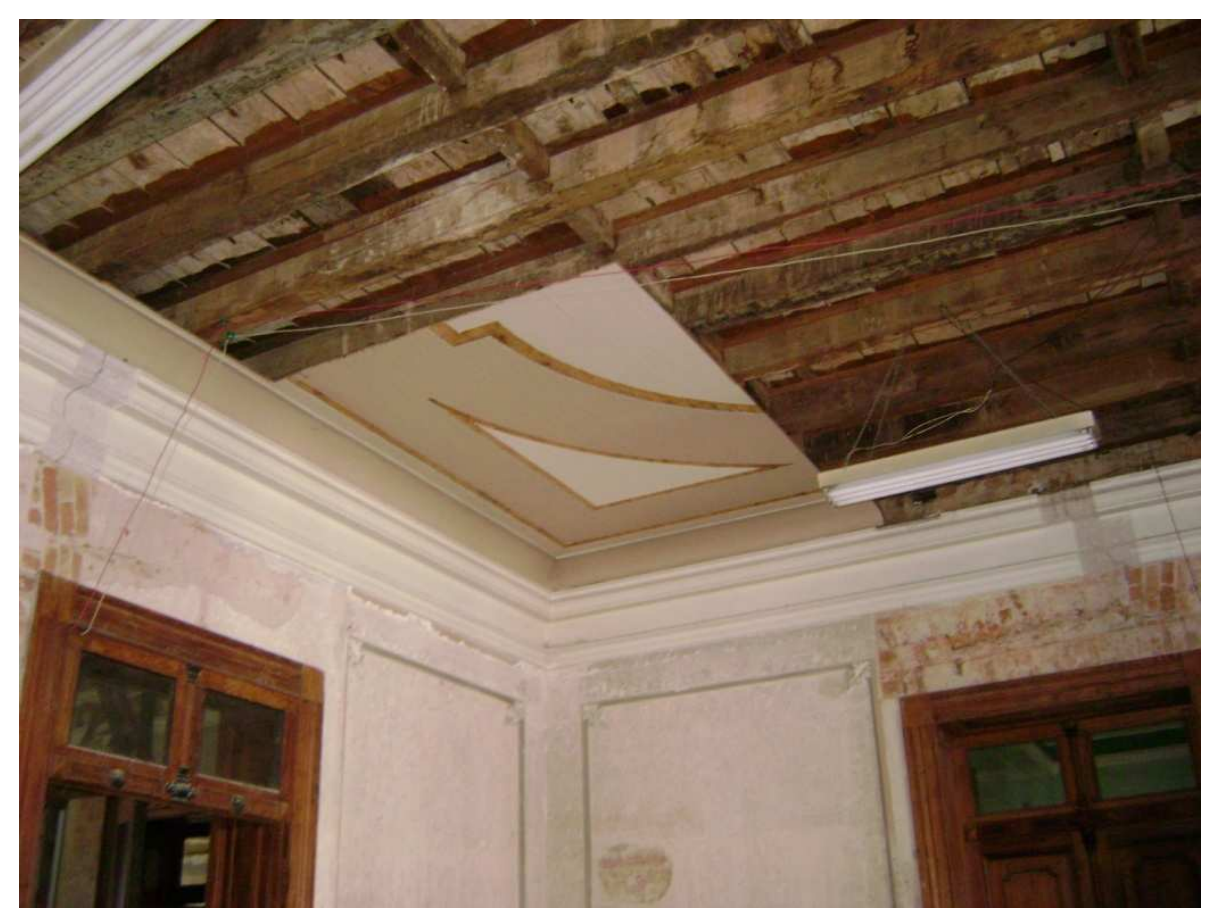

Foto 5 - Uso de vigas de madeira, forro, assoalho e batentes em madeira no Palacete 10 de Julho em Pindamonhangaba, construído na segunda metade do século XIX para ser residência dos barões do café no Vale do Paraíba. Foi tombado pelo CONDEPHAAT em 1969. 


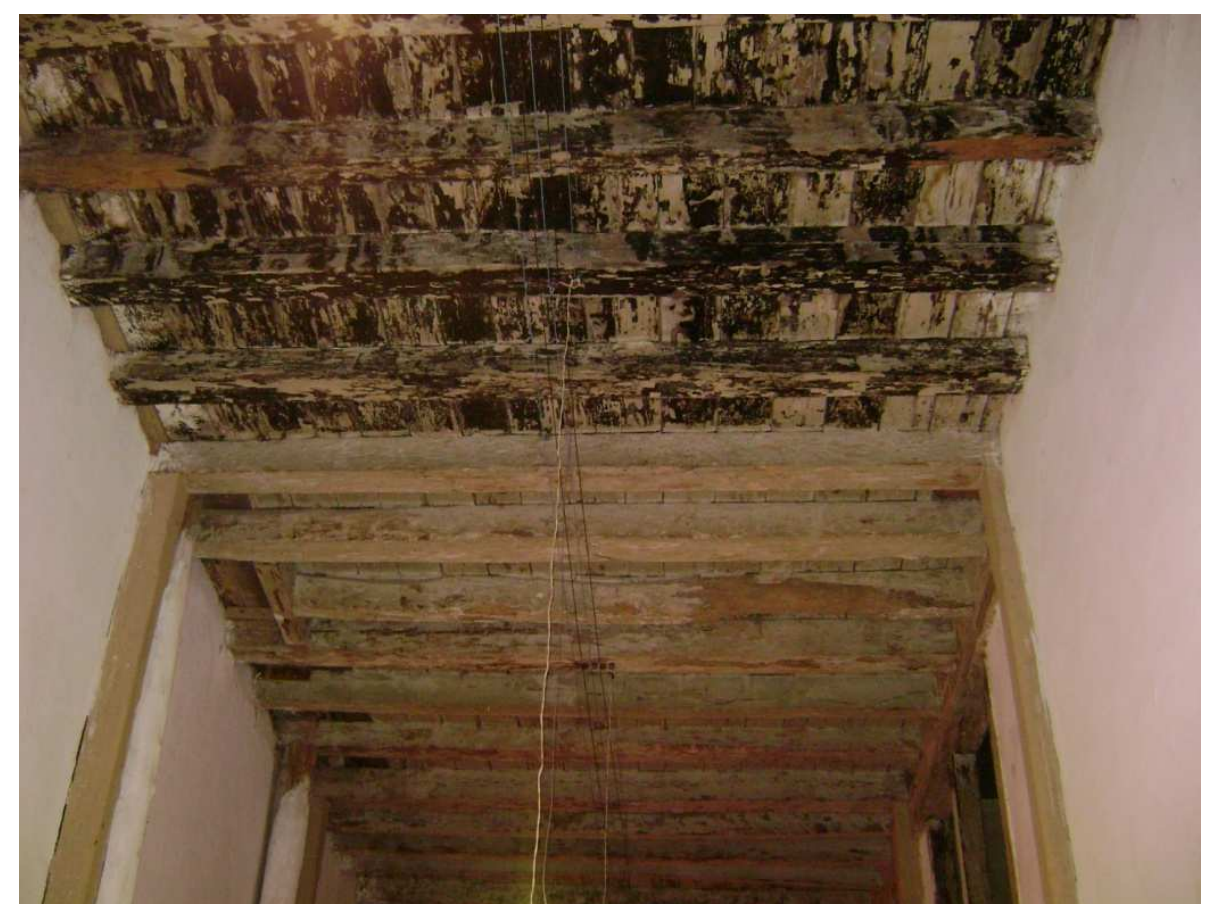

Foto 6 - Vigas, pilares e assoalho de madeira do Sobrado Vallim em Bananal/SP, construído por volta de 1850, constitui um exemplar urbano típico de viver dos fazendeiros de café. Foi tombado em 1972 pelo CONDEPHAAT.

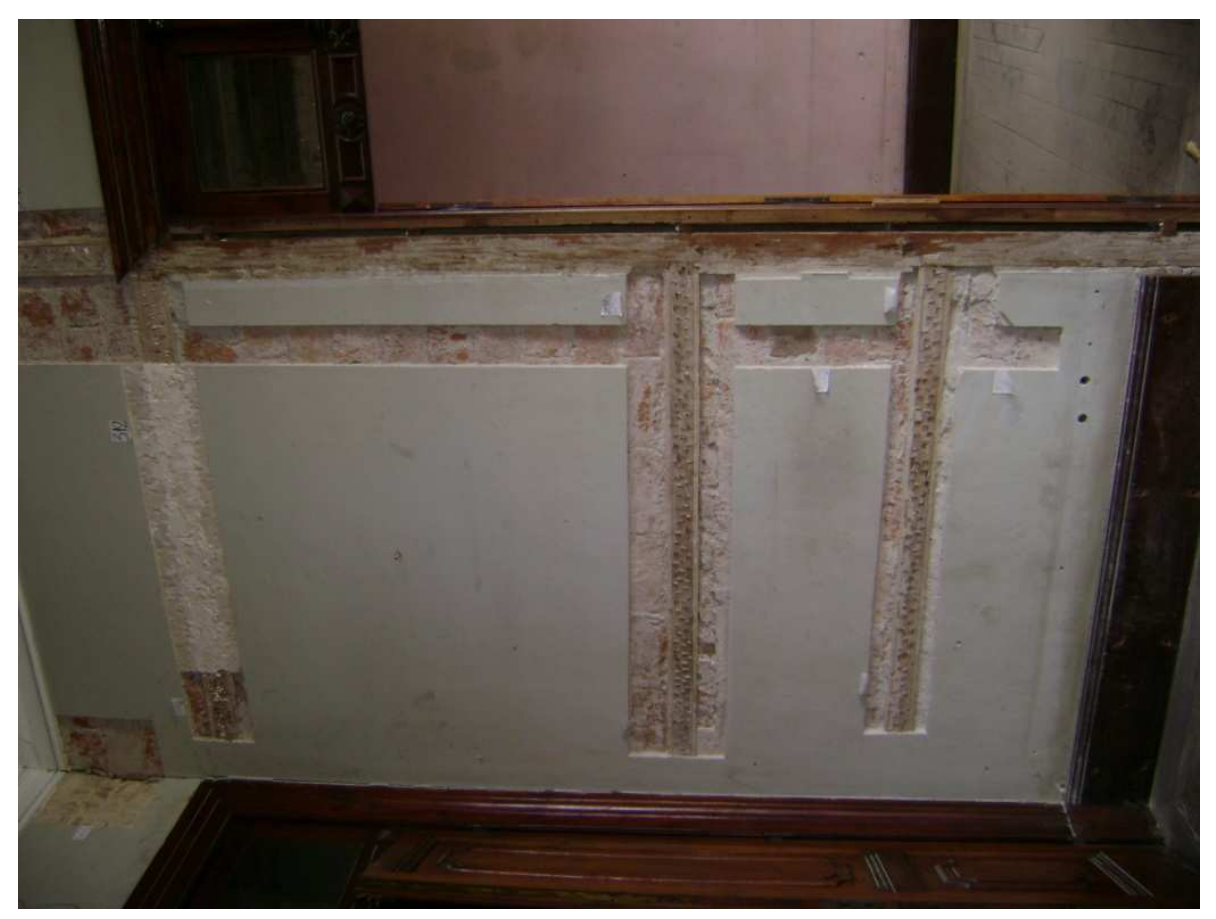

Foto 7 - Janelas de prospecção de peças de madeira em parede de alvenaria de tijolos no Palacete 10 de Julho na cidade de Pindamonhangaba, construída na segunda metade do século XIX. Está em processo de restauro. 


\subsection{ABORDAGEM SOBRE O ESTADO ATUAL DE CONSERVAÇÃO DO PATRIMÔNIO HISTÓRICO BRASILEIRO}

O termo patrimônio histórico cultural se refere aos bens imóveis, móveis, naturais e arqueológicos que tem valor significativo e representação na história e na identidade da sociedade. Os bens intangíveis foram mais recentemente incorporados ao conjunto de objetos do patrimônio histórico, na forma de expressões, conhecimentos, práticas, artefatos, lugares e grupos.

Por tombamento se entende o instituto jurídico através do qual o poder público determina que certos bens culturais sejam objetos de proteção especial (IPHAN, 2009). Desta forma, um imóvel tombado como patrimônio histórico, não pode ser demolido, nem mesmo reformado, deve ser conservado ou restaurado seguindo normas e requisitos específicos que possibilitem preservar sua legitimidade histórica e artística.

O termo "tombamento" é uma herança lingüística portuguesa e que remete à Torre do Tombo, localizada em Portugal, onde eram arquivados os registros patrimoniais (CHOAY, 2000).

Trata-se de um instrumento do poder público, baseado em ações de teor técnico, administrativo e jurídico, com o objetivo de garantir a preservação de bens de valor histórico, cultural, arquitetônico, ambiental, paisagístico e urbano, de modo que não venham a ser demolidos, destruídos, mutilados ou descaracterizados. $O$ tombamento não significa um confisco da propriedade, e o bem pode ser vendido ou alugado como qualquer outro. O imóvel também pode mudar de uso, e mesmo obras de reforma ou restauro são aceitas, desde que autorizadas pelo órgão de preservação responsável pelo seu tombamento (PRESERVASP, 2009).

No Brasil, o tombamento de um imóvel pode ser dado pela instância federal, estadual ou municipal, ou por todas.

Nos últimos anos, verifica-se um crescente interesse das pessoas em conhecer os aspectos históricos e culturais imbricados ao patrimônio arquitetônico. Tal atitude parece ter sido encorajada a partir de uma maior compreensão do valor ou significado simbólico que passou a ser atribuído às obras edificadas do passado, 
então compreendidas como um produto cultural das sociedades ao longo dos tempos e um suporte importante para a manutenção das identidades (FUCKS, 2003).

Esse passado não precisa ser tão distante no tempo, pois há também o patrimônio histórico contemporâneo, contudo, é nas edificações construídas até meados do século XX, nas casas de taipa e pau-a-pique, que a madeira está mais presente. São, portanto, estas construções mais antigas, construídas com terra e madeira, as mais vulneráveis aos danos causados pelo tempo, pela presença de umidade, e pelo ataque de insetos e fungos.

Independente do material e técnica construtiva, os dados existentes sobre o estado de conservação das edificações históricas não passam despercebidos e instigam ações para conter a ação do tempo e dos agentes de deterioração. Um levantamento realizado nos registros do Conselho Municipal de Preservação do Patrimônio Histórico, Cultural e Ambiental da Cidade de São Paulo (CONPRESP), em janeiro de 2009, mostra que cerca de 40\% dos 1813 imóveis tombados ou em processo de tombamento de toda a cidade de São Paulo estão abandonados, destruídos ou descaracterizados. No centro da cidade, dos 1272 imóveis históricos da região, 34\% fazem parte dessa estatística. Na zona norte da cidade, $79 \%$ do patrimônio estão abandonados ou destruídos, enquanto na zona leste esse índice chega a 94\%. (O ESTADO DE SÃO PAULO, 2009)

Nesse sentido, o tombamento de um imóvel é importante para a identidade histórica de uma cidade ou região, embora isoladamente não garanta a sua salvaguarda. O destino do imóvel tombado dependerá muito dos esforços do conjunto do poder público e privado para que seja restaurada a sua integridade física e histórica.

Entre as políticas públicas recentes na esfera federal que tem como objeto as ações voltadas para o patrimônio tombado, está o Programa de Aceleração do Crescimento das Cidades Históricas do Ministério da Cultura no Brasil lançado em 28 de agosto de 2009. Este projeto prevê o destino de $\mathrm{R} \$ 150$ milhões por ano, para obras de requalificação urbanística, infra-estrutura urbana, financiamento para recuperação de imóveis privados, restauro de monumentos e promoções do patrimônio cultural em 124 cidades históricas (O ESTADO DE SÃO PAULO, 2009). 
Conforme informado pelo IPHAN (2010), a formatação do PAC Cidades Históricas é fruto da experiência realizada pelo próprio instituto junto ao Programa Monumenta que representou, pela primeira vez, o desafio de integrar ações de preservação do patrimônio com estratégias de desenvolvimento local. Este programa está em fase de conclusão, pois o investimento do Banco Interamericano de Desenvolvimento (BID) encerrou-se no final de 2009, e as obras têm até o fim de 2010 para serem concluídas.

Um dos principais objetivos do PAC das Cidades Históricas é o desenvolvimento da infra-estrutura das cidades tombadas ou em processo de tombamento, como é o caso da cidade de São Luiz do Paraitinga. A adesão desta cidade, em março de 2010, foi feita em caráter emergencial, dada a gravidade da situação que sobreveio à enchente do início de 2010 (RECONSTRUÇÃO, 2010).

Ações como estas são importantes, pois incentivam as pesquisas e a formação de um maior número de profissionais que atuem na restauração e conservação criteriosa do patrimônio histórico.

\subsection{ATIVIDADES DO CONSERVADOR E RESTAURADOR DE BENS IMÓVEIS}

$\mathrm{Na}$ intervenção de uma estrutura de madeira em serviço, o principal desafio é saber o que tem de ser substituído ou reforçado. Nas edificações do patrimônio histórico, esta decisão cabe aos profissionais do restauro, que muitas vezes, tem prazos e recursos exíguos para decidir como deve ser o projeto executivo e a restauração.

Os antigos gregos já priorizavam a conservação de suas obras, praticando a conservação preventiva, pois faziam a seleção de materiais e técnicas para a execução de suas esculturas e pinturas. Porém, somente no século $X X$ da era moderna que os critérios e teorias sobre conservação e restauração de obras de arte são definidos, inclusive com a revisão dos procedimentos e teorias de conservação e restauração da arte contemporânea (MIGUEL, 1995). É neste período que surgem questões jurídicas na defesa do patrimônio, tais como a regulamentação da profissão de restaurador.

No Brasil, atualmente tramitam no Congresso Nacional dois projetos de lei que regulamentam o exercício da profissão de conservador-restaurador no país. 
É importante citar que a existência de ambos os projetos de lei incentiva a formação de cursos para formação de profissionais na área.

O conservador-restaurador atua em diversos tipos de bens culturais, sejam eles móveis ou imóveis, com o objetivo comum de preservar os bens culturais para benefício da atual geração e das gerações futuras. Segundo o Código de Ética do conservador-restaurador elaborado por associações atuantes na área, este profissional deve realizar diagnósticos, tratamentos de conservação e restauração dos bens culturais, a respectiva documentação de todos os procedimentos, além do estabelecimento de atividades referentes à conservação preventiva (APCR, 2010).

Baseado nas diretrizes definidas nos códigos do International Council of Museums (ICOM), do American Institute of Conservation (AIC), do European Federation of Conservator-Restorers' Organizations (ECCO) tem-se as premissas da relação do conservador-restaurador com os bens culturais, no sentido de que:

- Toda a atuação do conservador-restaurador deve ser orientada pelo absoluto respeito ao valor e significado estético e histórico, bem como à integridade física dos bens culturais que the estejam afetos.

- O conservador-restaurador deve contratar e empreender apenas os trabalhos que possa realizar com segurança, dentro dos limites de seus conhecimentos e dos equipamentos de que dispõe, a fim de não causar danos aos bens culturais, ao meio ambiente ou aos seres humanos.

- Sempre que for necessário ou adequado, o conservador-restaurador deve consultar especialistas de qualquer uma das atividades que the complementem a atuação, envolvendo-os em ampla troca de informações.

- Em qualquer situação de emergência onde um bem cultural esteja em perigo iminente, o conservador-restaurador deve dar toda a assistência possível, independentemente de sua área de especialização.

- O conservador-restaurador deve levar em consideração todos os aspectos relativos à conservação-preventiva, antes de intervir em quaisquer bens culturais e sua iniciativa deverá restringir-se apenas ao tratamento necessário. 
- O conservador-restaurador, em colaboração com outros profissionais relacionados com a salvaguarda dos bens culturais, deve levar em consideração a utilização econômica e social dos bens culturais, enquanto salvaguarda desses mesmos bens.

Neste sentido, a atuação do profissional do restauro é ampla, e deve ser baseada em cursos de formação acadêmicos, de especialização, de pós-graduação e técnicos. Assim, além dos conhecimentos específicos em sua formação, o conservador-restaurador deve receber conhecimentos básicos de História da Arte, Biologia, Química, Física, e outros, trabalhando de forma multidisciplinar.

É neste cenário, que é apresentada a pesquisa de um método não destrutivo para a avaliação de um importante legado do patrimônio histórico, as estruturas de madeira, apresentando resultados práticos fundamentados em ensaios laboratoriais para a espécie de peroba-rosa. 


\section{A MADEIRA}

O conhecimento das características físicas e das propriedades mecânicas da madeira contribui para a diversificação do uso das espécies disponíveis e possibilita o emprego das espécies mais adequadas a cada finalidade (MADY, 2000). Esta é uma das bases do uso sustentável da madeira, pois o uso intensivo e constante de determinadas espécies gera uma série de impactos negativos - sociais, ambientais e, até mesmo, econômicos (IPT, 2009).

A madeira é o material lenhoso oriundo da árvore, que têm, inevitavelmente, um elevado grau de diversidade e variabilidade em suas propriedades, além de ser suscetível a deterioração biológica e a ação do fogo. Em 1980, o IPT classificou 200 espécies brasileiras utilizadas na construção civil, naval e moveleira. Esta classificação apresenta as características anatômicas, regiões de ocorrência, resistência à biodeterioração, trabalhabilidade e propriedades mecânicas de cada espécie.

Essa diversidade e complexidade do material, porém, não deve se tornar uma barreira para seu uso, e sim se tornar um aliado de arquitetos, engenheiros, restauradores e construtores, permitindo a diversificação de usos na construção civil.

As técnicas empíricas utilizadas nas construções de taipa e pau-a-pique até o século XIX, por exemplo, buscavam conhecer qualitativamente as características físicas e as propriedades mecânicas das espécies de madeira. Eram frequentemente utilizadas as madeiras mais duras e resistentes aos insetos nas peças estruturais mais importantes da edificação.

Atualmente, as construções requerem projetos e cálculos estruturais regidos por normas. No Brasil, há a norma ABNT NBR 7190 - Projeto de estruturas de madeira, na qual são apresentadas as diretrizes de cálculo e os procedimentos de ensaio das principais características e propriedades da madeira, objetivando o dimensionamento das estruturas.

Diferentemente de outros materiais usados na construção civil, a madeira tem particularidades que devem ser consideradas em projetos e análises de estruturas. Segundo Larsten (2001) basicamente deve ser considerado que a madeira das 
estruturas não é um material manufaturado, é de origem natural e, portanto é heterogêneo; que as propriedades da madeira não variam somente entre os indivíduos (árvores), mas também na própria árvore; que as propriedades dependem do histórico da umidade ao qual a edificação foi submetida; que as propriedades mecânicas de uma peça de madeira também podem ser afetadas pelo seu histórico do carregamento; e que o material é ortotrópico e a ruptura pode ser influenciada por uma fratura frágil na tensão perpendicular à grã ${ }^{4}$.

Tais particularidades citadas por Larsten (2001) estão relacionadas com os fatores que afetam a vida útil do material, os quais podem ser divididos como fatores intrínsecos e extrínsecos ao material. Os fatores intrínsecos são aqueles relacionados ao material que não dependem de agentes externos. Enquanto os fatores extrínsecos são principalmente, os agentes externos de deterioração, podendo ser ações da natureza ou ações do homem.

Neste trabalho, em se tratando de uma pesquisa que visa entender 0 comportamento da madeira de peroba-rosa frente a emissão de ondas de ultrassom, não cabe aqui se estender sobre uma descrição das características físicas e as propriedades mecânicas da madeira. Um material importante de consulta para conhecer essas características é o livro Wood Handbook: wood as na engineering material (2010). Optou-se, então, por ater este capítulo às principais características físicas e mecânicas que são responsáveis por alterações e atenuações ${ }^{5}$ das ondas de ultrassom, com a finalizadade de balizar os estudos experimentais. Ainda neste capítulo, são apresentadas as principais patologias que afetam a vida útil da madeira.

Algumas características físicas e mecânicas da madeira são importantes de serem citadas neste trabalho, pois, a onda ultrassônica tem uma resposta diferente para cada espécie de madeira, e também respostas diferentes para peças com diferentes tipos de danos.

\footnotetext{
${ }^{4}$ A grã da madeira está relacionada com a orientação das fibras em relação ao eixo longitudinal da árvore.

${ }^{5}$ Atenução é a perda definida pela diminuição da intensidade de energia de um sinal ao propagar-se através de um meio de transmissão (EMERSON et al., 1999).
} 
No tema do ultrassom, tem-se que os mecanismos de perda ultrassônica nos sólidos são considerados mais numerosos e complexos que nos líquidos e gases (OLIVEIRA e SALES, 2000). Na madeira, os principais fatores de atenuação são o teor de umidade, a densidade, a anatomia da espécie e as características geométricas da peça (BUCUR, 2008).

\subsection{CARACTERÍSTICAS FÍSICAS E MECÂNICAS DA MADEIRA}

As principais características físicas e mecânicas da madeira que afetam o comportamento do ultrassom são apresentadas a seguir.

\subsubsection{Ortotropia}

Em uma mesma espécie de madeira, em virtude de fatores genéticos e ambientais que influenciam no crescimento das árvores, há variabilidade das características mecânicas à medida que o tecido lenhoso varia tanto na sua posição em relação ao eixo do tronco, quanto na sua localização em relação ao solo, na altura do tronco (MADY, 2000). Este fato caracteriza a anisotropia da madeira, onde as propriedades mecânicas da madeira variam segundo a direção ou plano onde são aplicados os esforços mecânicos.

Diferentemente de outros materiais manufaturados, a madeira apresenta três eixos principais, que caracterizam a ortotropia do material. A figura 4 ilustra o modelo da ortotropia em um segmento de tronco de madeira.

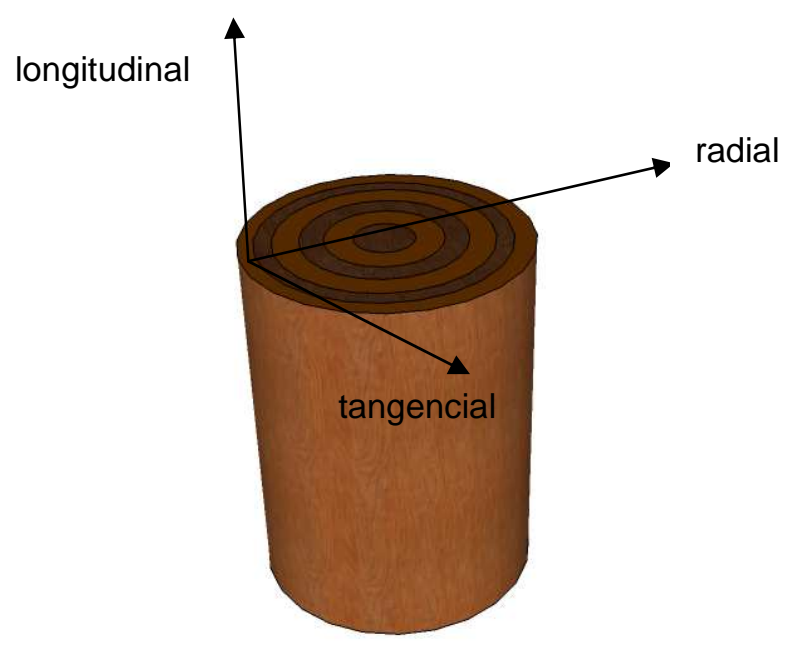

Figura 4 - Principais eixos da madeira 
Assim como variam as propriedades ao longo da direção dos elementos anatômicos no sistema axial, os mecanismos de dissipação ou atenuação de energia ultrassônica também são alterados.

Em geral, na direção longitudinal das fibras da madeira, os valores de atenuação são relativamente pequenos, enquanto os valores de velocidade são os mais altos possíveis, em razão da continuidade entre os elementos anatômicos e da alta cristalinidade das microfibrilas celulósicas (BUCUR, 2008).

Bucur (1995 apud CARRASCO e AZEVEDO JÚNIOR, 2002) observou em ensaios, que as maiores atenuações e as menores velocidades ocorrem na direção tangencial, em virtude da descontinuidade dos elementos estruturais internos do lenho ao longo da direção de propagação da onda.

Segundo Bucur (2008), dada uma freqüência ultrassônica, quando uma onda longitudinal se propaga na direção das fibras da madeira, os comprimentos de onda e os comprimentos das células são da mesma ordem de grandeza. A propagação ocorre, dessa forma, no regime de dispersão estocástico. Por outro lado, ao longo das direções radial e tangencial, os comprimentos de onda são consideravelmente maiores que as dimensões médias das células e a propagação ocorre, provavelmente, dentro do regime de dispersão de Rayleigh ${ }^{6}$.

\subsubsection{Higroscopia}

A madeira perde e absorve umidade com facilidade, o que a caracteriza como um material higroscópico.

O teor de umidade na madeira, contudo, tem forte influência na sua resistência mecânica, pois quase todas as suas propriedades mecânicas são alteradas com a saturação progressiva do tecido lenhoso (MADY, 2000).

A queda na resistência com a saturação do tecido lenhoso é explicada pelo comportamento dos principais constituintes da madeira quando absorvem água.

A madeira constitui, por natureza, um material higroscópico, que sofre inchamento ou retração com o aumento ou a diminuição da umidade, respectivamente. As propriedades físicas também são afetadas pela umidade e por ela ser um sólido ortotrópico do ponto de vista elástico. Em termos de grandeza, as

6 Dispersão de Rayleigh é o princípio da dispersão da radiação por partículas menores que seu comprimento de onda. 
retrações axiais em função da secagem da madeira são quase desprezíveis se comparadas às tangenciais que são o dobro das retrações radiais (USDA, 1999).

Quando saturada de água, a madeira torna-se um material poroso anisotrópico de duas fases: fase sólida representada pelos elementos anatômicos e fase fluída, representada pelo volume de água nos poros.

A relação entre velocidade de propagação de ondas e a umidade foi definida por Bucur (2008), que demonstrou que a velocidade diminui na medida em que o conteúdo de umidade aumenta, ao passo que a atenuação aumenta conforme aumenta o conteúdo de umidade, como apresentado no gráfico da figura 5. O máximo valor de velocidade e o mínimo valor de atenuação são obtidos quando a madeira se encontra seca.

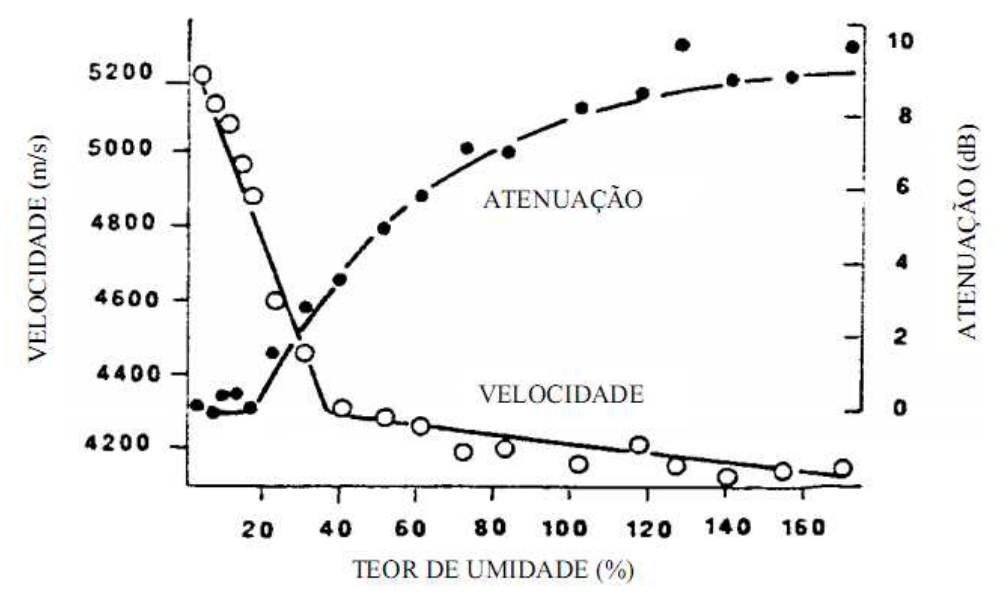

Figura 5 - Influência da umidade na velocidade de propagação da onda na direção longitudinal (adaptado de BUCUR, 2008).

Bucur (2008) observou também que ao teor de umidade menor que $18 \%$, o pulso ultrassônico é refletido pelas células da madeira, o que implica que não há a interferência da água livre na madeira.

\subsubsection{Densidade da madeira}

A densidade da madeira de uma árvore varia dentro da árvore, durante a vida da árvore e entre os indivíduos da mesma espécie.

Uma regra prática é considerar que à medida que aumenta a densidade, aumenta a resistência mecânica e durabilidade natural da madeira, em sentido inverso, diminuem a permeabilidade a soluções preservantes, acabamentos e 
trabalhabilidade. Assim, a densidade da madeira é considerada uma das propriedades mais importantes da madeira, sendo por isso considerada, um bom índice de qualidade da madeira.

Em relação ao ultrassom, Oliveira e Sales (2000) concluíram em experimentos de laboratório que há uma maior velocidade de propagação em qualquer das três direções, com o aumento da densidade em condições de umidade constante ao longo da amostra.

A densidade da madeira, assim, como a rigidez, é sensivelmente afetada pelo teor de umidade. Todavia, o efeito da umidade na rigidez é muito mais expressivo do que na densidade (BUCUR apud CARRASCO e AZEVEDO JÚNIOR, 2002).

Considerando os estudos realizados com variações de teor de umidade e densidades, tem-se que as maiores velocidades ultrassônicas são alcançadas em espécies de madeiras com estrutura anatômica homogênea e em menores teores de umidade.

Considerando que a densidade da parede celular é razoavelmente constante para todas as espécies, tem-se que é a estrutura anatômica da espécie de madeira a qual interfere na velocidade ultrassônica. No caso das coníferas, normalmente menos densas, apresentam, em geral, velocidade mais elevadas do que as dicotiledôneas. Isto ocorre porque as coníferas, em sua maioria, têm estrutura mais homogênea.

\subsection{PRINCIPAIS PATOLOGIAS QUE AFETAM A MADEIRA}

O tempo por si só não produz depreciação das características da madeira (CRUZ, 2001). As patologias, portanto, surgem como resultado da ação de agentes físicos, químicos, mecânicos e biológicos, aos quais as peças de madeira estão sujeitas ao longo de sua vida útil.

A ação do intemperismo - weathering - é responsável pelas alterações de cor e textura dando à madeira a aparência envelhecida com tonalidade acinzentada de todas as peças de madeira expostas à luz solar e à chuva, encobrindo a coloração natural da madeira. Estas alterações aparecem pela decomposição química dos compostos da madeira por ação da radiação ultravioleta e da umidade, e constituemse geralmente em deterioração superficial, com conseqüências estéticas. 
O problema da biodeterioração surge quando a exposição à umidade é elevada, fato este que potencializa o risco de degradação da madeira pelos agentes biológicos.

Os agentes biológicos são organismos deterioradores que apresentam características morfológicas, fisiológicas e comportamentais especiais que os tornam capazes de utilizar a madeira como substrato, abrigo e alimento (ELEOTÉRIO e BERTI FILHO, 2000). No lenho estão presentes açúcares, gomas, resinas e amidos que constituem a base alimentar de organismos, como fungos, bactérias, cupins, brocas e moluscos (MADY, 2000), os chamados organismos xilófagos.

Desta forma, é possível afirmar que a durabilidade da madeira, está relacionada com a resistência desta de resistir ao ataque dos organismos xilófagos, no caso, resistência biológica. Cruz (2001) descreve os agentes biodeterioradores como a causa mais freqüente de deterioração das estruturas de madeira, sendo os responsáveis pela maioria das situações de ruptura parcial ou total das estruturas.

A probabilidade do ataque de xilófagos ocorrer pode ser prevista se houver condições favoráveis para que se desenvolvam esses organismos. Lelis et al. (2001) relaciona as condições de uso das peças de madeira com o risco de deterioração por agentes xilófagos, como fungos, brocas, cupins e insetos perfuradores marinhos (ex. moluscos). Sendo que as peças de madeira utilizadas acima do solo com exposição à umidade ocasional já se encontram na classe de risco de desenvolvimento de fungos, brocas e cupins.

A seguir são apresentados os principais tipos de organismos biodeterioradores da madeira encontrados em componentes de construção civil em uso, seus respectivos agentes desencadeadores e os principais danos causados.

\subsubsection{Fungos apodrecedores}

Umidade acima de $20 \%$ na madeira, ambiente com temperatura entre $25^{\circ} \mathrm{C}$ e $30^{\circ} \mathrm{C}$, presença de oxigênio, pouca luz solar e pH levemente ácido são as principais condições de risco para o desenvolvimento dos fungos na madeira (GONZAGA, 2006). Segundo Lelis et al. (2001), os fungos são organismos que necessitam de compostos orgânicos pré-elaborados como fonte de alimento - açúcares, proteínas e gorduras -, os quais são encontrados em grandes quantidades na madeira. 
Estes organismos utilizam as moléculas de celulose, hemiceluloses e lignina como fonte de alimento, alterando suas propriedades físicas e mecânicas e podendo comprometer o desempenho de peças estruturais (LELIS et al., 2001).

A ação dos fungos apodrecedores pode ser facilmente identificada pela perda de peso e de resistência da madeira, acompanhada por alterações típicas de coloração e de aspecto (CRUZ, 2001).

Os principais fungos que produzem podridão e afetam a resistência mecânica da madeira podem ser distinguidos em três tipos: fungos de podridão-mole, fungos de podridão-parda e fungos de podridão-branca.

Os fungos de podridão-mole deixam a peça de madeira atacada com a superfície amolecida, com trincas transversais. Se a peça de madeira apresentar aspecto de queimada, com rachaduras longitudinais, pode estar atacada por fungo de podridão-parda. Já se a peça apresentar bolsas brancas na superfície da madeira, ela pode estar sofrendo ataque de podridão-branca.

Monteiro et al (2007) descreve que as principais peças de madeira afetadas pelos fungos são as que estão em contato com o solo, áreas molháveis e apoiadas em paredes com infiltração de umidade. $O$ apoio do pilar de madeira na parede de taipa intensamente danificado por fungo apodrecedor xilófago, em uma edificação histórica da cidade de Bananal, apresentado na foto 8 , é um exemplo de peça de madeira vulnerável a esse tipo de ataque.

Em avaliações de campo, Brazolin et al. (1999) utilizou a análise visual e um estilete pontiagudo para caracterizar e quantificar o ataque do organismo xilófago em inspeção e diagnóstico das patologias de edifício histórico. Gonzaga (2006) também recomenda o uso de canivete pontiagudo para inspecionar peças de madeira, principalmente no caso de peças de difícil acesso, em locais úmidos e pouco arejados, pois muitas vezes sob uma superfície aparentemente sadia ou pintada, a madeira se encontra em estado inicial de apodrecimento. Esse teste também pode ser utilizado para detectar galerias de cupins. 


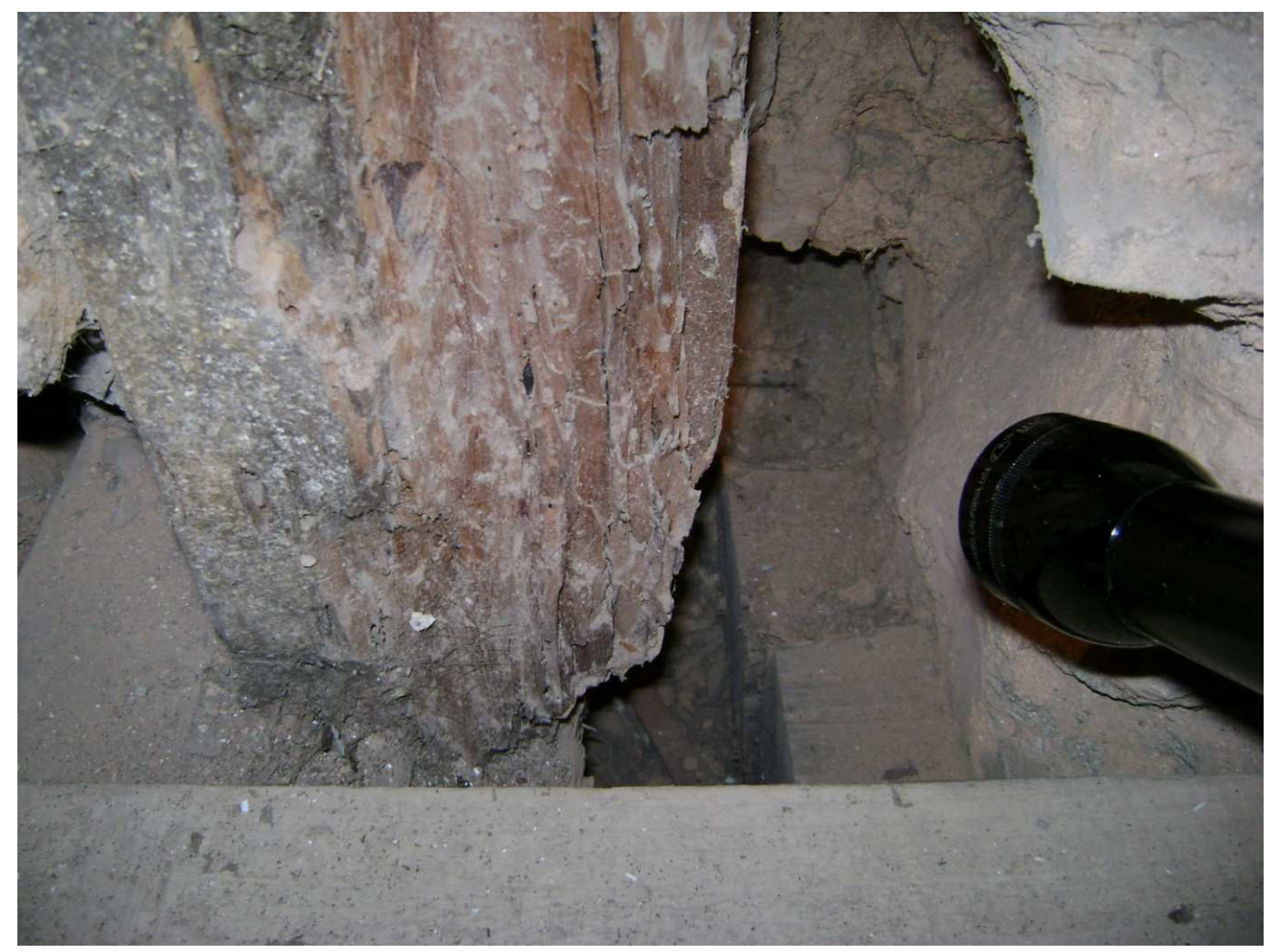

Foto 8 - Apoio de pilar com deterioração causada por fungo apodrecedor em parede de taipa do Sobrado Vallim na cidade de Bananal/SP.

\subsubsection{Cupins}

No meio urbano, os cupins são conhecidos, principalmente, pelo grave problema que causam ao atacar a madeira em uso e também outros materiais tais como papéis e tecidos (LELIS et al. 2001)

São insetos sociais que compõem colônias ou ninhos típicos com indivíduos operários, soldados e reprodutores.

Os principais grupos de cupins que atacam a madeira são os térmitas e os cupins-de-madeira-seca.

Segundo Lelis et al. (2001), quando os cupins nidificam dentro das próprias peças de madeira das quais de alimentam, são chamados de cupins-de-madeiraseca. $O$ ataque deste tipo de cupim é lento se comparado com o ataque de cupins subterrâneos e é percebido, principalmente, pelo acúmulo de resíduos, em forma de pequenos grânulos, excrementos, encontrados junto às peças atacadas. As galerias 
formadas por esses cupins possuem pequenos furos para aeração e despejo dos excrementos, formando montículos no piso onde caem (GONZAGA, 2006). Daí a dificuldade de quantificar $O$ ataque por cupins-de-madeira-seca nas peças de madeira. Enquanto os furos que aparecem na superfície da madeira podem ser muito pequenos, as galerias formadas por esses insetos podem reduzir a seção de peças estruturais e comprometer a sua resistência mecânica, deixando apenas a camada superficial da peça.

Caso a peça estiver em contato com umidade, o tipo de cupim que pode ser encontrado são os térmitas. Entre os térmitas, Lelis et al. (2001) apresenta os cupins-subterrâneos, assim denominados pelo fato de constituírem colônias freqüentemente abaixo da superfície do solo. Estes necessitam de uma fonte de umidade para sua sobrevivência e suas colônias são bastante populosas. A ligação entre a colônia e a fonte de alimento é feita por meio de túneis construídos pelos insetos.

O ninho do cupim-subterrâneo pode estar localizado tanto na área construída como nas imediações da construção. Em edificações infestadas por esses cupins é bastante comum encontrar seus túneis nos espaços existentes entre lajes, na rede hidráulica e em conduítes elétricos, assim como em peças em contato direto com a alvenaria (LELIS et al., 2001).

Um exemplo de peça de madeira do patrimônio histórico com ataque de cupim-de-madeira-seca é apresentado na foto 9 , a seguir. $O$ dano somente foi identificado pela presença de pequenos orifícios deixados pelos insetos. Internamente, a madeira possuía grandes galerias vazias. 


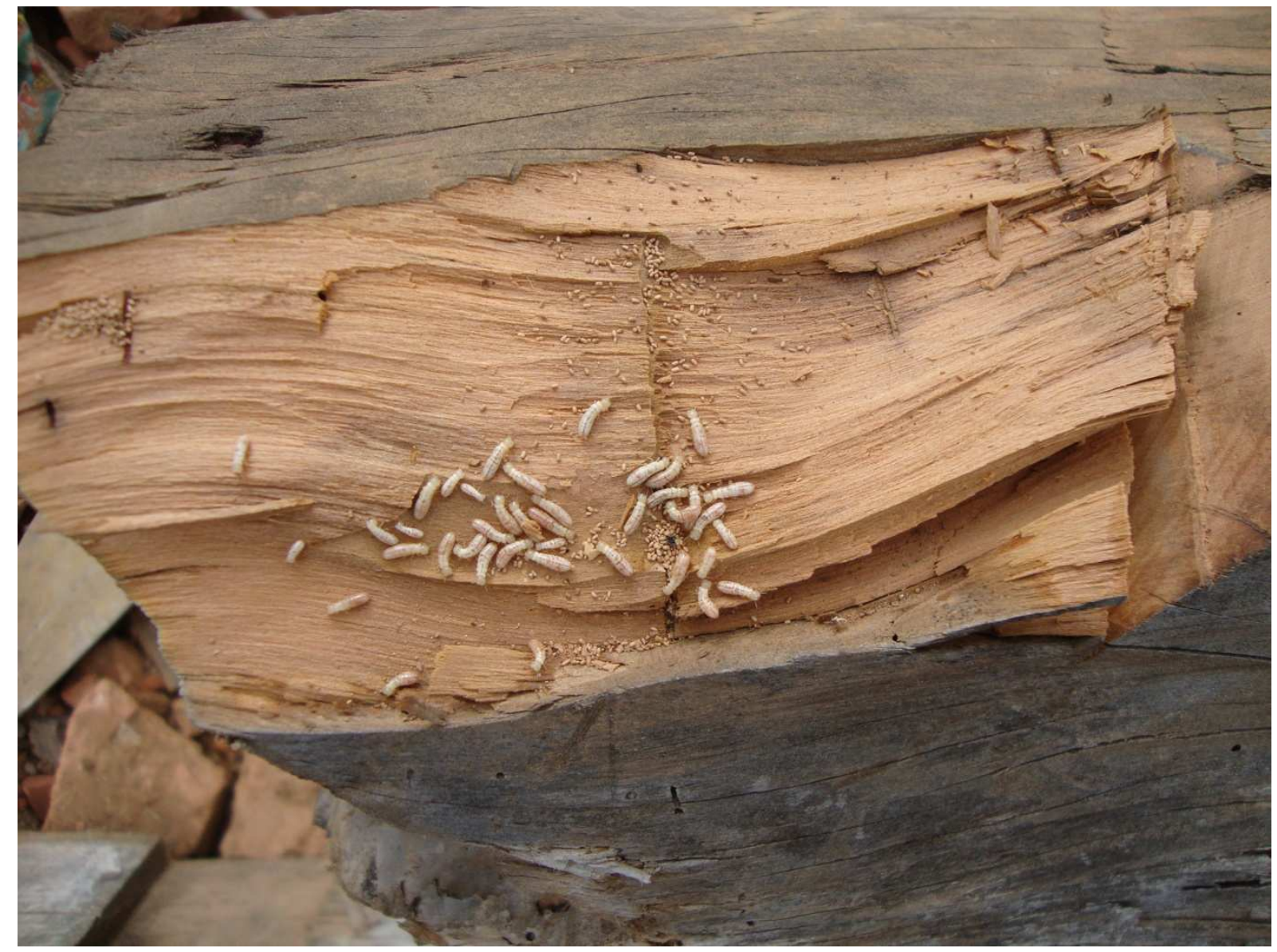

Foto 9 - Cupim de madeira seca em viga de peroba-rosa encontrada nos escombros de edificações do centro histórico de São Luiz de Paraitinga em junho de 2010.

A foto 10 apresenta uma viga de madeira com ataque de cupim-de-madeiraseca, demonstrando a intensidade do dano que esses insetos podem alcançar. 


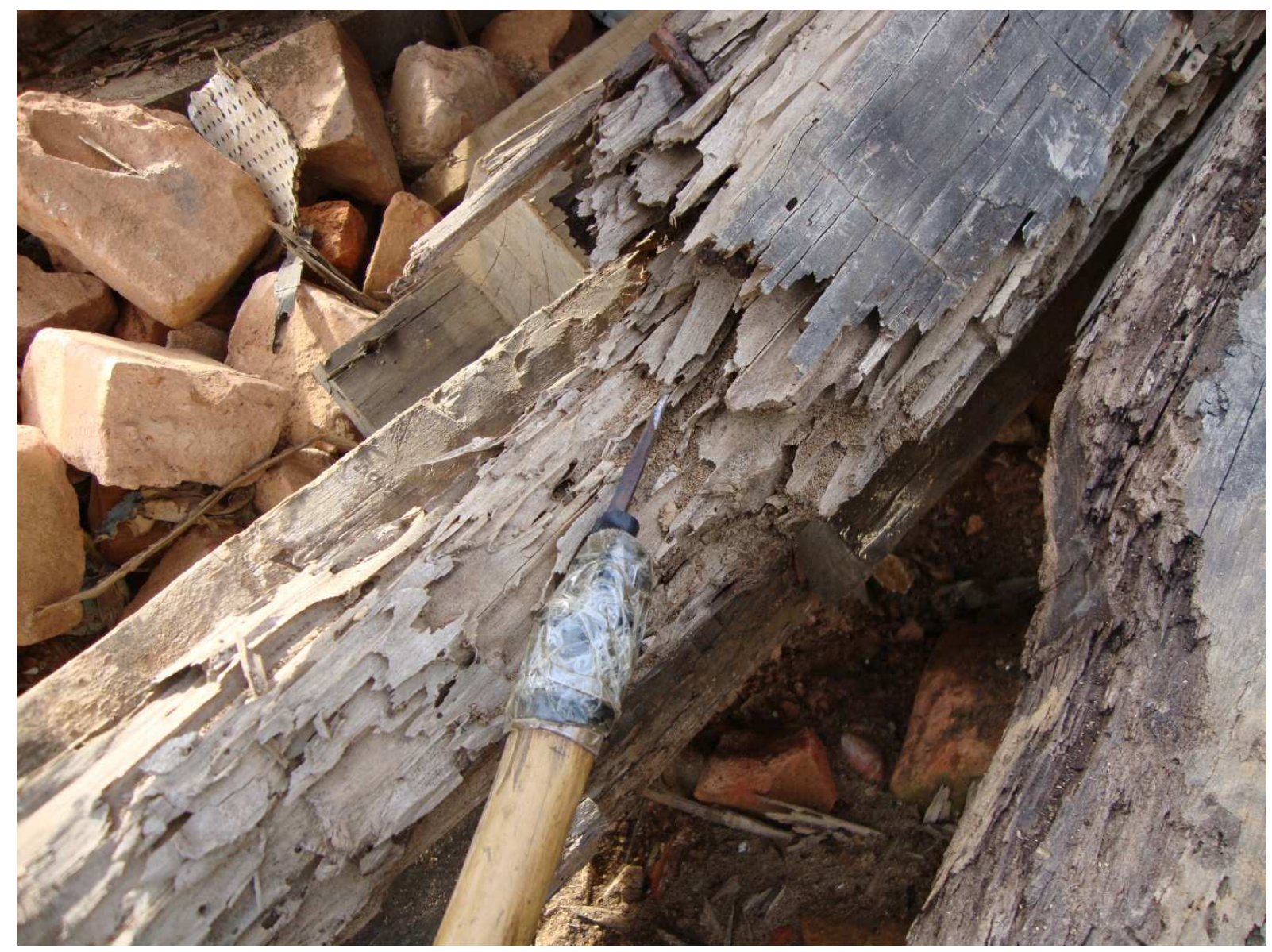

Foto 10 - Viga de madeira com ataque intenso de cupim-de-madeira-seca encontrada nos escombros de edificações do centro histórico de São Luiz de Paraitinga.

\subsubsection{Defeitos}

As madeiras têm suas características e propriedades mecânicas obtidas em ensaios destrutivos em corpos-de-prova sem defeitos, porém as peças de madeira usadas na construção civil, eventualmente podem apresentar defeitos decorrentes do crescimento da árvore, do desdobro e da secagem da madeira.

Os defeitos da madeira são aqueles provenientes do crescimento da árvore em função de condições ambientais adversas, como as decorrentes da ação do vento, como os desvios de fibra, fibras torcidas e nós soltos ou cariados. Os tipos mais comuns de alteração das fibras são apresentados na figura 6 .

Várias peças de peroba-rosa foram encontradas durante esta pesquisa com fibra revessa, inclusive os corpos-de-prova com esse tipo de fibra apresentaram menores resistências à flexão que os demais do conjunto. A fibra revessa é caracterizada pelo tipo espirado de fibra apresentado na figura 6. 

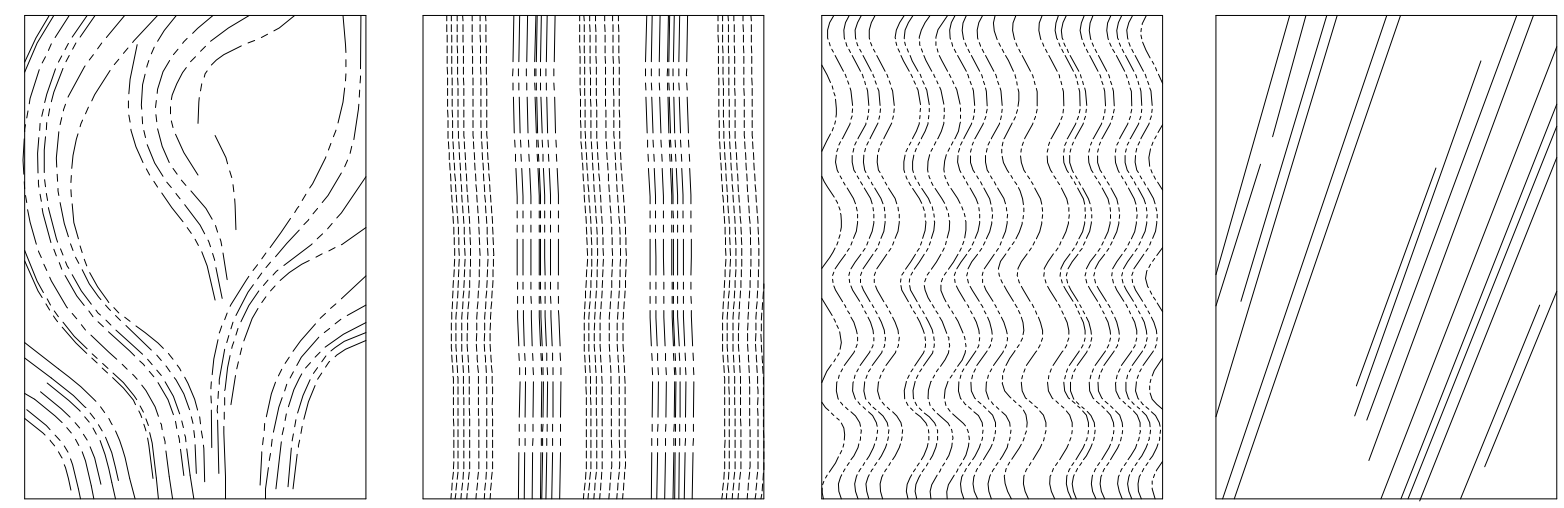

Figura 6 - Aspectos de grã irregular: espiralada; entrecruzada; ondulada; inclinada. (adaptado de MADY, 2000)

Os defeitos do processamento são os relacionados ao desdobro não controlado, enquanto os defeitos de secagem são os caracterizado pela retratibilidade e contração diferenciada da madeira durante a perda e ganho de umidade, compreendendo rachaduras, fendas, fendilhamentos e empenamentos. 


\section{O ULTRASSOM}

O princípio do ultrassom baseia-se no fenômeno da transmissão de um trem de ondas acústicas dentro de um material. É muito usado para determinar descontinuidades internas em concreto e metais (ANDREUCCI, 2009).

Chama-se ultrassom, pois utiliza a transmissão de ondas com freqüência acima do limite audível das ondas acústicas.

Um importante estudo do ultrassom na madeira é o de Bucur (2008) reeditado em 2008, onde apresenta a equação fundamental para a propagação das ondas de ultrassom em madeira, caracterizando os fatores que afetam a atenuação e a velocidade das ondas ultrassônicas.

Oliveira et al. (2003) fez experimentos com ultrassom em madeira de pinus (Pinus taeda e Pinus elliottii) e, apesar da variabilidade dos corpos de prova do lote estudado, com desvios da grã e elevada quantidade de nós, os resultados com transdutores de $22 \mathrm{kHz}$ demonstraram-se sensíveis às diferenças anatômicas das peças ensaiadas.

Também com experimentos de ultrassom em coníferas, pinus (Pinus radiata), Nogueira e Ballarin (2003), estudaram a sensibilidade à ortotropia elástica da madeira em corpos de prova para compressão, tendo concluído que o módulo de elasticidade dinâmico obtido com essa tecnologia é um bom estimador para o módulo de elasticidade estático. Em relação à ortotropia, o ultrassom com transdutores de $45 \mathrm{kHz}$, revelou sensibilidade na avaliação do módulo de elasticidade nas direções longitudinal e radial e não se mostrou sensível na avaliação do parâmetro na direção tangencial.

Bodig e Jayne (1982) haviam estimado que o módulo de elasticidade dinâmico da madeira é em torno de $5 \%$ a $15 \%$ superior ao módulo de elasticidade estático em experimentos correlacionando ultrassom e ensaios destrutivos.

Sobre a influência da umidade nos resultados com ondas de ultrassom, Terezo (2004) realizou testes em madeira seca, em equilíbrio e saturada de angelim e peroba e concluiu que a estrutura anatômica e os teores de umidade da madeira interferem na relação com o módulo de elasticidade estático da madeira. As melhores relações foram obtidas com os corpos de prova secos. 
Oliveira et al. (2006) estudou a influencia do tamanho dos corpos de prova nos resultados do ensaio de ultrassom com transdutores de $22 \mathrm{kHz}$, utilizando peças de pinus (Pinus caribaea), eucalipto citriodora (Eucalyptus citriodora), eucalipto grandis (Eucalyptus grandis) e jatobá (Hymenaea sp) com seção regular de $12 \mathrm{~cm} \times 5 \mathrm{~cm}$ e comprimentos variáveis de $300 \mathrm{~cm}$ a $10 \mathrm{~cm}$. Os resultados apontaram que ocorre variação da velocidade em função da distancia percorrida e do comprimento de onda utilizado.

Emerson et al.(1999) expõem entre as dificuldades associadas a inspeções de elementos estruturais de madeira com o ultrassom, a necessidade da perfeita acoplagem entre os transdutores e a superfície da madeira.

\subsection{EQUIPAMENTOS DE ULTRASSOM}

Os equipamentos de ultrassom utilizam de geradores de ondas ultrassônicos, feitos de material piezoelétrico, por exemplo, também chamados simplesmente de transdutores piezolétricos ${ }^{7}$.

De um modo geral, um transdutor é um dispositivo que converte um tipo de energia em outro. Os transdutores ultrassônicos convertem energia elétrica em energia mecânica e vice-versa.

O aparelho, disponível no Laboratório de Madeira e Produtos Derivados do IPT e que foi escolhido para a realização do método não destrutivo, é o $\mathrm{EPOCH} 4{ }^{\circledR}$, apresentado na foto 11 , com freqüência de $100 \mathrm{kHz}$ e transdutores piezoelétricos. Ele utiliza um visor de cristal líquido que identifica as descontinuidades sob a forma de um ecograma produzido por um sinal eletrônico. É composto de uma fonte com visor e painel de funções, na qual são acoplados dois transdutores. O primeiro (emissor) transforma impulsos elétricos em ondas de ultrassom, que são refletidas no interior do material analisado. O segundo (receptor) capta esses sinais, convertendo-os novamente em impulsos elétricos. Esses impulsos elétricos são apresentados na tela da fonte como um espectro de onda e com base na distância e no tempo de percurso das ondas de ultrassom, pode-se calcular a velocidade das mesmas. Num material que apresenta descontinuidades internas, como fissuras ou

\footnotetext{
${ }^{7} \mathrm{O}$ termo define o fenômeno piezoelétrico que consiste na variação das dimensões físicas de certos materiais sujeitos a campos elétricos.
} 
podridões, a propagação das ondas de ultrassom é mais lenta do que num material íntegro, pois ocorre atenuação das ondas.

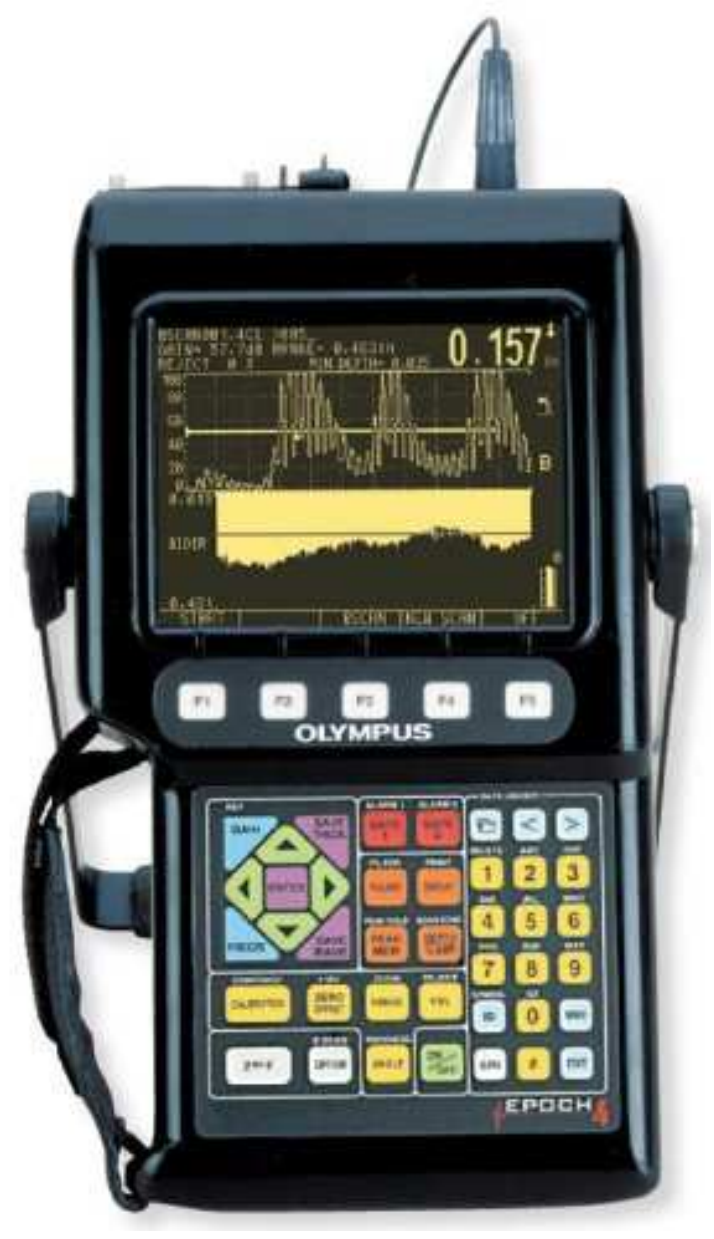

Foto 11 - Fonte com visor e painel do equipamento de emissão de ondas de ultrassom.

O equipamento foi utilizado com transdutores de ondas longitudinais e transdutores de ondas transversais. Sendo que, se a perturbação das ondas for paralela à direção de propagação, tem-se uma onda longitudinal. Já se a perturbação das ondas for perpendicular à direção de propagação, tem-se uma onda transversal. 


\section{ESTUDO EXPERIMENTAL}

A validação de métodos de ensaios é de fundamental importância para comprovar que um método não normalizado desenvolvido é capaz de obter resultados tecnicamente válidos e intercomparáveis (PIZZOLATO, 2001). Desta forma, o caminho mais seguro para a validação da metodologia de avaliação não destrutiva com uso de ultrassom para avaliação de estruturas de madeira do patrimônio histórico foi a definição de padrões de resistência mecânica a partir de ensaios destrutivos.

Considerando a grande variabilidade de espécies de madeira e tipos de carregamento das peças de madeira encontradas em imóveis tombados, o escopo dos ensaios experimentais para verificação da validade do método ultrassônico se concentrou em uma espécie de madeira mais recorrente nesse tipo de edificação, a peroba-rosa (Aspidosperma polyneuron).

A partir de amostras dessa espécie, foram realizados ensaios não destrutivos e destrutivos com o intuito de relacionar os resultados e identificar um padrão de resistência mecânica aceitável para a espécie de peroba-rosa, verificando também a reprodutibilidade e eficiência do método que utiliza ondas de ultrassom.

A seguir é apresentada a seqüência de ensaios realizados no âmbito desta pesquisa.

\subsection{SELEÇÃo DA ESPÉCIE}

A espécie de madeira Aspidosperma polyneuron, de nome popular perobarosa, é apresentada na bibliografia referente a patrimônio histórico e construção civil, como sendo uma madeira muito utilizada em peças estruturais de edificações do século XX, até a década de 1970. A partir desse período, foi restringida a exploração da espécie para evitar a sua extinção.

Em razão das diversas citações bibliográficas pesquisadas e da experiência verificada em visitas a edificações históricas, foi escolhida essa espécie de madeira para a consecução dos ensaios experimentais em laboratório. Outro fator importante que contribuiu para a sua escolha foi o fato dela ter resistência à biodeterioração moderada aos cupins e baixa a moderada aos fungos (IPT, 1989). 
Anterior ao século $\mathrm{XX}$, os registros indicavam que a madeira de peroba foi utilizada, embora sem citação do nome científico da variedade Aspidosperma polyneuron.

A amostragem dos ensaios experimentais foi definida a partir de uma etapa de intensa procura por peças de peroba-rosa para os ensaios de caracterização mecânica da madeira por meio de ensaios destrutivos e não-destrutivos.

Em se tratando, esta pesquisa, do tema da preservação do patrimônio histórico edificado, um dos requisitos principais para a definição da amostra era exatamente a existência da sua história, ou seja, que pudesse ser rastreado o histórico de carregamento das peças de madeira em uso. Desta forma, foi descartada a possibilidade de aquisição de vigas de madeira proveniente de empresas de demolição que não apresentavam rastreabilidade da origem das vigas de madeira.

A aquisição das amostras, portanto, se deu por intermédio de consultas e contatos realizados em visitas a imóveis em processo de restauro, em reforma ou arruinados com peças de descarte, em diversas cidades do Estado de São Paulo, pois se previa o aproveitamento de vigas com dimensões que permitissem a retirada de corpos-de-prova para os ensaios destrutivos.

$\mathrm{Na}$ procura de peças de madeira amostrais, foram percorridas as cidades de São Paulo, Pindamonhangaba e Cravinhos, e após a definição da amostra e dos ensaios, a cidade de São Luiz do Paraitinga.

Na cidade de São Paulo foi visitada a Igreja das Chagas do Seráphico Pai São Francisco, construída entre os anos de 1672 e 1783 em taipa com cobertura de estrutura de madeira, tombada pelo CONDEPHAAT em 1982; e o prédio em reforma do Centro de Tecnologia Naval do IPT, construído na década de 1960 em paredes de tijolos e cobertura de madeira

Na cidade de Pindamonhangaba foi visitado o Palacete 10 de Julho, localizado no centro histórico da cidade. O Palacete foi construído na segunda metade do século XIX e foi tombado pelo CONDEPHAAT em 1969.

Em Cravinhos, foi visitada a Igreja de São Benedito, construída em 1888, tombada em 1985 e arruinada desde o dia 24 de fevereiro de 2009. 
Uma vez identificadas as amostras, verificou-se que somente em duas edificações visitadas foi encontrada a espécie almejada.

A partir da definição do requisito e da disponibilidade, foram então reunidas duas amostras consideradas representativas de estruturas de madeira de perobarosa de patrimônio histórico. Uma amostra retirada de peças dos escombros da Igreja de São Benedito de Cravinhos e outra amostra retirada de vigas das tesouras de cobertura descartadas na reforma de prédio do Centro de Tecnologia Naval do IPT.

Posteriormente foi definida outra amostra adquirida em serraria, para efeito comparativo com as peças "usadas" das duas amostras retiradas dos edifícios históricos, com o objetivo de identificar padrões de avaliação mecânica de peças estruturais de peroba-rosa.

\subsection{IDENTIFICAÇÃO BOTÂNICA}

A opção por amostras da mesma espécie de madeira, porém de diferentes proveniências, exemplifica não só a condição de uso no patrimônio histórico a que este trabalho remete, mas também à diversidade das propriedades físicas e mecânicas da madeira presente em indivíduos numa mesma espécie botânica.

A peroba-rosa é facilmente identificada pela sua coloração rósea, porém isto não é uma regra geral, conforme demonstra a foto 12. Lemos (1989) e Saia (1978) descrevem a peroba-rosa como sendo uma madeira predominantemente de coloração rósea, porém podendo ser encontrada na coloração amarelada. A cor e a presença ou não de fibra revessa são condicionadas pelas características geográficas e climáticas do local de crescimento da árvore.

As características, chamadas sensoriais, da madeira de peroba-rosa são seu cerne róseo quando recém cortada passando a amarelo-rosado com o tempo; uniforme ou com veios mais escuros; sem brilho; de cheiro imperceptível e gosto ligeiramente amargo; densidade média; moderadamente dura ao corte; com grã direta ou revessa; de textura fina (IPT, 1989).

A constatação dessas características permite uma suposição aproximada da espécie, devendo esta ser confirmada por especialistas. 


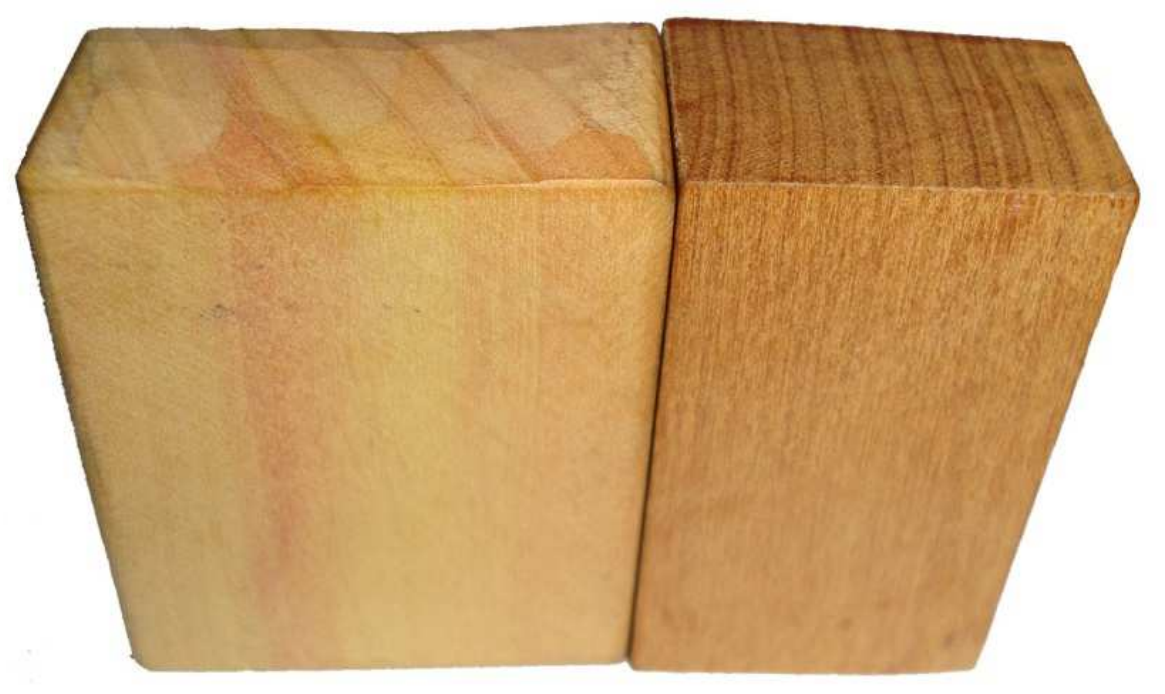

Foto 12 - Peças com altura de $50 \mathrm{~mm}$ e espessura de $30 \mathrm{~mm}$ da espécie peroba-rosa (Aspidosperma polyneuron) apresentando diferentes colorações.

A identificação botânica foi realizada com base na análise da anatomia do lenho de cada segmento retirado de peças de madeira.

Uma vez que as madeiras apresentam uma organização interna bastante característica e variável entre diversos grupos, podem ser formados padrões de imagens para cada espécie (IPT, 2010). Existem dois tipos de processos de identificação: macroscópica e microscópica.

O processo macroscópico é um método rápido que permite a identificação da maioria das madeiras comerciais. Utiliza-se uma faca de polimento e uma lupa conta-fios (10 aumentos) para observação e posterior comparação com as amostras identificadas e depositadas no acervo do Laboratório de Madeira e Produtos Florestais do IPT, conforme ilustrado na foto 13. 


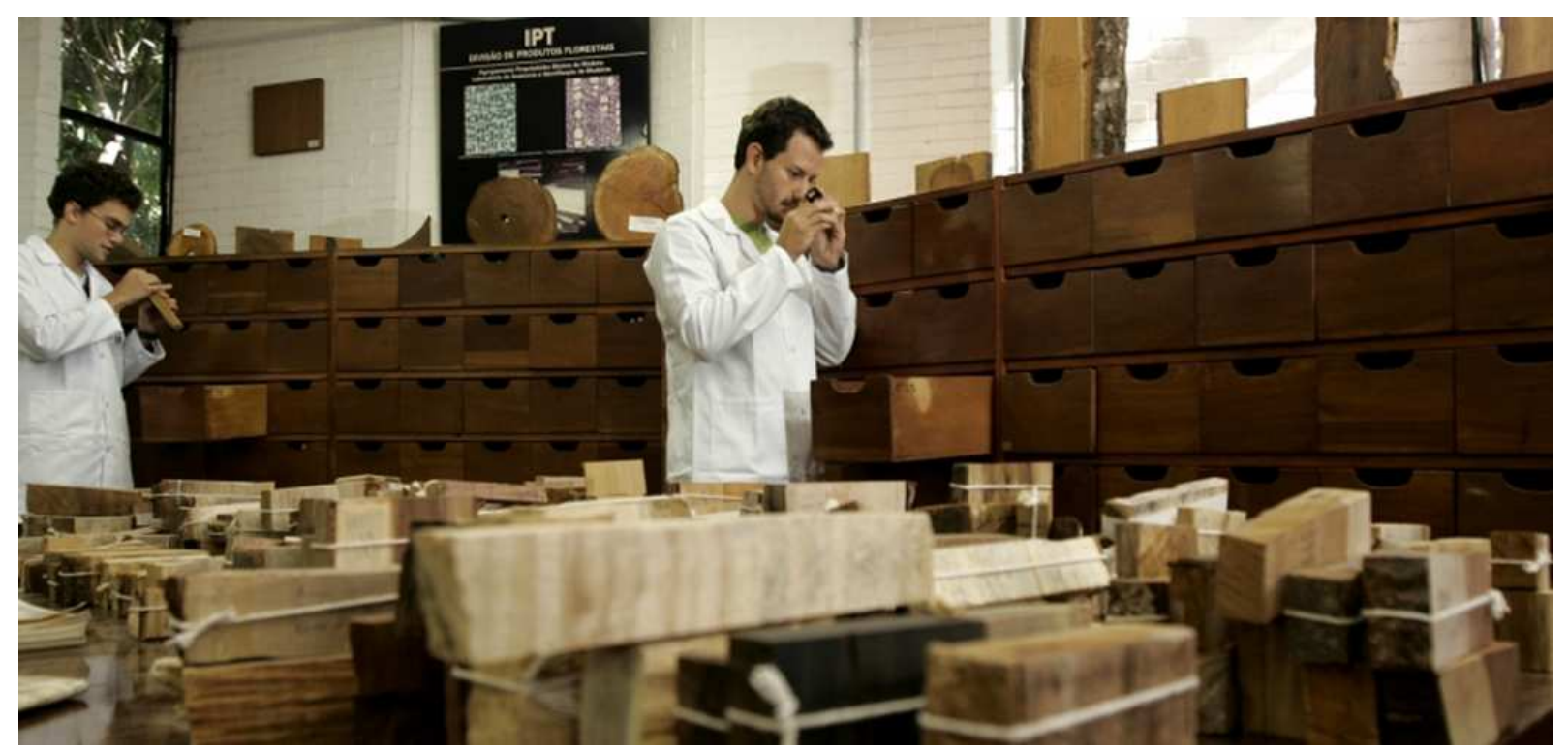

Foto 13 - Identificação da madeira pelo método macroscópico de analise do lenho. (Fonte: IPT, 2010)

Segundo o método de ensaio do IPT, o processo microscópico exige a preparação cuidadosa de uma lâmina histológica e a observação desta em microscópio óptico. A estrutura da madeira (foto 14) observada em detalhe é comparada com a coleção de mais de 13 mil lâminas histológicas existentes no laboratório, ou bancos de dados eletrônicos elaborados no IPT ou em Institutos de outros paises.

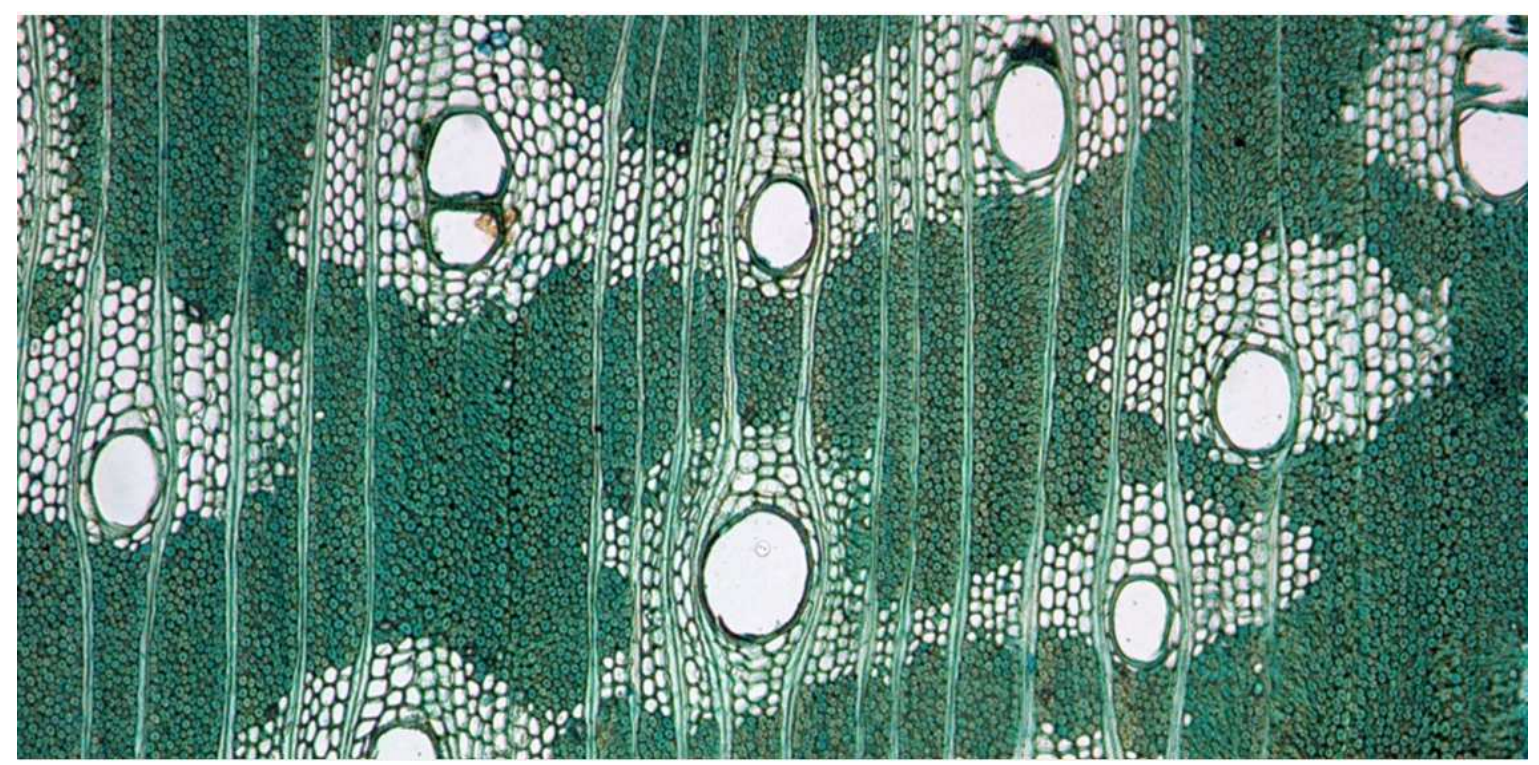

Foto 14 - Imagem obtida em microscópio para identificação da madeira (Fonte: IPT, 2010). 
Todas as peças de madeira selecionadas para os ensaios experimentais desta pesquisa tiveram a sua espécie confirmada no Laboratório de Propriedades Físicas e Mecânicas da Madeira do IPT, como sendo da espécie peroba-rosa (Aspidosperma polyneuron).

A identificação das espécies ajuda na classificação mecânica da madeira de acordo com o padrão específico da espécie caracterizada em laboratório, pois, em espécies nativas de seções de grandes dimensões, a variabilidade mecânica e física da madeira é muito pequena. Já quando se trata de espécies de reflorestamento de rápido crescimento, a variabilidade é muito maior e se torna impreciso prever as características mecânicas de uma peça de madeira por meio de sua identificação botânica.

O processo de identificação botânica requer a retirada de uma pequena amostra que permita ver as duas faces da madeira, tangencial e radial em relação aos anéis de crescimento.

\subsection{AMOSTRAGEM}

Após a seleção criteriosa, o material deste estudo consistiu de três amostras de procedências distintas pelo tempo de uso, embora Larsten (2000) em ensaios conduzidos em madeira afirme que não há perda de resistência mecânica em condições favoráveis de uso, ou seja, longe de fontes de umidade, calor, intemperismo e organismos xilófagos.

As três amostras selecionadas para este estudo caracterizam o uso em edificações com aproximadamente 122 anos, 50 anos e madeira sem uso, embora não seja preciso afirmar que as peças amostradas sejam originais da construção.

Para efeito de controle das amostras, estas foram codificadas como:

- Amostra A: duas vigas de peroba-rosa de seção $60 \mathrm{~mm}$ x $160 \mathrm{~mm}$ da Igreja São Benedito do município de Cravinhos, construída há 122 anos.

- Amostra B: duas vigas de peroba-rosa retiradas de tesoura de cobertura descartada na reforma do prédio do Centro de Tecnologia Naval do IPT, construído há aproximadamente 50 anos; e 
- Amostra C: 20 vigas de peroba-rosa sem uso, provenientes de uma serraria em São Paulo.

A seguir são descritas separadamente estas amostras que foram objeto do estudo experimental do trabalho.

\subsubsection{Amostra A}

A amostra A representa a Igreja de São Benedito na cidade de Cravinhos, localizada a 15 km de Ribeirão Preto e a 297 km de São Paulo, a qual foi visitada após sofrer colapso de suas estruturas e ruir no dia 24 de fevereiro de 2009. Esta igreja foi construída em 1888 e foi tombada em 1985, restando atualmente apenas a fachada.

Entre os escombros de madeira, no dia 3 de março de 2009, foram retiradas duas vigas com dimensões aproximadas de $60 \mathrm{~mm} \times 160 \mathrm{~mm}$ de seção retangular e comprimento de aproximadamente $2000 \mathrm{~mm}$.

Ambas as vigas recolhidas em campo foram encaminhadas para a identificação do lenho no Laboratório de Madeira e Produtos Derivados do IPT, onde foi confirmada a espécie Aspidosperma polyneuron.

As fotos 15 e 16 mostram as ruínas da igreja no dia da retirada das vigas da amostra. 

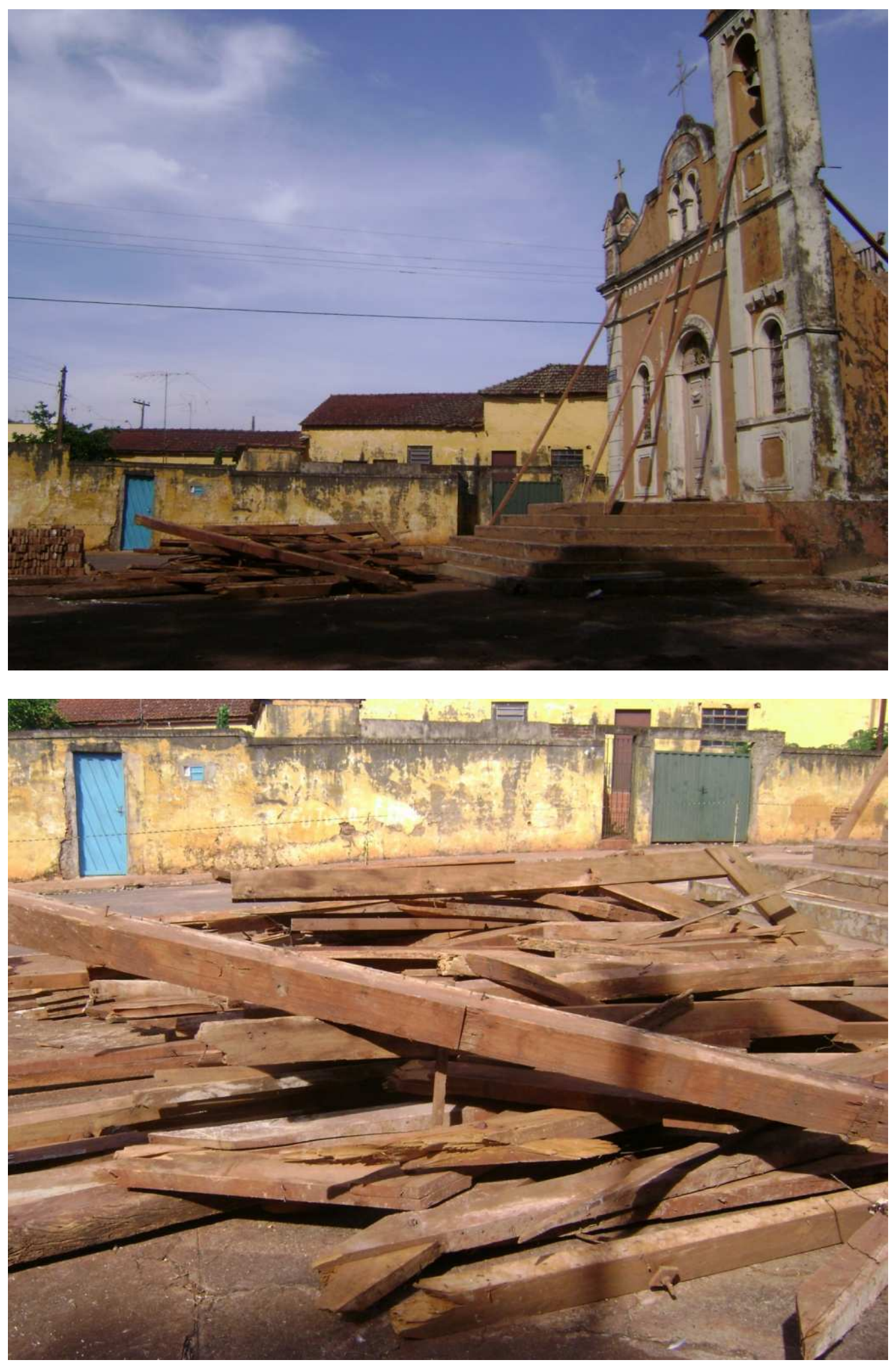

Fotos 15 e 16 - Escombros da Igreja de São Benedito em Cravinhos durante visita em três de março de 2009. 


\subsubsection{Amostra B}

A amostra B representa uma edificação com tempo aproximado de uso de 50 anos, pois foi retirada das tesouras do prédio do Centro de Tecnologia Naval do IPT, construído na década de 1960. Trata-se de um dos primeiros prédios construídos no campus do IPT.

As tesouras estavam constituídas de peças de madeira com seção retangular de $60 \mathrm{~mm} \times 160 \mathrm{~mm}$ e venciam um vão de $8.000 \mathrm{~mm}$.

A tesoura cedida para a pesquisa é apresentada na foto 17 .

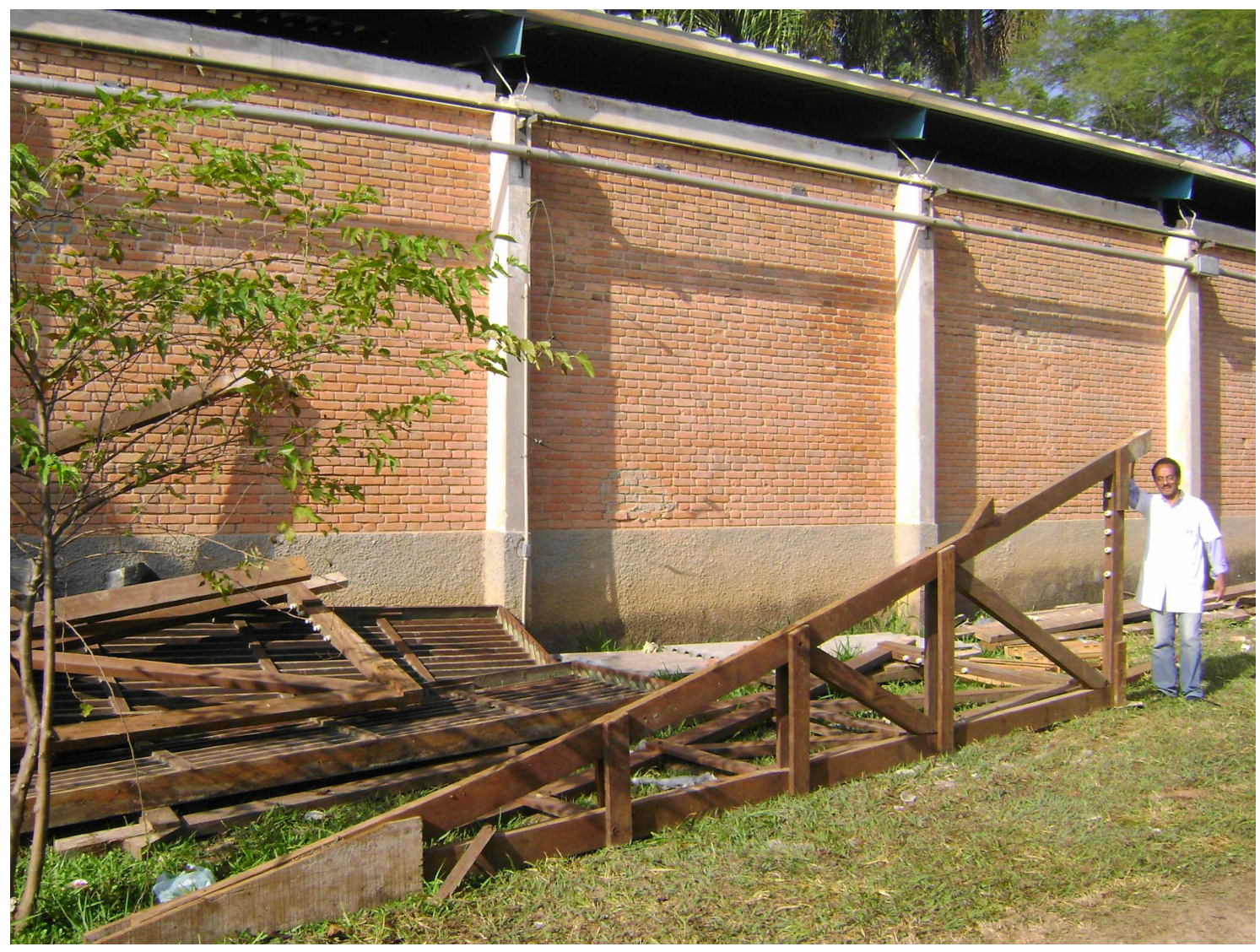

Foto 17 - Tesoura retirada da reforma de prédio do CT-NAVAL do IPT, em São Paulo.

\subsubsection{Amostra C}

A amostra é representativa de peças sem uso, e foi composta de 20 vigas de madeira adquirida na Serraria Amarante, localizada em São Paulo, com verba do CNPq. 
As vigas possuíam seção de $60 \mathrm{~mm} \times 120 \mathrm{~mm}$ e $2.000 \mathrm{~mm}$ de comprimento.

Todas elas foram enumeradas e acondicionadas em ambiente coberto e ventilado até atingir o teor de umidade em equilíbrio, em torno de $12 \%$, previamente aos ensaios.

Os corpos-de-prova retirados das vigas da amostra são apresentados na foto 18 .

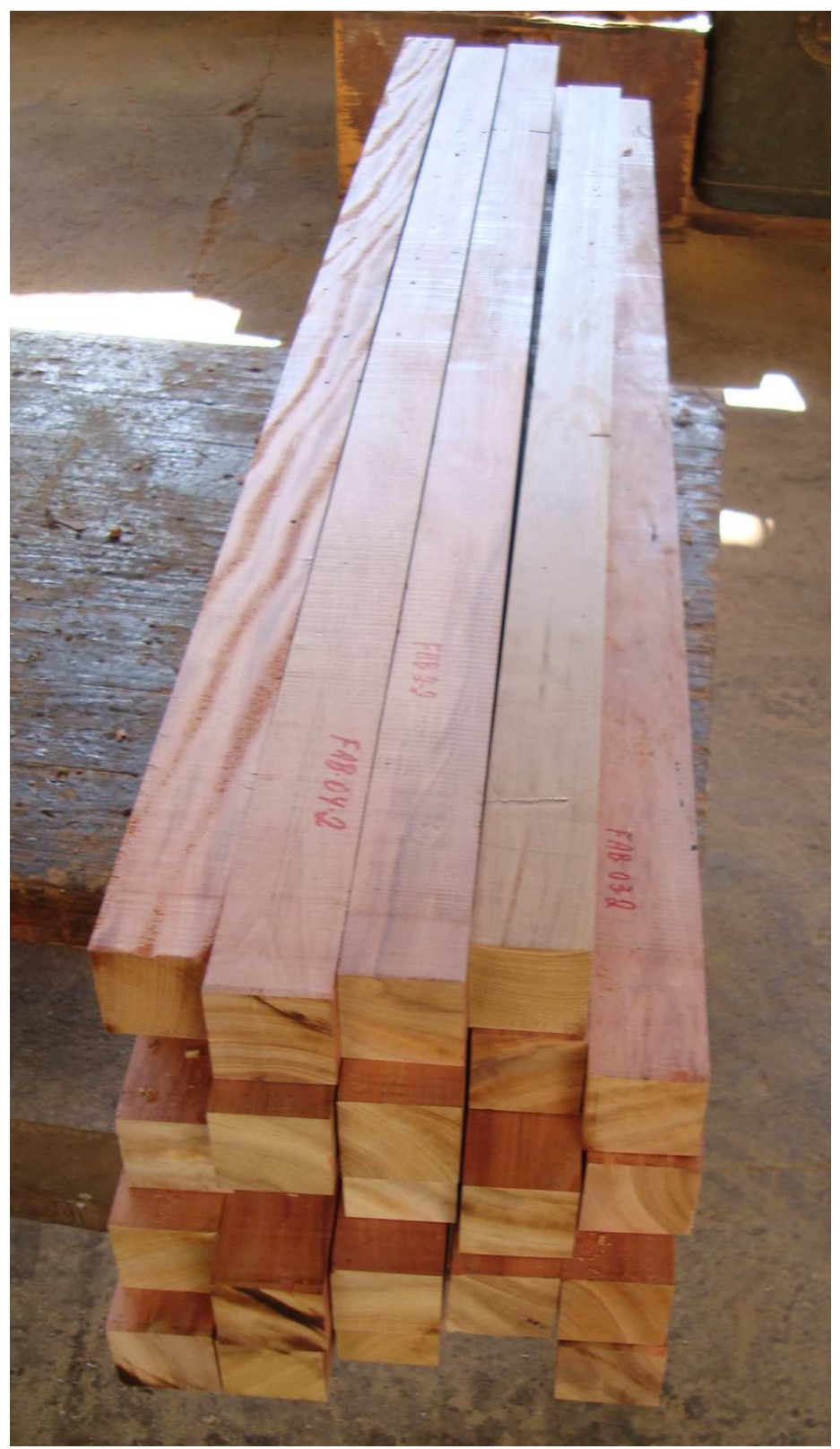

Foto 18 - Corpos-de-prova nas dimensões de $50 \mathrm{~mm}$ x $50 \mathrm{~mm} \times 1015 \mathrm{~mm}$ para ensaios de flexão retirados das vigas adquiridas em serraria, sem uso. 


\subsection{ACERVO DE ESPÉCIES}

Complementarmente à definição das amostras $A, B$ e $C$, verificou-se que o trabalho de coleta das diversas peças de madeira e a identificação das espécies usadas nas diferentes edificações visitadas poderia formar um pequeno, mas representativo, acervo de espécies de madeira utilizadas em imóveis históricos do século XIX e XX nessas cidades.

O local escolhido para compilar esse acervo foi a cidade de São Luiz do Paraitinga, considerada representante do maior conjunto histórico do século XIX no Vale do Paraíba, e a qual foi palco de um dos maiores danos provocados ao patrimônio histórico noticiados até o presente momento.

O centro histórico de São Luiz do Paraitinga, após a enchente do Rio Paraitinga entre os dias 31 de dezembro de 2009 e dois de janeiro de 2010, sofreu com o arruinamento e desabamento de diversas edificações tombadas pelo CONDEPHAAT. Nessa ocasião foram acompanhados os trabalhos de verificação das patologias e acompanhamento dos reforços provisórios das estruturas das casas com riscos iminentes de desabamento, junto à equipe de profissionais do IPT. A grande quantidade de escombros de madeira presente nos locais afetados permitiu, portanto, a retirada de diversos segmentos de vigas para identificação botânica.

A cidade de São Luiz do Paraitinga possui 426 imóveis tombados pelo CONDEPHAAT, sendo que 65 destes imóveis foram parcialmente afetados e 18 foram arruinados, em função da referida enchente do Rio Paraitinga. Entre os imóveis arruinados mais importantes da cidade, estão a Igreja Matriz de São Luiz de Tolosa, datada do século XIX e a Capela das Mercês, construída no fim do século XVII.

Os imóveis arruinados eram predominantemente casarões de taipa, pau-apique, madeira e cantaria, construídos em meados do século XIX.

No dia 20 de janeiro de 2010, foram coletados 26 segmentos dos escombros presentes na Rua Barão do Paraitinga e na Praça Oswaldo Cruz, no centro histórico da cidade, conforme locais indicados nas fotos 19 a 23. As peças para a retirada de segmentos de madeira deveriam ser originais da época de construção das edificações, portanto, necessariamente, foram selecionadas aquelas lavradas à 
machadinha e com dimensões robustas de aproximadamente $200 \mathrm{~mm} \times 200 \mathrm{~mm}$ e comprimentos até 8 metros.

O objetivo era identificar as espécies de madeira mais utilizadas e verificar a incidência da peroba-rosa na construção de edifícios do século XIX.

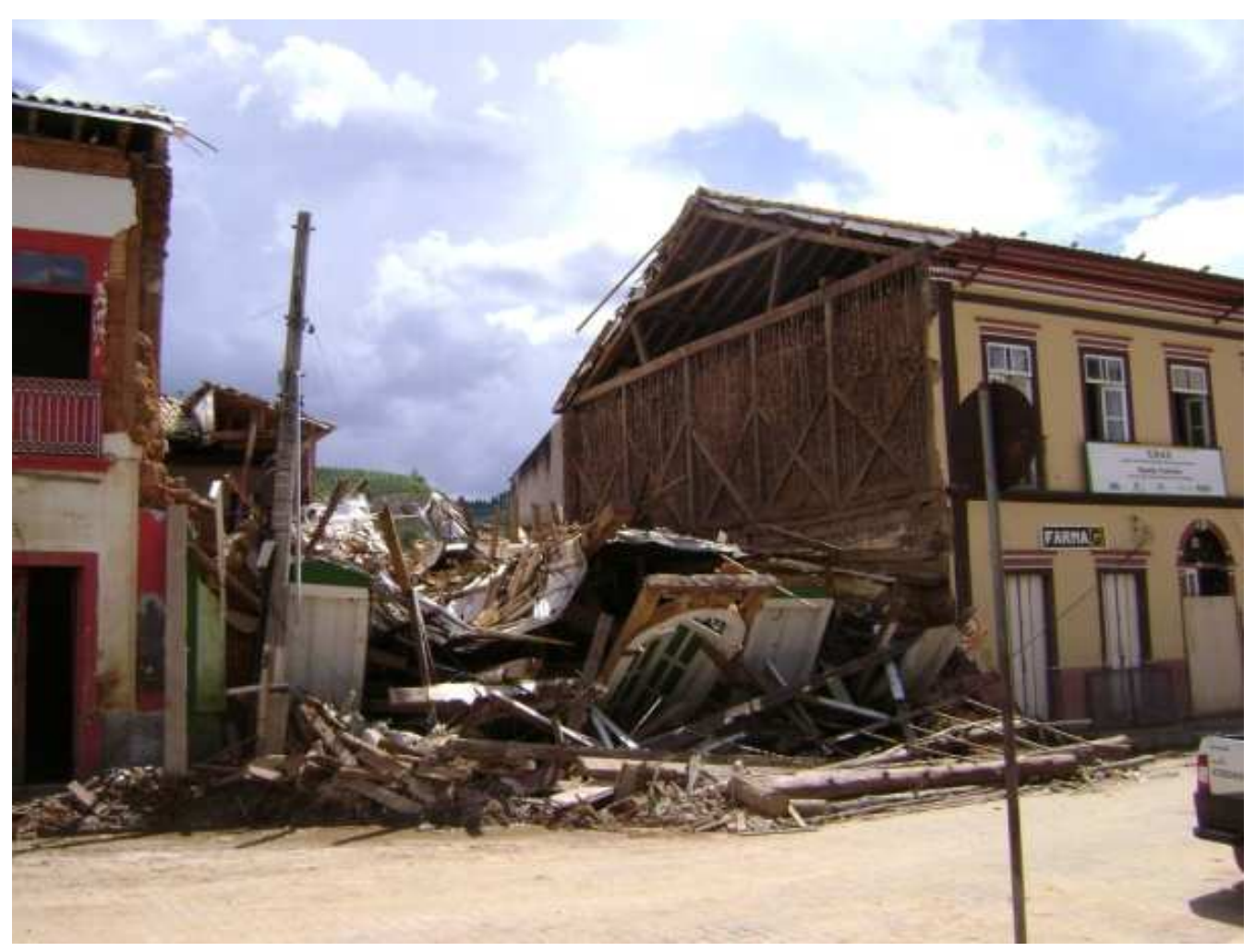

Foto 19 - Escombros do casarão em frente à Praça Oswaldo Cruz na cidade de São Luiz do Paraitinga em janeiro de 2010, após enchente do Rio Paraitinga. 


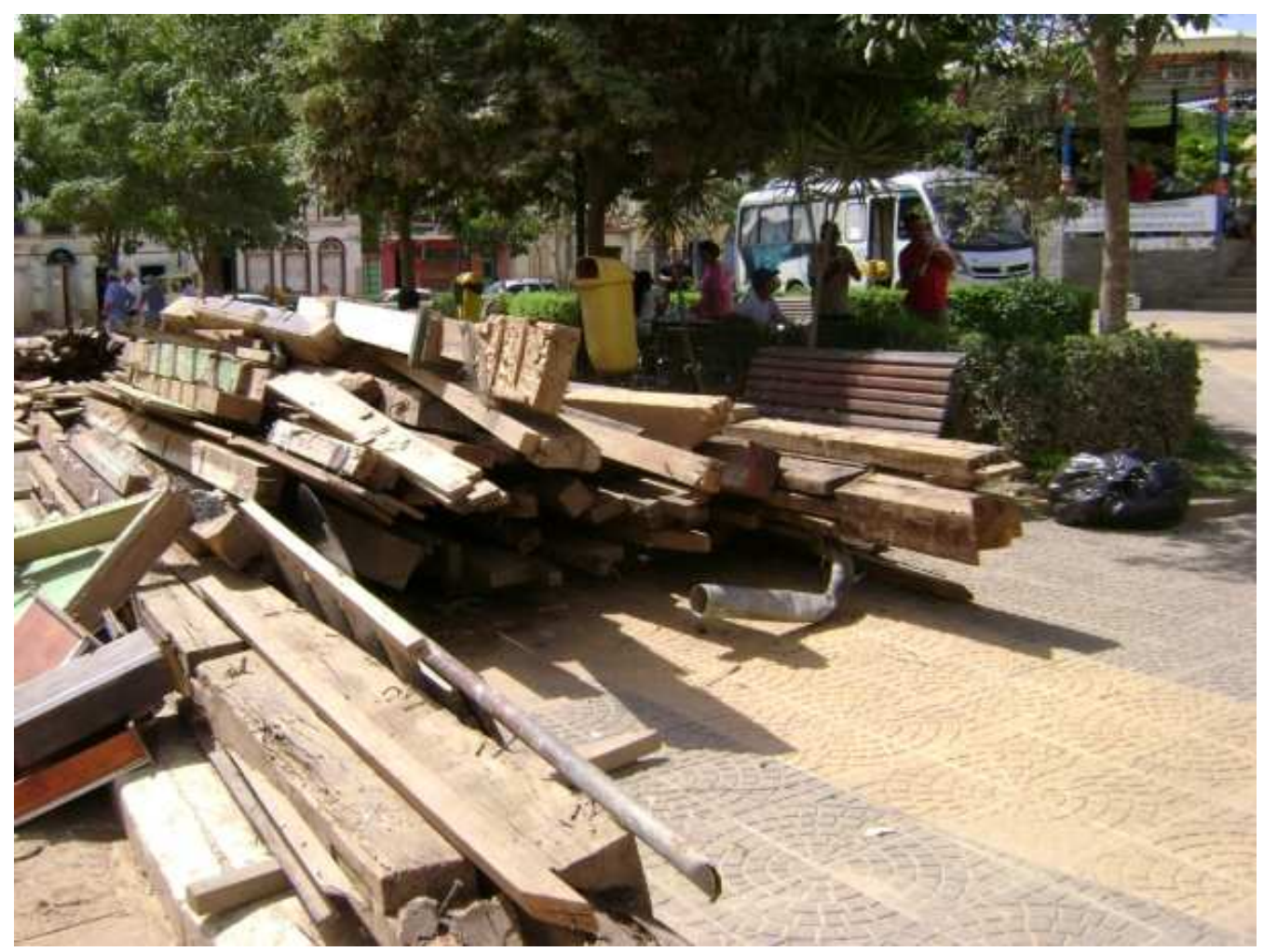

Foto 20 - Escombros de madeira reunidos na Praça Oswaldo Cruz, centro histórico de São Luiz do Paraitinga.

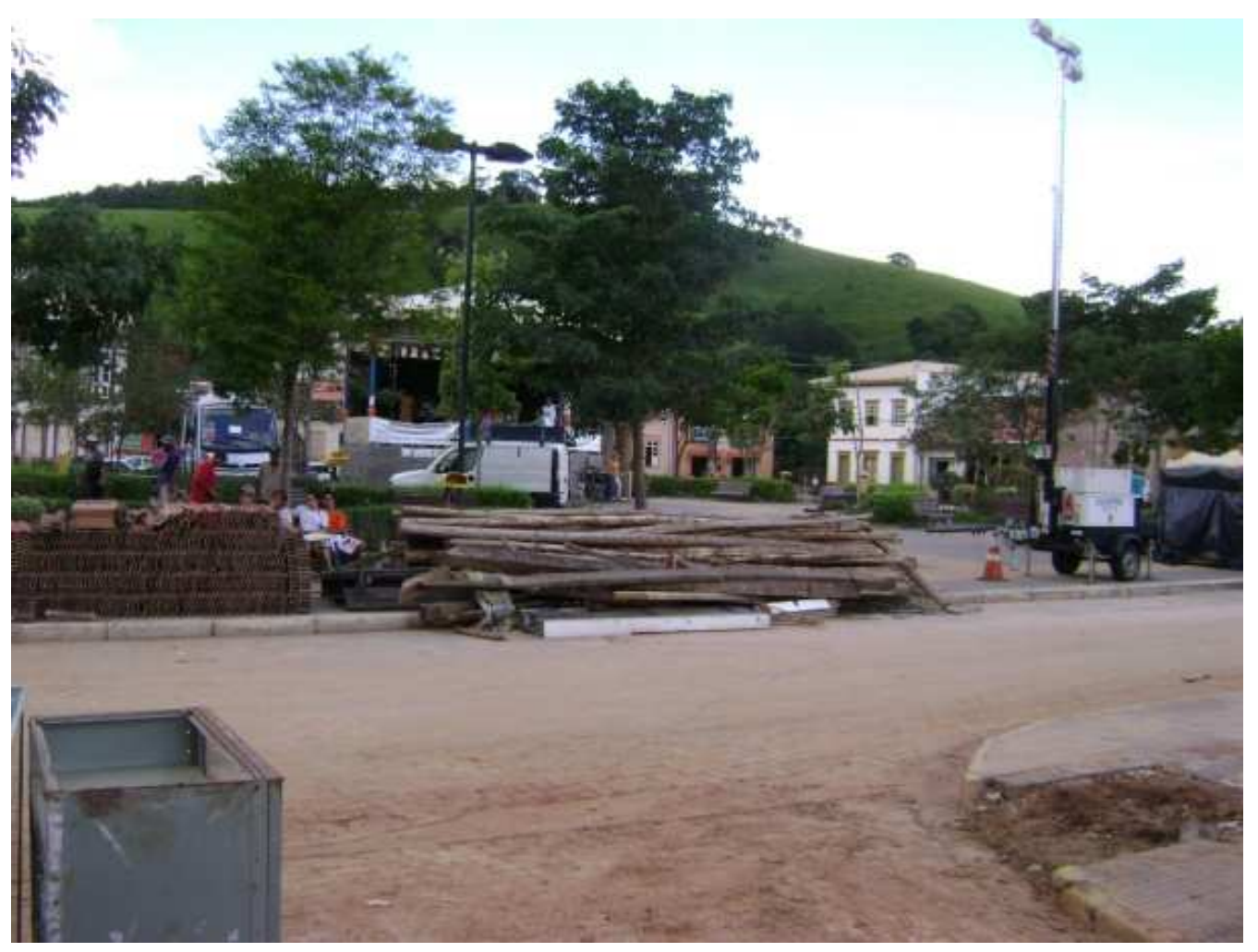

Foto 21 - Vigas de ruínas decorrentes da enchente do Rio Paraitinga. 


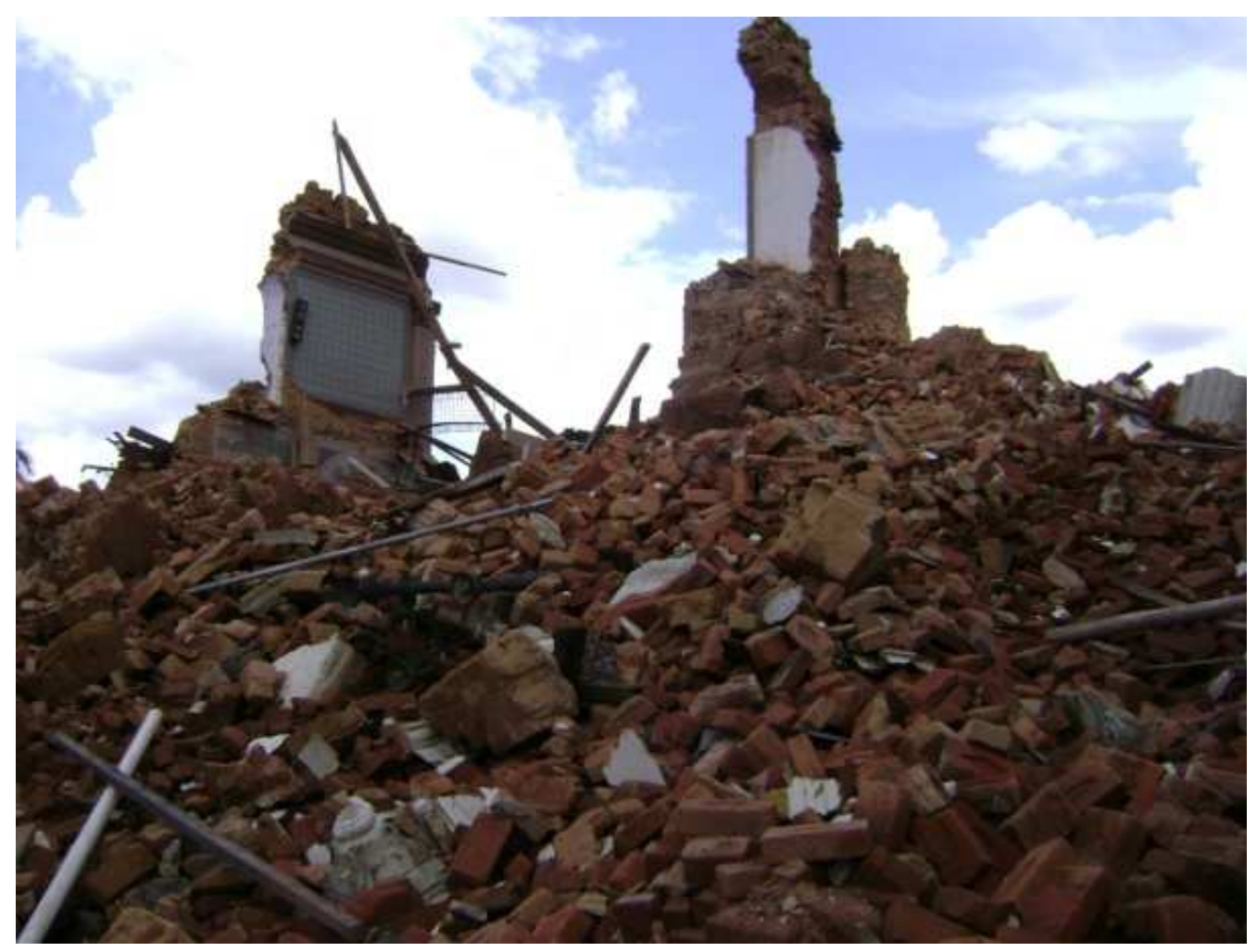

Foto 22 - Ruínas da Igreja Matriz de São Luiz de Tolosa.

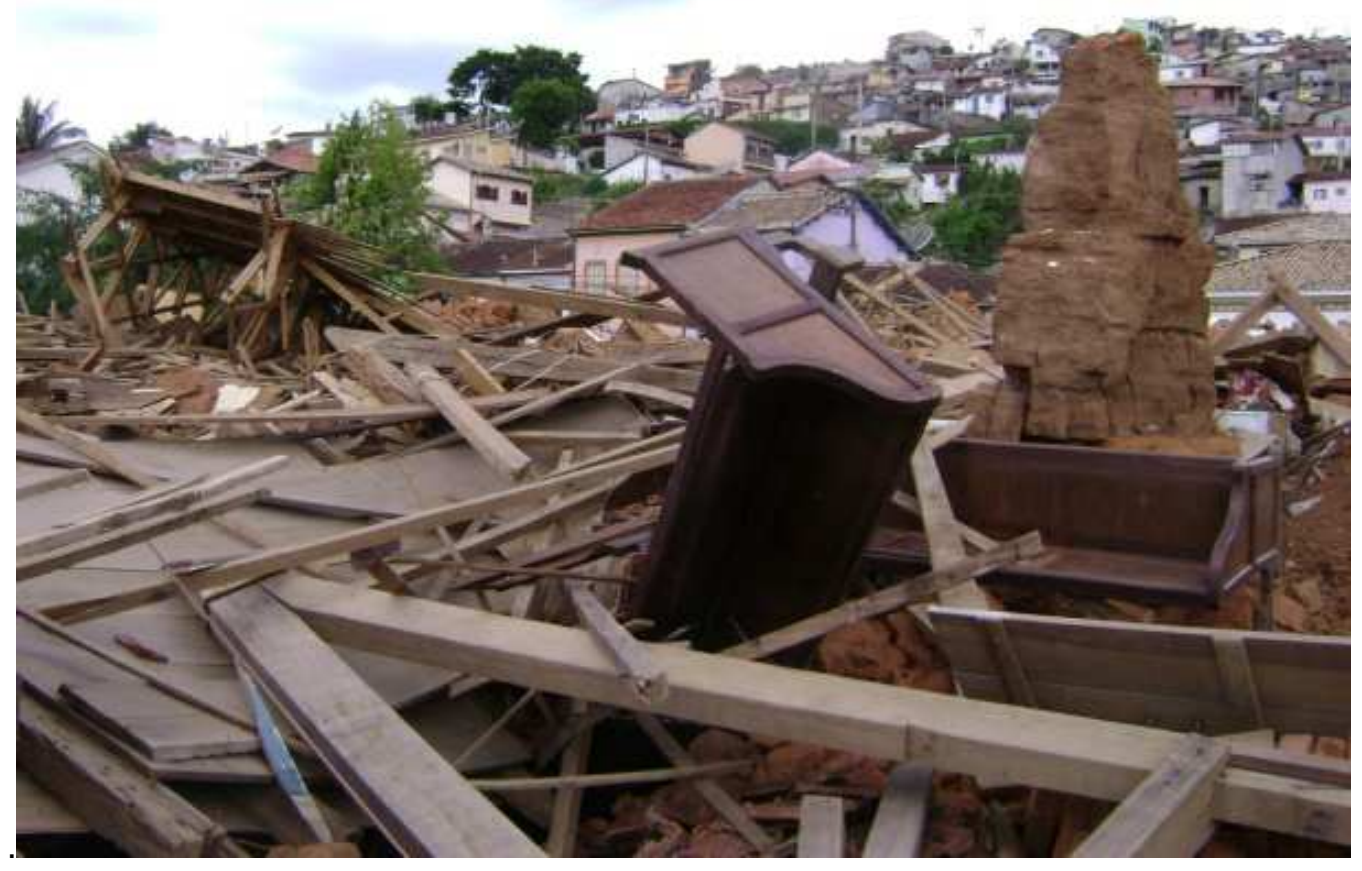

Foto 23 - Peças de madeira das ruínas da Igreja Matriz de São Luiz de Tolosa. 
Os 26 segmentos de madeira, conforme apresentado na foto 24 , foram enumerados conforme a ordem de retirada, e encaminhados ao Laboratório de Madeira e Produtos Derivados do IPT, mais especificamente, ao setor que desenvolve estudos sobre anatomia e identificação de madeiras, para a identificação botânica das espécies.

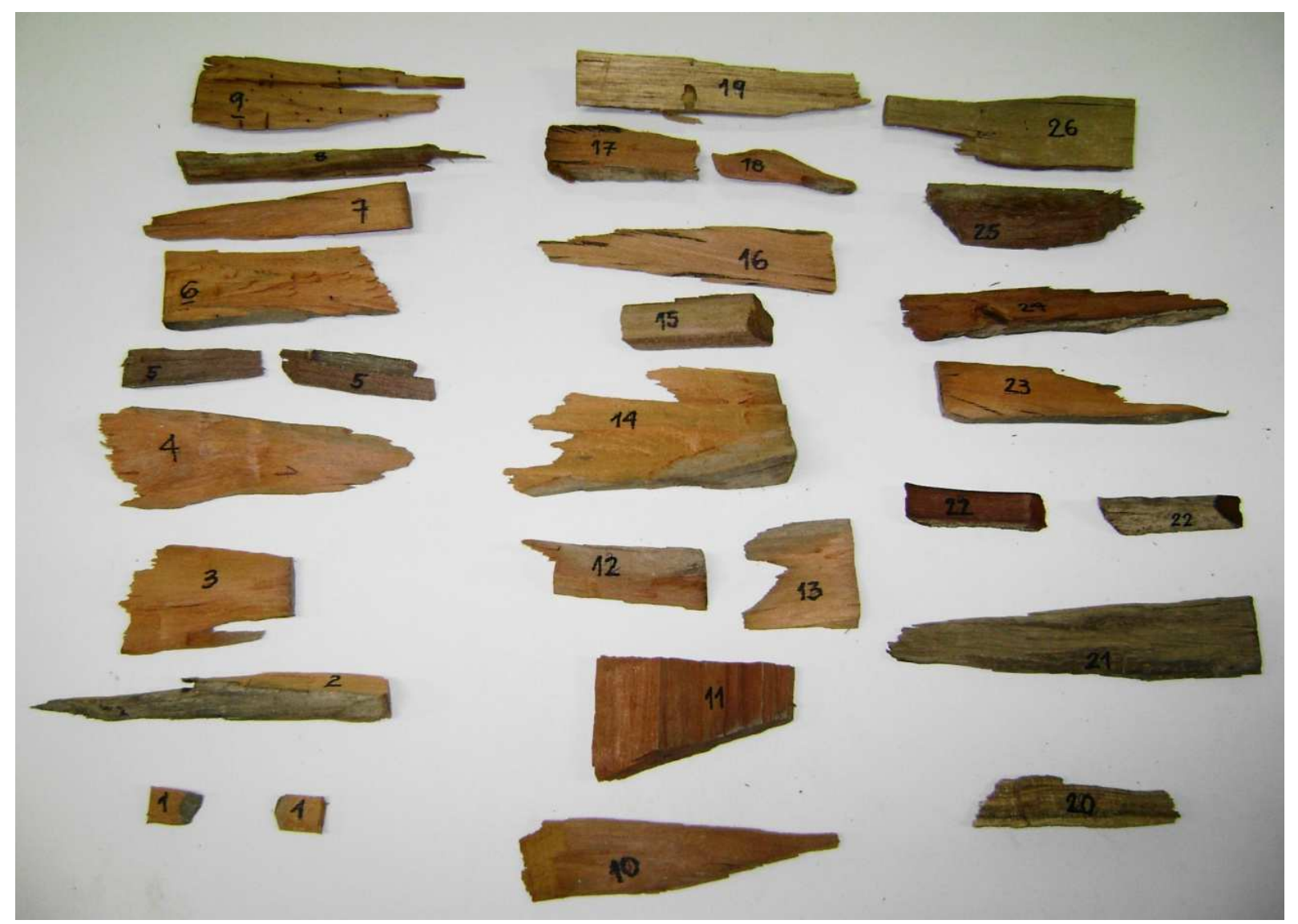

Foto 24 - Segmentos de madeira retirados das ruínas das edificações do centro histórico de São Luiz do Paraitinga, em visita do dia 20 de janeiro de 2010.

Os resultados da identificação desses segmentos de madeira são apresentados na tabela 2 , a seguir. 
Tabela 2 - Identificação das espécies de 26 segmentos retirados de escombros de edificações construídas no século XIX no centro histórico de São Luiz do Paraitinga.

\begin{tabular}{|c|c|c|c|}
\hline Nome popular & Nome científico e família & $\begin{array}{l}\text { Número do } \\
\text { segmento }\end{array}$ & $\begin{array}{c}\text { Incidência na } \\
\text { amostra (\%) }\end{array}$ \\
\hline peroba-rosa & $\begin{array}{l}\text { Aspidosperma sp., provável } \\
\text { Aspidosperma polyneuron, } \\
\text { Apocynaceae. }\end{array}$ & $\begin{array}{c}1,2,3,4,6,7,9 \\
10,12,13,14,16 \\
17,18 \text { e } 23\end{array}$ & 57,70 \\
\hline abiurana & Pouteria sp., Sapotaceae & 11,24 e 26 & 11,50 \\
\hline $\begin{array}{l}\text { achurana ou pau- } \\
\text { cepilho }\end{array}$ & Vantanea sp., Humiriaceae & 5 & 3,85 \\
\hline guaraiúva & Securinega sp., Euphorbiaceae & 8 & 3,85 \\
\hline ipê & Tabebuia sp., Bignoniaceae & 15 & 3,85 \\
\hline tento & Ormosia sp., Leguminosae & 19 & 3,85 \\
\hline envira & Duguetia sp., Annonaceae & 20 & 3,85 \\
\hline araçá & Psidium sp., Myrtaceae & 21 & 3,85 \\
\hline angico-vermelho & Dinizia excelsa, Leguminosae & 22 & 3,85 \\
\hline $\begin{array}{l}\text { casco-de-tatu ou } \\
\text { umari }\end{array}$ & Heisteria sp., Olacaceae & 25 & 3,85 \\
\hline
\end{tabular}

Nas fotos 25 a 27 são apresentadas três das espécies de madeira identificadas na amostra - abiurana, angico-vermelho e ipê - para exemplificar a variabilidade de colorações e estruturas anatômicas existentes entre as madeiras. 

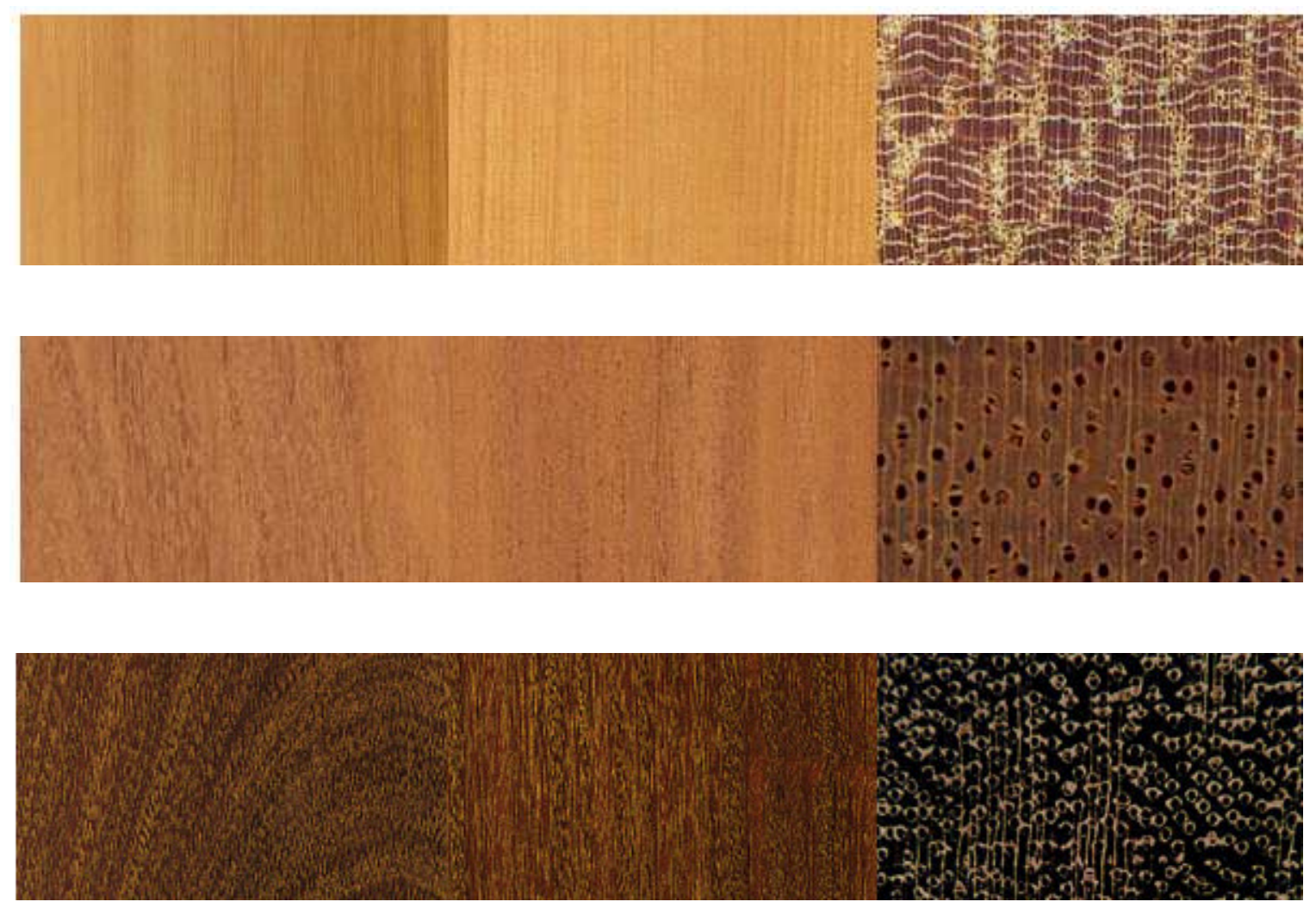

Fotos 25 a 27 - Faces tangencial, radial e fotomicrografia de Abiurana, angico-vermelho e ipê respectivamente (Fonte: IPT, 2010).

Uma vez que a amostra em epígrafe apresentou 10 espécies diferentes que ocorrem na Mata Atlântica, e que a peroba-rosa apresentou 57,7\% de incidência na amostra, pode-se inferir que nas edificações do centro histórico de São Luiz do Paraitinga em meados do século XIX, foram utilizadas madeiras regionais sem o controle rigoroso da espécie. A seleção das peças estaria mais fundamentada nos conhecimentos empíricos da madeira, do que nos conhecimentos científicos destas. Além de que fica confirmado o uso da espécie de peroba-rosa nas construções do século XIX e, por conseguinte, fica garantida a utilidade da validação do método ultrassônico para a espécie de peroba-rosa no patrimônio histórico.

Atualmente, o uso de microscópios ópticos e digitais e a disponibilidade de bancos de dados e imagens digitais permitem a identificação precisa da espécie da madeira. Isto, acrescido de um estudo de caracterização das propriedades mecânicas do material amostrado, facilita a comercialização da madeira por lotes mais homogêneos e com características físicas e mecânicas aproximadas. 


\section{$5.5 \quad$ ENSAIOS}

A seleção dos procedimentos de ensaio realizados baseou-se em avaliações e testes destrutivos e não-destrutivos em vigas de peroba-rosa com uso, retiradas de edificações com estruturas comprometidas pela falta de manutenção e vigas sem uso da serraria, respectivamente chamadas de Amostra A, Amostra B e Amostra C.

Os ensaios de caracterização física e mecânica da madeira de peroba-rosa foram conduzidos em laboratório utilizando procedimentos destrutivos e não destrutivos com o objetivo de relacionar os resultados e estimar a resistência da madeira por meio indireto dos ensaios não destrutivos. Tendo em consideração que diversos estudos apontaram para a correlação dos resultados obtidos em ensaios destrutivos seguindo a norma ABNT NBR 7190:1997 com os valores determinados da velocidade da onda ultrassônica em corpos-de-prova de diversas espécies, considera-se que os valores da velocidade ultrassônica obtidos com as amostras de peroba-rosa neste estudo podem ser validados para o uso do método não destrutivo direto.

A seguir são apresentados os ensaios laboratoriais em ordem de realização. Os ensaios não destrutivos foram os primeiros a serem realizados nas amostras de peroba-rosa para não terem seus resultados afetados pela ruptura dos corpos-deprova nos ensaios destrutivos.

\subsubsection{Retirada de corpos-de-prova}

Foram confeccionados corpos-de-prova prismáticos de seção transversal quadrada de $50 \mathrm{~mm}$ de lado com comprimentos de $150 \mathrm{~mm}$ e $1150 \mathrm{~mm}$, das três amostras de peroba-rosa.

Estas dimensões foram escolhidas, posto que a norma ABNT NBR 7190:1997 recomenda estas dimensões para a realização dos ensaios destrutivos de determinação das propriedades mecânicas da madeira. Uma vez que se adotou a comparação dos resultados obtidos pelo método do ultrassom com os obtidos pelos ensaios destrutivos normalizados, utilizaram-se os mesmos corpos-de-prova para todos os ensaios.

Os corpos de prova da figura 7, com dimensões de $50 \mathrm{~mm} \times 50 \mathrm{~mm}$ e 150 $\mathrm{mm}$ de comprimento na direção paralela às fibras da madeira, foram utilizados para 
os ensaios com ultrassom, na direção paralela às fibras $(09$ e normal às fibras (909; e para os ensaios de compressão módulo paralela às fibras.

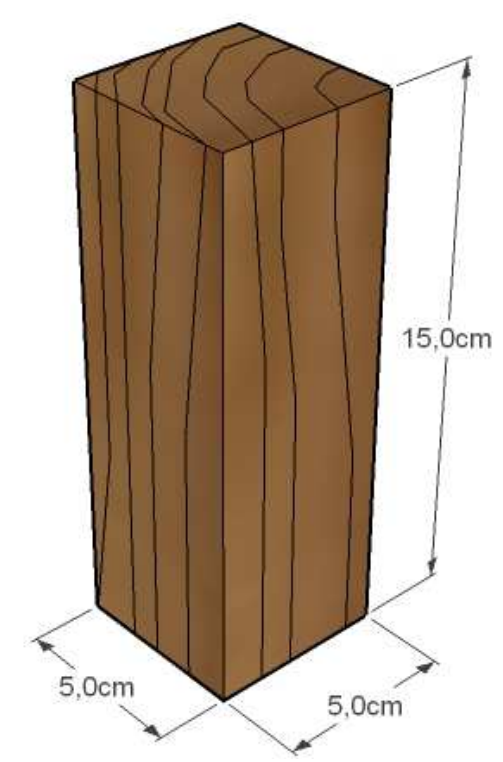

Figura 7 - Corpos-de-prova para determinação da resistência à compressão paralela às fibras, segundo a norma ABNT NBR 7190:1997.

Os corpos-de-prova da figura 8, com dimensões de $50 \mathrm{~mm} \times 50 \mathrm{~mm}$ e 1150 $\mathrm{mm}$, foram utilizados para os ensaios de ultrassom, direção paralela às fibras $(09) \mathrm{e}$ normal às fibras (909; e para os ensaios de determ inação da resistência à flexão módulo da peroba-rosa.

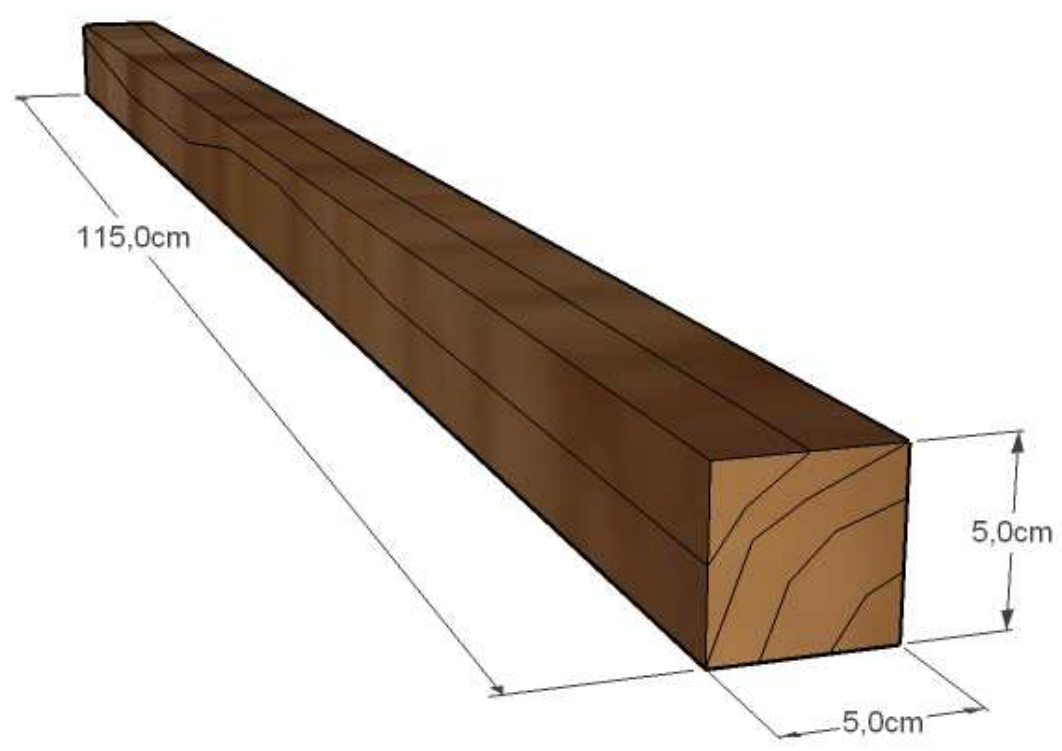

Figura 8 - Corpos-de-prova para determinação da resistência à flexão, segundo a norma ABNT NBR 7190:1997. 
As dimensões dos corpos-de-prova foram definidas conforme orientado na norma, Anexo B - Determinação das propriedades das madeiras para projeto de estruturas.

\subsubsection{Ensaios não destrutivos}

Foram selecionados dois equipamentos disponíveis no Laboratório de Madeira e Produtos Derivados do IPT, onde se realizaram os ensaios não destrutivos.

Os dois equipamentos atendem aos requisitos mínimos necessários de ergonomia, portabilidade e autonomia de energia para funcionamento, requeridos em uma inspeção in situ.

\subsubsection{Medição do teor de umidade da madeira}

A medição do teor de umidade determina uma característica física da madeira importante para o controle da resistência do material, pois as propriedades físicas da madeira são alteradas em função da quantidade de água nas paredes celulares do material.

A norma ABNT NBR 7190:1997 recomenda o ajuste das propriedades de resistência da madeira em função das condições ambientais onde permanecerão as estruturas de madeira. Dentro das classes de umidade, a madeira amostrada de peroba-rosa do estudo experimental foi acondicionada para a Classe de Umidade 1, que caracteriza a umidade relativa do ambiente menor ou igual a $65 \%$ e umidade de equilíbrio da madeira de $12 \%$.

$\mathrm{Na}$ Classe de Umidade 1 da norma, os valores das propriedades de resistência e de rigidez da madeira se constituem na condição-padrão de referência.

As Amostras A e B, retiradas das edificações construídas há 122 e 50 anos, respectivamente, tiveram sua umidade verificada com o uso de um higrômetro antes da retirada dos corpos-de-prova, apresentando teores de umidade em torno de $11 \%$ e $14 \%$, respectivamente.

Já a Amostra C, ou seja, madeira sem uso proveniente da serraria, teve sua umidade verificada na serraria estimada por higrômetro em $35 \%$. 
Em função do teor de umidade da Amostra $\mathrm{C}$ ter sido considerado acima do ponto de saturação das fibras, optou-se por acondicioná-la em ambiente ventilado e coberto até o ponto de equilíbrio de $12 \%$ de umidade, conforme apresentado na foto 28.

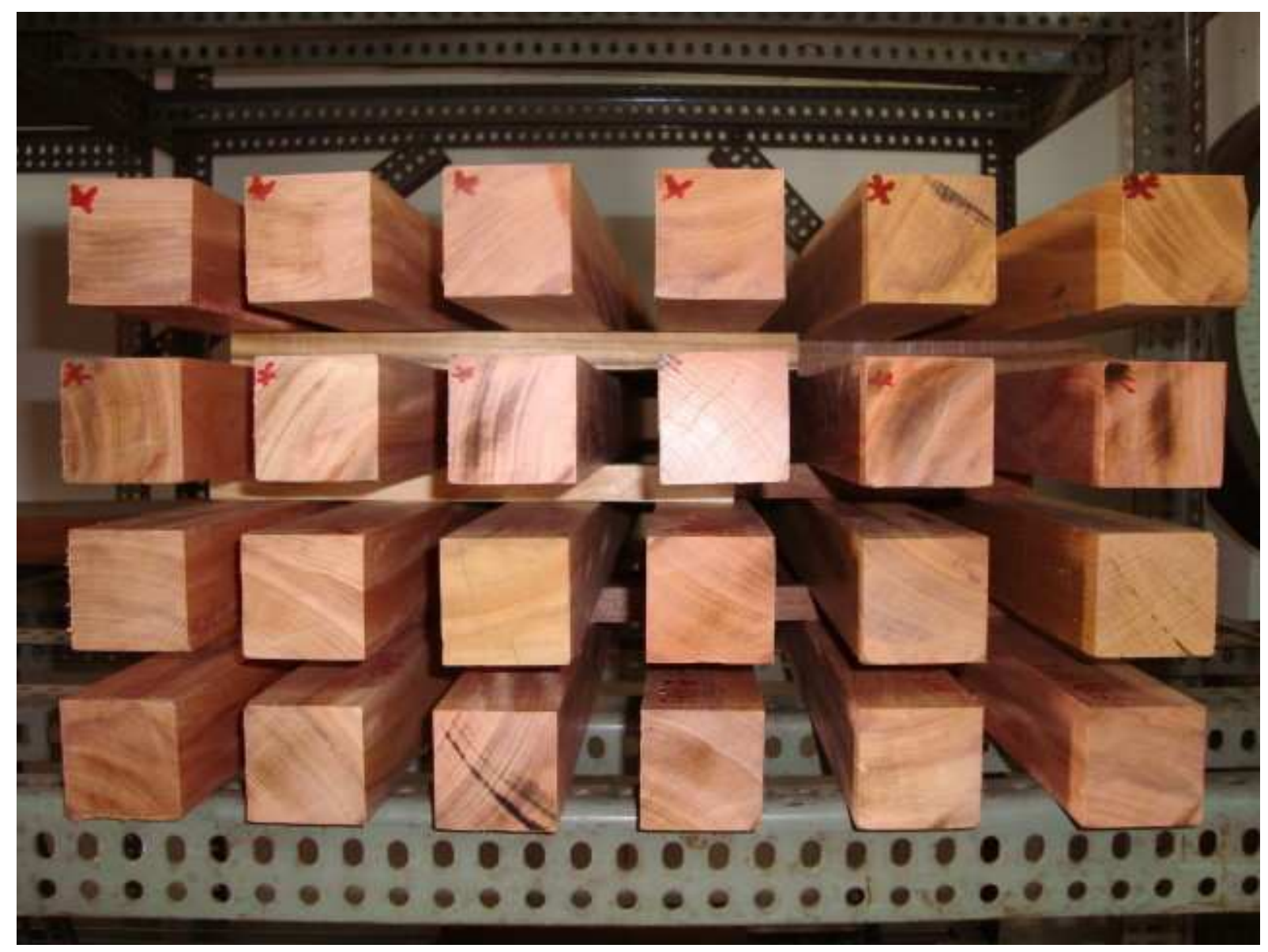

Foto 28 - Corpos-de-prova da Amostra C acondicionados em ambiente coberto e ventilado para o controle da secagem.

A realização do controle do teor de umidade das peças com o higrômetro permitiu que as três amostras fossem ensaiadas na condição-padrão de referência da norma, evitando também comportamentos diferentes dos corpos-de-prova no ensaio de ultrassom, com velocidades e atenuações.

O higrômetro utilizado para conferência da umidade nas peças não requer a retirada de corpos-de-prova e por isso é considerado um método não destrutivo.

O medidor do teor de umidade (higrômetro) da madeira do tipo resistência elétrica é geralmente um instrumento de corrente contínua, que opera com base no princípio que a resistividade da madeira varia numa faixa extremamente ampla à 
medida que se altera o seu teor de umidade. $O$ aparelho é projetado para medir a resistência elétrica entre dois eletrodos ou agulhas que são cravados na madeira de modo a permanecerem alinhados ao longo da grã (SANTINI e MATOS, 1995).

$\mathrm{O}$ teor de umidade definido com o equipamento da foto 29 foi aferido pelo método da NBR 7190:1997 de determinação do teor de umidade.

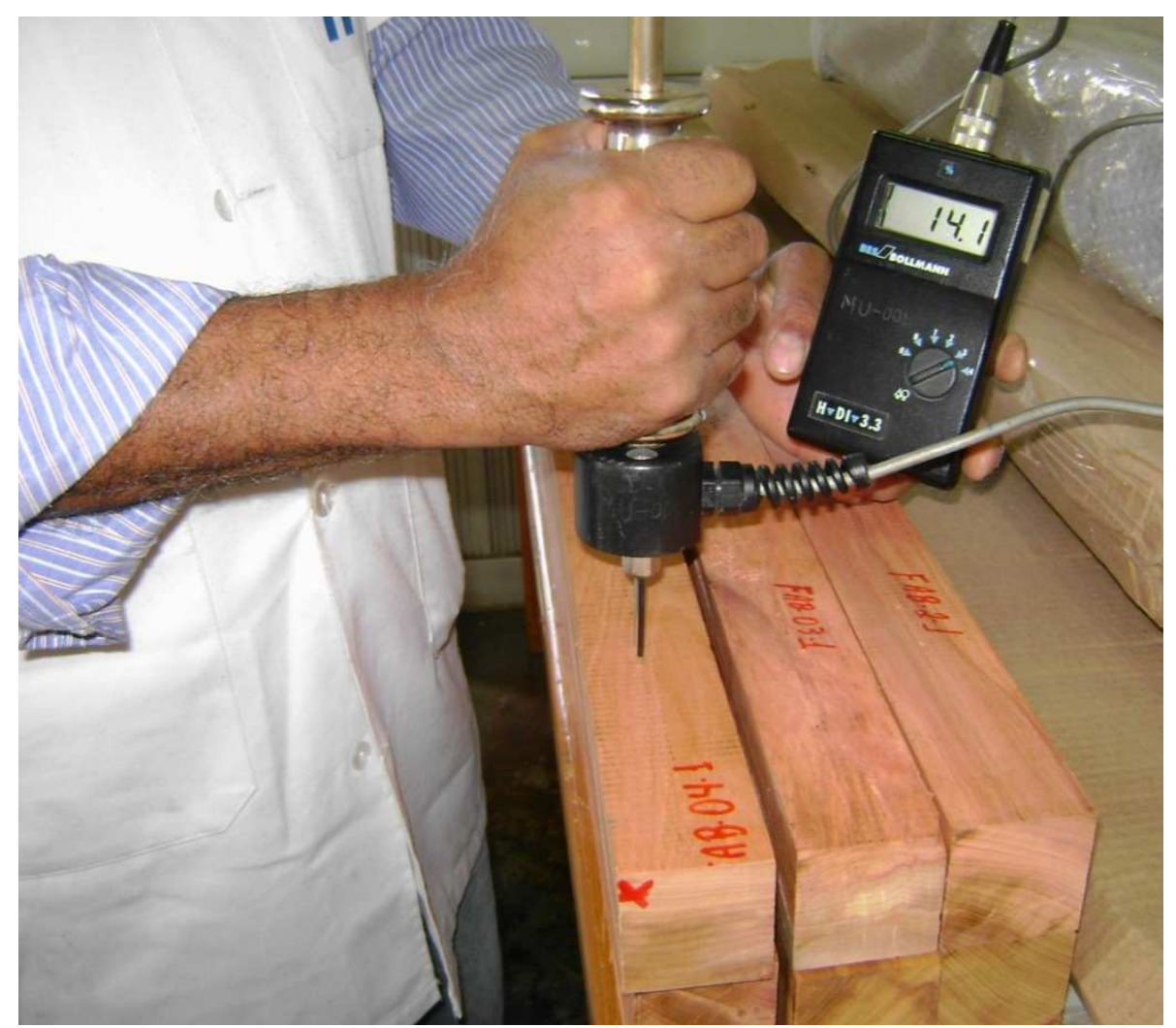

Foto 29 - Controle de medição de umidade dos corpos de prova de madeira da Amostra C para os ensaios de flexão.

Previamente à realização dos ensaios, os corpos-de-prova destinados ao ensaio de compressão tiveram sua massa inicial determinada em balança analítica com precisão de miligramas. E após a realização dos ensaios, os mesmos corposde-prova foram colocados na câmara de secagem do Laboratório de Madeira e Produtos Derivados do IPT à temperatura de $103^{\circ} \mathrm{C} \pm 2^{\circ} \mathrm{C}$ para a determinação da massa seca. Foram utilizados para isso os corpos-de-prova de compressão, pois suas dimensões permitiam que fossem colocados na câmara de secagem do Laboratório de Madeira e Produtos Derivados do IPT. 
O teor de umidade da madeira corresponde à relação entre a massa de água nela contida e a massa da madeira seca, dado por:

$$
U(\%)=\frac{m_{i}-m_{s}}{m_{s}} \times 100
$$

Onde:

$\boldsymbol{m}_{i}$ é a massa inicial da madeira, em gramas; e

$\boldsymbol{m}_{s}$ é a massa seca, em gramas.

Os resultados são apresentados na tabela 3 .

Tabela 3 - Amostras e corpos de prova para determinação do teor de umidade

\begin{tabular}{cccc}
\hline Amostra & $\begin{array}{c}\text { Número de } \\
\text { corpos de } \\
\text { prova }\end{array}$ & $\begin{array}{c}\text { Umidade } \\
\text { média } \\
(\%)\end{array}$ & $\begin{array}{c}\text { Desvio } \\
\text { padrão da } \\
\text { umidade }\end{array}$ \\
\hline A & 4 & 11 & $\mathbf{0 , 0}$ \\
B & 12 & 12 & $\mathbf{0 , 2}$ \\
C & 20 & 14 & $\mathbf{0 , 4}$ \\
\hline Média & - & $\mathbf{1 2}$ & $\mathbf{0 , 2}$ \\
\hline
\end{tabular}

Uma vez que as amostras apresentaram teores de umidade estáveis a 13\%, pode-se considerar que os ensaios não destrutivos e destrutivos foram realizados na condição-padrão de referência da norma NBR ABNT 7190:1997.

\subsubsection{Densidade}

O método de determinação da densidade utilizada no estudo foi o da densidade básica com base no método de ensaio da norma ABNT NBR 7190:1997. 
A densidade aparente é uma massa específica convencional, definida pela razão entre a massa e o volume de corpos-de-prova com teor de umidade a $12 \%$, sendo dada pela seguinte fórmula:

$$
\rho_{a p}=\frac{m_{12}}{V_{12}}
$$

Onde:

$m_{12}$ é a massa da madeira a $12 \%$ de umidade, em quilogramas; e

$V_{12}$ é o volume da madeira a $12 \%$ de umidade, em metros cúbicos.

Os resultados médios são apresentados na tabela 5.

Tabela 5 - Resultados do ensaio de densidade nas amostras.

\begin{tabular}{cccc}
\hline Amostra & $\begin{array}{c}\text { Número de } \\
\text { corpos de } \\
\text { prova }\end{array}$ & $\begin{array}{c}\text { Densidade } \\
\text { média } \\
\left(\mathbf{k g} / \mathbf{m}^{3}\right)\end{array}$ & $\begin{array}{c}\text { Desvio } \\
\text { padrão da } \\
\text { densidade }\end{array}$ \\
\hline A & 4 & 772 & 0,00 \\
B & 10 & 782 & 0,01 \\
\hline C & 20 & 854 & 0,04 \\
\hline
\end{tabular}

A determinação da densidade aparente da madeira é importante, pois, é com esses dados e da velocidade do ultrassom que pode ser estimado o módulo de elasticidade dinâmico do material.

Considerando que se for admitida uma hipótese simplificadora, desprezando os produtos dos coeficientes de Poisson, as velocidades de propagação da onda de ultrassom no material podem ser obtidas com a fórmula, apresentada na norma ABNT NBR 15521, a seguir:

$$
V=\sqrt{\frac{E_{d}}{\rho_{M}}}
$$

Onde: 
$V$ é a velocidade do ultrassom na madeira;

$E_{d}$ é o módulo dinâmico do material; e

$\rho_{M}$ é a densidade da madeira.

Os resultados da densidade das amostras apresentaram pequeno desvio padrão dos resultados e densidades maiores à medida que diminui o tempo de exposição ao uso das peças, 122 anos, 50 anos e sem uso, respectivamente.

\subsubsection{Determinação da velocidade ultrassônica}

A metodologia de medição do ultrassom realizada nos corpos-de-prova das três amostras utiliza parcialmente os procedimentos de ensaio da norma ABNT NBR 15521:2007. Os resultados serão posteriormente relacionados com os determinados nos ensaios destrutivos de determinação da resistência à compressão e à flexão.

O método de ensaio foi elaborado em função do tipo de equipamento disponível, com suas limitações, tipo de transdutor e programa de leitura.

O equipamento utilizado foi o EPOCH4 da marca Panametrics com dois pares de transdutores de banda estreita, do tipo emissor e receptor. Um par de transdutores com diâmetro de $40 \mathrm{~mm}$ de emissão de ondas longitudinais e outro par de transdutores de emissão de ondas transversais, ou cisalhantes, com diâmetro de $25 \mathrm{~mm}$, ambos com freqüência de $100 \mathrm{kHz}$.

Os transdutores são de contato, e, portanto requerem o uso de acoplante, que no caso dos experimentos da pesquisa, foi utilizado o gel de uso medicinal à base de água.

O método de ensaio adotado consistiu em três leituras, duas medições nas duas seções de $50 \mathrm{~mm}\left(90^{\circ} \mathrm{em}\right.$ relação à direção das fibras) e uma no comprimento de $150 \mathrm{~mm}\left(0^{\circ} \mathrm{em}\right.$ relação à direção das fibras) nos corpos-de-prova. Nas seções foram medidas as velocidades de ultrassom nos eixos radial e tangencial e, no comprimento, foi determinada a velocidade ultrassônica no eixo longitudinal.

O material necessário para o ensaio foi:

- equipamento de emissão de ondas de ultrassom com osciloscópio, 
- par de transdutores,

- gel de uso medicinal,

- régua milimetrada, e

- material de anotação.

Para cada leitura foi anotado o tempo de percurso da onda ultrassônica em segundos e a distância em milímetros percorrida entre os transdutores, considerando que a velocidade ultrassônica pode ser calculada pela relação da distância percorrida pelo seu tempo, dado em metros por segundo.

Os resultados médios apresentados na tabela 4 são os da velocidade de ondas longitudinais, pois embora tenham sido utilizados os dois tipos de transdutores (ondas longitudinais e transversais), nos ensaios realizados a $0^{\circ} \mathrm{e} 90^{\circ}$ em relação às fibras dos corpos-de-prova, somente foi feita a leitura da onda longitudinal em ambos os tipos de emissão, ou seja, o primeiro sinal de onda identificado pelo transdutor receptor.

A onda transversal não foi identificada, pois não houve uma definição de critério para a sua determinação no espectro da onda.

Tabela 4 - Resultados médios do ensaio de ultrassom.

\begin{tabular}{|c|c|c|c|c|c|c|}
\hline \multirow[t]{2}{*}{ Amostra } & \multicolumn{2}{|c|}{$\begin{array}{l}\text { Direção perpendicular às } \\
\text { fibras }(909) \text { no eixo radial }\end{array}$} & \multicolumn{2}{|c|}{$\begin{array}{c}\text { Direção perpendicular às } \\
\text { fibras }(909 \text { no eixo } \\
\text { tangencial }\end{array}$} & \multicolumn{2}{|c|}{$\begin{array}{l}\text { Direção paralela às fibras } \\
\text { (09 no eixo longitudinal }\end{array}$} \\
\hline & $V(m / s)$ & Ed (MPa) & $V(m / s)$ & $\mathrm{Ed}(\mathrm{MPa})$ & $V(m / s)$ & Ed (MPa) \\
\hline A & 2175 & 36715 & 2024 & 31620 & 5231 & 21176 \\
\hline C & 2258 & 43620 & 2000 & 34282 & 5082 & 22433 \\
\hline Média & 2217 & 40168 & 2012 & 32951 & 5157 & 21805 \\
\hline
\end{tabular}

Nota: $V$ é a velocidade da onda ultrassônica e Ed é o módulo de elasticidade dinâmico estimado por meio dos demais resultados. 
No caso, os resultados da amostra B não foram apresentados na tabela 4, em conseqüência da perda dos dados na transferência do equipamento para o computador. Os valores determinados para o tempo de percurso da onda ultrassônica foram registrados no equipamento e transferidos por meio de um programa próprio do equipamento via cabo USB. Os dados de saída do equipamento são com extensão $4 \mathrm{CL}$, e o mesmo software do equipamento instalado no computador faz a transformação para a extensão XLS.

No entanto, as ondas de toda a amostra B foram apenas gravadas para serem tratadas em computador, para a avaliação espectral, após a realização dos ensaios destrutivos. Quando o erro na transferência foi percebido, os corpos-deprova da amostra já haviam sido rompidos nos ensaios destrutivos, o que inviabilizou os ensaios da referida amostra.

Um formato de saída editado em programa tipo planilha eletrônica, com os dados tabelados do espectro de onda (tempo de percurso $x$ amplitude de onda) é apresentado na figura 9 .

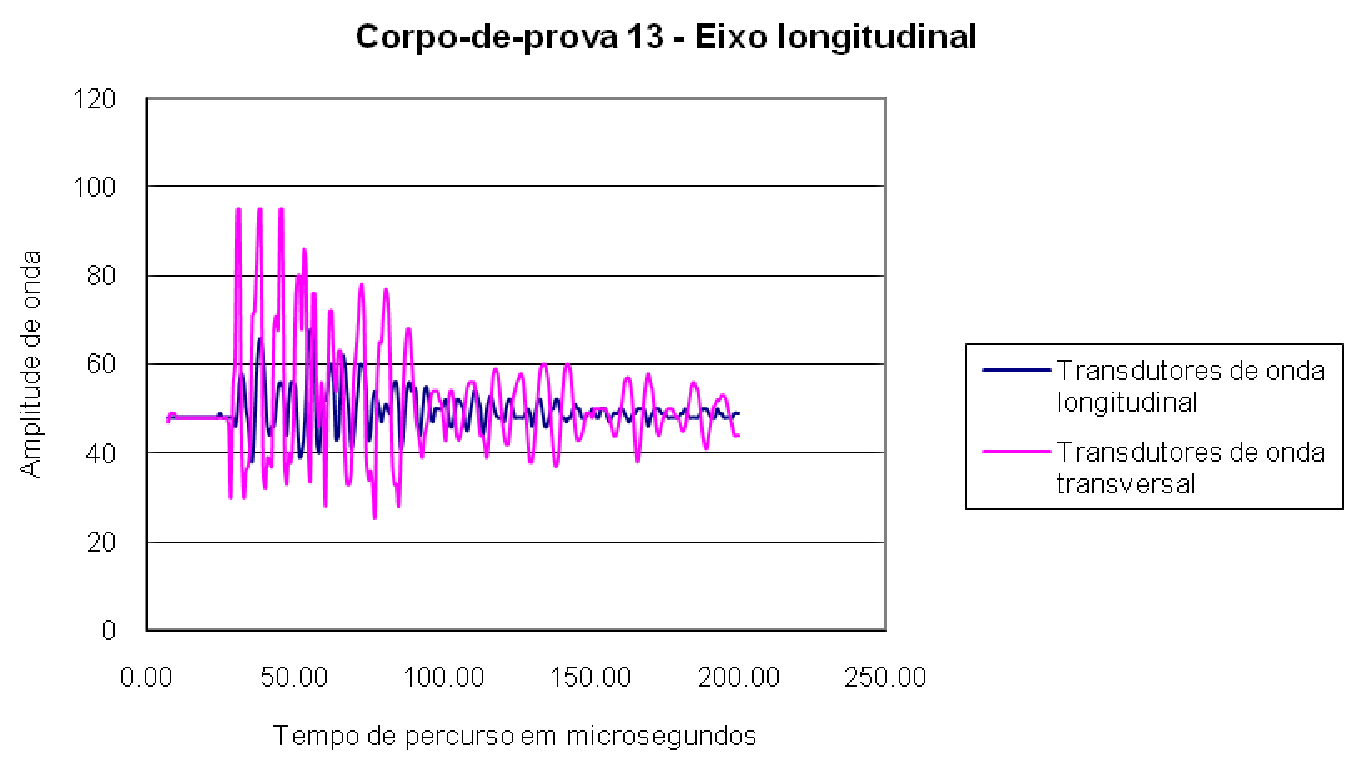

Figura 9 - Espectros de ondas dados pelas variáveis de amplitude $\mathrm{x}$ tempo de percurso com o uso de dois tipos de transdutores para corpo-de-prova na direção do eixo longitudinal.

As ondas de ultrassom foram agrupadas para cada corpo-de-prova, sendo sobrepostos os dados dos dois tipos transdutores (ondas longitudinais e 
transversais) para cada eixo. Os gráficos resultantes permitiram então, identificar a velocidade de onda ultrassônica mais rápida no corpo-de-prova, ou seja, a onda do tipo longitudinal, mesmo quando utilizado os transdutores de ondas transversais.

Cabe neste item, apresentar algumas orientações práticas para se evitar a perda de dados de ensaios de ultrassom nos equipamentos com aquisição de dados, tais como:

- conhecer o número limite de ondas que podem ser armazenadas pelo equipamento, e

- adotar as duas formas de registro dos dados, manual e armazenamento digital, para que ambos sejam rastreáveis.

Os resultados de cada corpo-de-prova da amostra $\mathrm{A}$ e $\mathrm{C}$ estão discriminados no Apêndice A.

\subsubsection{Ensaios destrutivos}

A caracterização da madeira consiste, em grande parte, na determinação de suas propriedades físicas, de resistência e rigidez por meio de ensaios normalizados, que demandam a retirada de corpos de prova e equipamentos de grande porte e de custos elevados.

A norma que rege os ensaios de caracterização das propriedades mecânicas da madeira para uso em construção civil é a ABNT NBR 7190:1997, a qual conduz aos procedimentos para a determinação da densidade básica e aparente, teor de umidade, resistência à compressão módulo de elasticidade nas direções paralela e perpendicular às fibras e resistência à flexão.

Essa norma prevê a retirada de corpos de prova e as propriedades mecânicas são definidas pelo carregamento das peças até a ruptura.

Os ensaios foram realizados no Laboratório de Madeira e Produtos Derivados da Madeira do IPT e no Laboratório de Construção Civil da EPUSP, com os equipamentos disponíveis nos laboratório. 


\subsubsection{Compressão}

O ensaio de determinação da resistência e da rigidez à compressão paralela às fibras da madeira foi realizado segundo os procedimentos da norma ABNT NBR 7190:1997.

A resistência à compressão é dada pela máxima tensão de compressão que pode atuar em um corpo-de-prova com seção transversal quadrada de $50 \mathrm{~mm}$ de lado e $150 \mathrm{~mm}$ de comprimento, sendo dada por:

$$
f_{c 0}=\frac{F_{c 0, \max x}}{A}
$$

Onde:

$f_{c 0}$ é a resistência à compressão paralela às fibras em megaPascals;

$F_{c 0}$, máx. é a máxima força de compressão aplicada ao corpo-de-prova durante o ensaio, em Newtons;

$A$ é a área inicial da seção transversal comprimida em metros quadrados.

Ainda segundo a norma, a rigidez da madeira na direção paralela às fibras é determinada por seu módulo de elasticidade, obtido do trecho linear do diagrama tensão por deformação específica expresso em megaPascals. Para a medição das deformações foram utilizados dois relógios comparadores com precisão de 0,001 $\mathrm{mm}$, fixados nas faces opostas por meio de duas cantoneiras metálicas aparafusadas no corpo-de-prova, com distância nominal de $100 \mathrm{~mm}$ entre as duas linhas de pregação.

O ensaio foi realizado em máquina universal de ensaio com carregamento aplicado com dois ciclos de carga e descarga, sendo a taxa de carregamento igual a $10 \mathrm{MPa} / \mathrm{min}$.

Os resultados para os valores médios são apresentados na tabela 6 . 
Tabela 6 - Valores médios das amostras

\begin{tabular}{ccc}
\hline Amostra & $\begin{array}{c}\text { Tensão de } \\
\text { ruptura } \\
\text { (MPa) }\end{array}$ & $\begin{array}{c}\text { Módulo de } \\
\text { elasticidade } \\
\text { (MPa) }\end{array}$ \\
\hline A & 61 & 13904 \\
C & 58 & 15738 \\
\hline Média & $\mathbf{6 0}$ & $\mathbf{1 4 8 2 1}$ \\
\hline
\end{tabular}

\subsubsection{Flexão}

O ensaio de determinação da resistência e da rigidez da madeira à flexão também foi realizado conforme o procedimento de ensaio apresentado na norma ABNT NBR 7190:1997.

A resistência da madeira à flexão é um valor dado pela máxima tensão que pode atuar em um corpo-de-prova no ensaio de flexão, dado por:

$$
f_{M}=\frac{M_{\text {máx. }}}{W_{e}}
$$

Onde:

$M_{\max }$ é o máximo momento aplicado ao corpo-de-prova, em Newtons.metro;

$W_{e}$ é o módulo de resistência elástico da seção transversal do corpo-de-prova, em metros cúbicos.

A rigidez da madeira à flexão é caracterizada pelo módulo de elasticidade determinado no trecho linear do diagrama de carga $x$ deslocamento, conforme 0 método da norma NBR 7190:1997.

Os resultados são apresentados na tabela 7. 
Tabela 7 - Valores médios das amostras

\begin{tabular}{ccc}
\hline Amostra & $\begin{array}{c}\text { Tensão de } \\
\text { ruptura } \\
\text { (MPa) }\end{array}$ & $\begin{array}{c}\text { Módulo de } \\
\text { elasticidade } \\
\text { (MPa) }\end{array}$ \\
\hline A & 100 & 15163 \\
\hline C & 102 & 12736 \\
\hline
\end{tabular}

Neste ensaio, constatou-se que as menores cargas de ruptura estavam relacionadas com as peças com a fibra revessa. Furos de insetos não foram relevantes para alteração dos resultados.

Tomando como referência os resultados do módulo de elasticidade da madeira em relação ao módulo de elasticidade dinâmico determinado pelo ensaio de ultrassom na direção longitudinal, tem-se 0 coeficiente de correlação de $R^{2}=0,56$ para os corpos-de-prova de peroba-rosa. 


\section{EXPERIMENTO IN SITU}

Os experimentos práticos com o uso do ultrassom foram realizados em uma edificação da cidade de São Luiz do Paraitinga que é objeto de avaliação estrutural pelas equipes do IPT, Prefeitura de São Luiz do Paraitinga e CONDEPHAAT, para futuros projetos de restauração.

Trata-se de uma residência assobradada construída em 1852 e tombada pelo CONDEPHAAT em 1982, a qual teve suas estruturas abaladas pela ação da enchente de janeiro de 2010. Localiza-se na Praça Oswaldo Cruz, no centro histórico da cidade.

O objetivo foi o de avaliar a viabilidade da realização da determinação do módulo dinâmico do material em campo, em função da velocidade longitudinal ultrassônica.

Embora todas as peças de madeira apresentavam aparência caracterizada pela ação do tempo e da sujidade acumulada nas superfícies, fez-se a busca por uma peça de peroba-rosa retirando pequenas lascas de vigas e pilares.

A peça escolhida para o estudo de campo foi um pilar de madeira do pavimento térreo da edificação (fotos 30 e 31) identificada como sendo da espécie peroba-rosa. A seção da pilar é de $180 \mathrm{~mm}$ x $180 \mathrm{~mm}$ e a altura de 4 metros.

A avaliação do pilar permitiu a verificação das limitações do uso do ultrassom em condições reais de uma inspeção in situ e orientou para a definição de um método de ensaio de campo. 

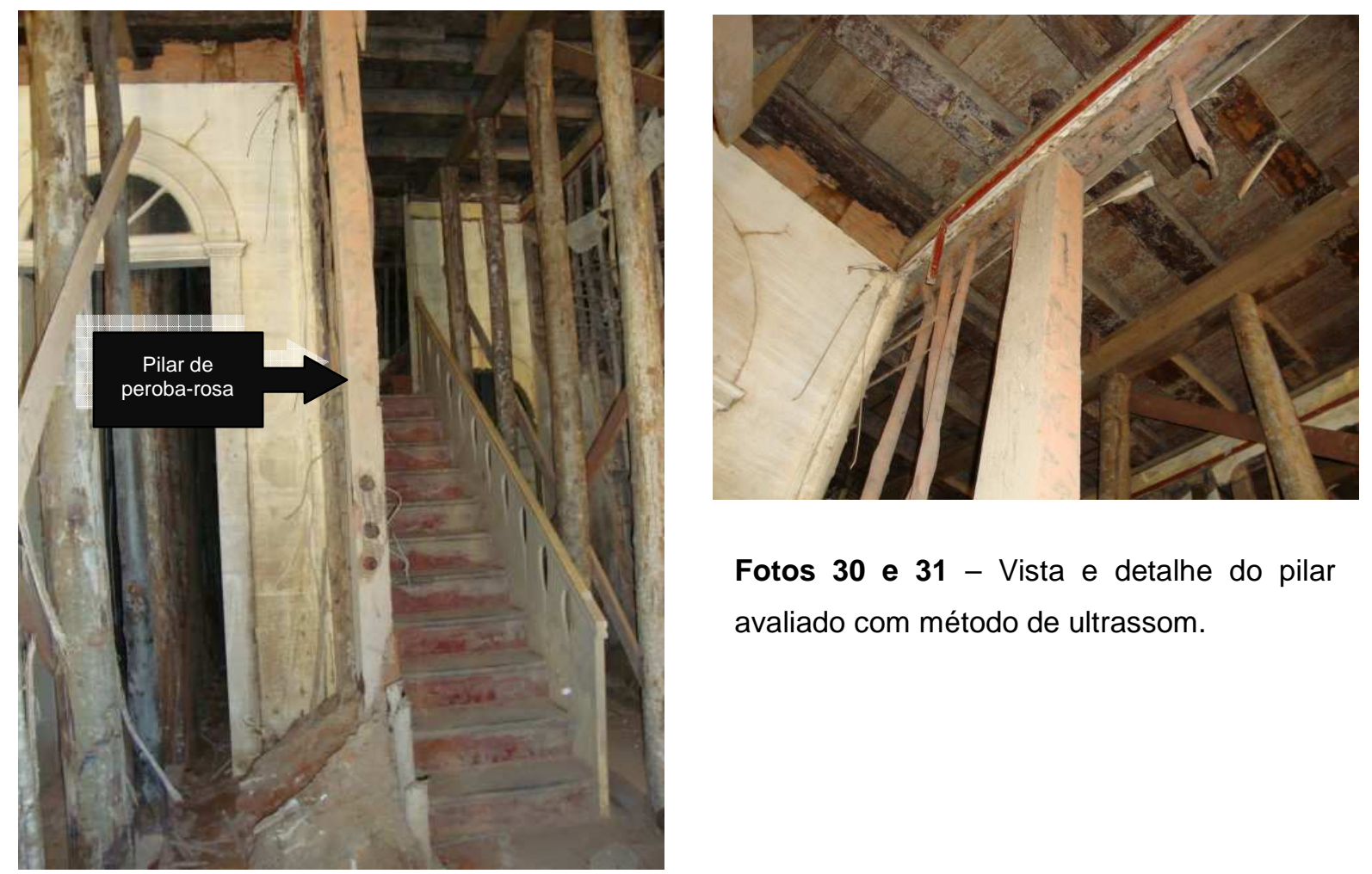

Fotos 30 e 31 - Vista e detalhe do pilar avaliado com método de ultrassom.

O equipamento utilizado foi o mesmo dos ensaios laboratoriais utilizado nas três amostras de peroba-rosa, o qual se utiliza de dois transdutores piezoelétricos (emissor e receptor) de ondas longitudinais com freqüência de $100 \mathrm{kHz}$, banda estreita, com visor, modelo EPOCH4, marca Panametrics.

O equipamento foi utilizado com bateria carregada em função da inexistência de fonte de energia no local.

Utilizou-se o gel medicinal, o mesmo acoplante utilizado nos ensaios laboratoriais, em bisnaga para facilitar o procedimento.

As leituras foram realizadas por duas pessoas, conforme apresentado na foto 32, que realizaram duas medições da velocidade da onda longitudinal, sendo uma medição na seção, com a orientação das fibras da madeira à $90^{\circ}$ e, outra no eixo longitudinal, com orientação das fibras à $0^{\circ}$. 


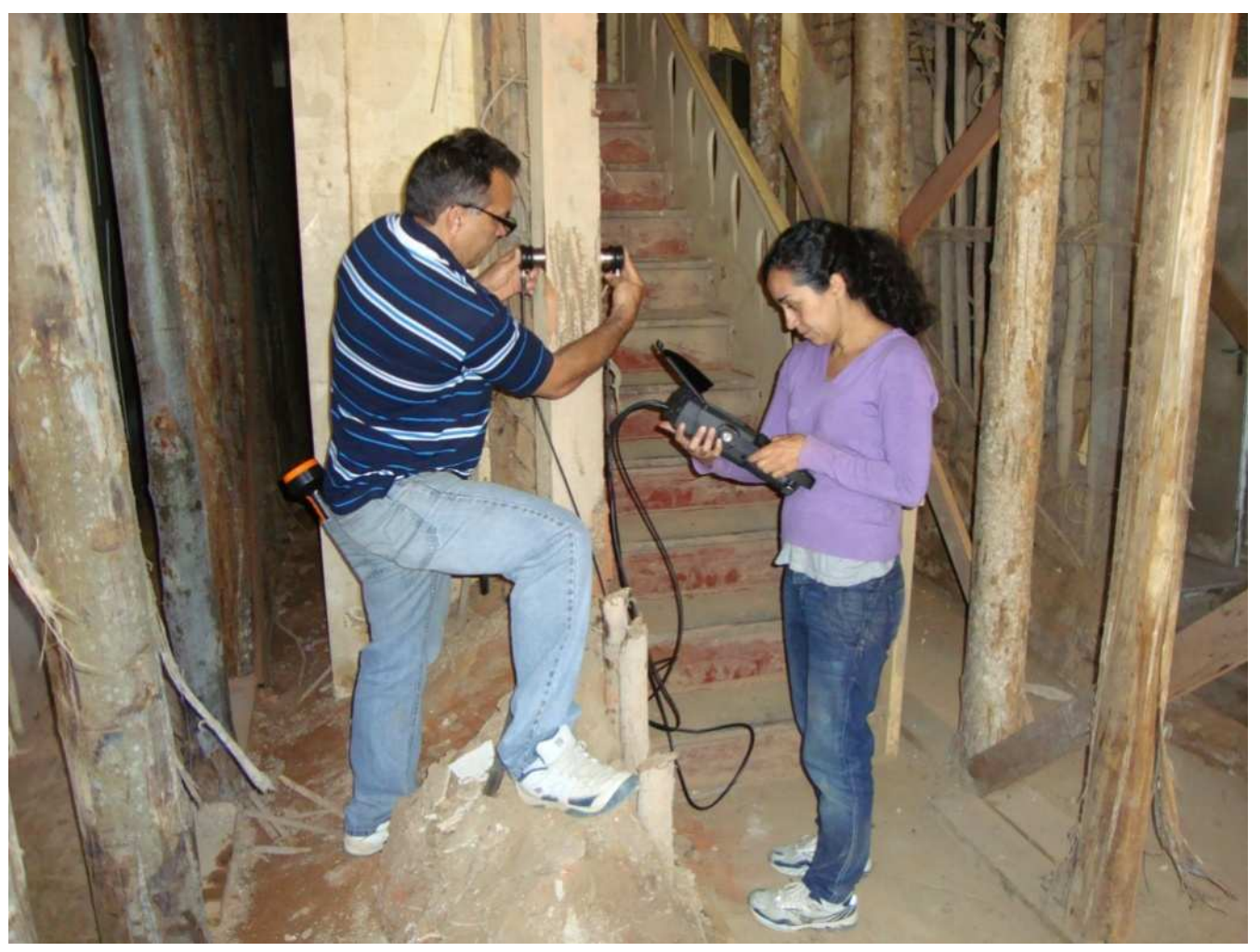

Foto 32 - Uso de equipamento para medir a velocidade longitudinal de ondas de ultrassom em seção de pilar de residência do século XIX em São Luiz do Paraitinga, construída com paredes de pau-a-pique, pilares e vigas de madeira e fundação de cantaria.

Em ambas as leituras, foi anotado o tempo de percurso dado pelo equipamento e a distância dos transdutores em milímetros.

Considerando que as condições encontradas em uma inspeção in situ são diferentes daquelas encontradas em laboratório avaliando peças serradas, foi feito um pequeno ajuste no procedimento, o qual diz respeito à superfície das peças de madeira. As peças de edificações antigas costumam ser lavradas, e por isso são irregulares dificultando a acoplagem dos transdutores. A solução foi muito simples, foi feita uma regularização que pode ser com lixa para madeira.

Em campo, todo o material deve estar disponível, bisnaga com gel acoplante, trena graduada em milímetros ou paquímetro, lixa para madeira, equipamento de emissão de ondas de ultrassom com bateria previamente carregada, par de transdutores e material de anotação.

$\mathrm{Na}$ tabela 8 são apresentados os resultados obtidos com o uso do ultrassom na peça estrutural de madeira identificada como sendo da espécie Aspidosperma polyneuron, ou seja, peroba-rosa. A peça de madeira inspecionada tinha a função de 
pilar do pavimento térreo, e não apresentava defeitos. Suas dimensões são de seção retangular de $180 \mathrm{~mm} \times 180 \mathrm{~mm}$ e 4 metros de altura.

O módulo dinâmico foi estimado de forma hipotética considerando a média da densidade das três amostras ensaiadas em laboratório, que foi de $803 \mathrm{~kg} / \mathrm{m}^{3}$, desconsiderando a variação do teor de umidade das peças.

Tabela 8 - Resultados do ensaio de campo

\begin{tabular}{cccc}
\hline Leitura & Direção das fibras & Velocidade $\left(\mathbf{m} / \mathbf{s}^{2}\right)$ & Ed (MPa) \\
\hline $\mathbf{1}$ & Paralela (a $\left.0^{\circ}\right)$ & 3333 & 8589 \\
$\mathbf{2}$ & Normal $\left(\right.$ a $\left.90^{\circ}\right)$ & 1923 & 2970 \\
\hline
\end{tabular}

A determinação da velocidade perpendicular às fibras foi realizada na seção do pilar, já a determinação da velocidade na direção paralela às fibras foi realizada na mesma face da viga com os transdutores espaçados em $150 \mathrm{~mm}$.

Embora os resultados apresentados no experimento em campo não possam expressar a condição real do ensaio de determinação da velocidade ultrassônica, pois o teor de umidade e a densidade de massa aparente não foram determinados, observou-se que o equipamento é viável e pode ser utilizado em testes de verificação da resistência de peças estruturais de madeira de peroba-rosa, se consideradas as variáveis de umidade e densidade.

Com relação ao peso e ao tamanho do equipamento de ultrassom adotado, ambas as características de portabilidade e autonomia corroboram para garantir a possibilidade de uso do equipamento em campo. 


\section{CONSIDERAÇÕES FINAIS}

Considerando a grande variabilidade de espécies de madeira e tipos de carregamento das peças encontradas em imóveis tombados, o escopo dos ensaios experimentais para verificação da validade do método ultrassônico se concentrou em uma espécie de madeira mais recorrente nesse tipo de edificação, a peroba-rosa (Aspidosperma polyneuron).

A madeira peroba-rosa havia sido previamente selecionada para a pesquisa pelo fato de não terem sido encontrados estudos com o uso de ultrassom para essa espécie na revisão bibliográfica. Mesmo porque os estudos de correlação dos módulos de elasticidade dinâmicos e estáticos conduzidos em laboratório são geralmente destinados à verificação de postes e controle de qualidade de peças serradas de espécies comercializadas, tais como pinus e eucalipto.

No caso do patrimônio histórico, os ensaios conduzidos em espécies nativas regionais tornam-se diretriz para que a metodologia seja reproduzida em situações reais de diagnóstico para projetos de restauração de estruturas de madeira.

Atualmente, a estimativa da resistência de peças avulsas de madeira serrada também utiliza métodos não destrutivos, inclusive, desde 2007 está vigente a norma ABNT NBR 15521, a qual discrimina as classes de resistência da madeira de dicotiledôneas através de uma classificação por ultrassom com medições na direção paralela às fibras. A velocidade de ultrassom na direção paralela às fibras é interessante para verificar a peça como um todo, de topo a topo, porem nem sempre é possível de ser realizada em pecas de edificações em uso, considerando que as peças estruturais em edificações geralmente estão engastadas ou apoiadas. Portanto a estimativa de padrões de velocidade de ultrassom na direção normal às fibras são válidos para a verificação da resistência mecânica e classificação de pecas do patrimônio histórico.

Ainda sobre a seleção da espécie que orientou a pesquisa, o estudo amostral que indicou $57,7 \%$ de incidência da peroba-rosa conduzido na cidade de São Luiz do Paraitinga corrobora com as citações bibliográficas que indicam o uso exaustivo da espécie nos patrimônio histórico e nas edificações construídas até o século XX. 
Nos 26 segmentos de madeira da amostra foram identificadas 10 espécies diferentes.

O estudo experimental conduzido em três amostras de peroba-rosa consistiu de caracterização física, mecânica e dinâmica da madeira.

$\mathrm{Na}$ caracterização física, a determinação de umidade aparente e densidade de massa são importantes para subsidiar os resultados de módulo de elasticidade dinâmico da madeira, assim como a inspeção visual das peças.

Em relação ao uso do ultrassom, os resultados dos ensaios com ambos os pares de transdutores, emissão de ondas longitudinais e emissão de ondas transversais de $100 \mathrm{kHz}$, somente permitiram a determinação da velocidade de onda longitudinal, pois não foram definidos critérios para a determinação da velocidade de onda transversal. Estes critérios devem considerar o uso de filtros por meio de transdutores com controle do ângulo de transmissão ultrassônica.

As determinações da velocidade do ultrassom nos corpos-de-prova com os transdutores localizados nas seções de $50 \mathrm{~mm}$, ou seja, a 90 em relação à direção das fibras da madeira, realizados no sentido do eixo transversal e no sentido do eixo radial não apresentaram diferenças significativas. Desta forma, conclui-se que para a madeira de peroba-rosa, o ultrassom na freqüência de $100 \mathrm{kHz}$ não se mostrou sensível a variação do eixo no plano transversal da madeira.

Em relação à freqüência dos transdutores, embora alguns corpos-de-prova apresentaram baixa resistência à flexão nos ensaios destrutivos, os mesmos não apresentaram alteração significativa na velocidade ultrassônica. Isso se deve a que os defeitos na madeira de peroba-rosa, devido a sua estrutura anatômica e resistência aos xilófagos, são predominantemente furos pequenos de insetos, menores que $3 \mathrm{~mm}$, e presença de fibra revessa. A fibra revessa afeta principalmente a resistência a flexão, tendo menor importância na resistência a compressão da madeira. No que tange à detecção de furos e vazios, têm-se que nas velocidades ultrassônicas determinadas nos ensaios experimentais com a peroba-rosa não houve atenuação da onda pela presença destes defeitos. Há de se considerar portanto, que furos e vazios com dimensão menores que o comprimento de onda não são identificados. 
Há atualmente no mercado, equipamentos que se utilizam de softwares de leitura e tipos de transdutores com freqüências diferentes ao utilizado no estudo, os quais permitem a verificação e quantificação de vazios e defeitos no material com transdutores de eco e ondas guiadas.

No caso do estudo, a determinação do módulo dinâmico das ondas longitudinais por meio da velocidade de ultrassom no formato espectral de onda foi considerado suficiente para a estimativa da resistência mecânica da peça avaliada principalmente para a os esforços de compressão. Para os esforços de flexão, o ensaio não foi sensível a presença de fibra revessa. Caberia, portanto, considerar que a inspeção visual das peças poderia ser incluída na metodologia de análise das peças estruturais, com a verificação de defeitos de fibra e furos pode orientar qualitativamente a avaliação estrutural.

No ensaio de campo, não foi possível determinar a onda longitudinal na leitura à $0^{\circ}$ em relação às fibras da madeira por meio de leitura superficial, ou seja, na mesma face da peça, pois é preciso aferir a distância na qual é possível fazer essa determinação.

Contudo, conclui-se que a verificação da resistência da madeira de perobarosa por meio da velocidade ultrassônica foi alcançada e se mostrou uma metodologia prática, expedita, quantitativa e que, principalmente, não requer a retirada de material, podendo ser utilizada em diagnósticos e avaliações de estruturas do patrimônio histórico. Em relação ao coeficiente de correlação dos módulos dinâmicos e estáticos na direção longitudinal, estimado em $R^{2}=0,56$, tem-se que os estudos apenas foram conduzidos em corpos-de-prova reduzidos. Novos estudos realizados em seções estruturais podem oferecer melhores índices de correlação e, portanto, considera-se que este índice não é restritivo para o seu uso como método de avaliação das peças estruturais.

Uma consideração secundária, porém não menos importante, é que a idealização deste estudo partiu do respeito às obras do passado, às técnicas de carpintaria e às florestas nativas que oferecem as madeiras com cores e texturas que nenhum outro material manufaturado consegue alcançar.

Algumas espécies que poderão ser estudadas com o uso do ultrassom são a abiurana, achurana ou pau-cepilho, guaraiúva, ipê, tento, envira, araçá, angico- 
vermelho e casco de tatu, as quais foram identificadas nas estruturas de edificações do século XIX na cidade de São Luiz do Paraitinga.

Fazer com que as árvores deixem ser cortadas para repor desnecessariamente as peças que há uma centena de anos foram falquejadas pelo trabalho dos técnicos carpinteiros que não existem mais, é um projeto que pode se tornar realidade com o uso dos métodos não destrutivos de avaliação mecânica, inclusive com o método de ultrassom e pode ser utilizado pelos profissionais de restauro para conservações preventivas e restaurações.

Enquanto ainda houver uma estrutura construída com tantas espécies de árvores as quais um dia não existirão mais nas florestas nativas, é valioso envidar os esforços possíveis para que as gerações futuras conheçam ao menos a madeira que seus antepassados conheciam tão bem. 


\section{REFERÊNCIAS}

ANDRÉ, N.; LABBÉ, N.; RIALS, T. G.; KELLEY, S. S. Assessment of wood load condition by near infrared (NIR) spectroscopy. Journal of Materials Science, v. 41, n. 7, p. 1879-1886, abril 2006.

ANDREUCCI, R. Ensaio por ultra-som. Disponíivel em <http://www.abende.org.br/apostilas/ensaioporultrasom.html> Acesso em: 12 ago. 2009.

APCR. Código de ética do conservador restaurador. Disponível em <http://www.apcr-sp.com.br/quemsomos/codetica.php>. Acesso em 10 jun. 2010.

ASSOCIACAO BRASILEIRA DE NORMAS TECNICAS. NBR 15521 - Ensaios não destrutivos - Ultra-som - Classificação mecânica de madeira serrada de dicotiledôneas. ABNT. São Paulo, 2007.

ASSOCIACAO BRASILEIRA DE NORMAS TECNICAS. NBR 7190 - Projeto de estruturas de madeira. ABNT. Rio de Janeiro, 1997.

AURICCHIO, A. L. R. Pau brasil. Disponível em: $<$ http://www.institutopaubrasil.org.br/show.cfm?t=7>. Acesso em: 10 de junho de 2009.

ARRUDA. Pinho de riga. Disponível em: <http://www.springerlink.com/content/u20167v140445700/> Acesso em: 10 jun. 2010.

BARROS, C. B. Validação de métodos analíticos. Biológico, São Paulo, v. 64, n.2, p.175-177, jul./dez. 2002.

BEAL, F.C. Future of nondestructive evaluation of wood and wood-based materials. Holzforschung-und-Holzverwertung, v. 8, n. 5, p. 73-75, 1996.

BODIG, J.; JAYNE, B. A. Mechanics of wood and wood composites. Nova lorque: Van Nostrand Reinhold, 1982.

BONAMINI, G. Restoring timber structures: Inspection and evaluation. Step Euroforthec, v. 2, 1995. 
BRAZOLIN, S. ; LELIS, A. T.; LOPEZ, G. A. C.; GUIMARÃES, F. P. O problema de fungos e insetos xilófagos no Museu de Arte Sacra de Salvador - Bahia: ABRACOR. Disponível em: $<\mathrm{http}$ ://www.abracor.com.br/novosite/pdfs/insetos_museu_arte_sacra.pdf>. Acesso em 5 maio 2010.

BUCUR, Voichita. Acoustics of Wood. 2 ed. Nova lorque: Springer, 2008. 393 p.

CABRAL, Diogo de Carvalho. Produtores reais e indústria madeireira no Rio de Janeiro do final do século XVIII: evidências empíricas para a região do Vale do Macacu. Ambiente \& Sociedade, Campinas, vol. 7, n. 002, p 125-143, 2004.

CAMARGOS, J.A.A. Catálogo de árvores do Brasil. Brasília:IBAMA, 2002. 896 p.

CARRASCO, E. V. M.; JÚNIOR, A. P. A. Avaliação não destrutiva de propriedades mecânicas de madeiras através de ultra-som - Fundamentos físicos e resultados experimentais. Revista Cerne, Lavras, v. 9, n. 2, p. 178-191, jul./dez. 2003.

CERALDI, C.; MORMONE, V.; ERMOLLI, R. Resistrographic inspection of ancient timber structures for the evaluation of mechanical characteristics. Materials and Structures, v. 34, p. 59-64, jan./fev. 2001.

CHOAY, F. A alegoria do patrimônio. São Paulo: Editira UNESP, 2001.

DE GROOT, R. C.; ROSS, R. J.; NELSON, W. J. Nondestructive assessment of wood decay and termite attack in southern pine sapwood. Wood Protection, v. 3, n. 2, p. 25-34, 1998.

DEMAUS, R.O. The DDD200 decay detecting drill: an evaluation of the drill's suitability for the assessment of structural timber in old buildings. Leominster: The Demaus Partnership, 1995. 20 p.

DEMAUS, R. Non-destructive investigations. Building Conservation. Disponível em: http://www.buildingconservation.com/articles/nondestr/nondestr.htm. Acesso em: 19 de dezembro de 2006.

EMERSON, R. N.; POLLOCK, D. G.; KAINZ, J. A. Nondestructive evaluation techniques for timber bridges. In: $5^{\text {th }}$ Montreal. Proceedings... Montreal: PUR, 1998. Disponível em: <http://www.ndt.net/articles/v04n11/emerson/emerson.htm>. Acesso em: 23 dez. 2008. 
ELEOTERIO, E. R.; BERTI FILHO, E. Levantamento e identificação de cupins (Insecta: Isoptera) em área urbana de Piracicaba - SP. Ciência Florestal, v.10, n.1, 2000.

FIGUEROA, F.Z.; LOPEZ, G.A.C.; MONTEIRO, M.B.B.; MIRANDA, M.J.A.C.; YOJO, $T$. Aplicação de método integrado para o diagnóstico de componentes construtivos de madeira em edificações históricas. In: Simpósio Latino americano sobre Métodos Físicos e Químicos em Arqueologia, Arte e Conservação de Patrimônio Cultural, 1², 2007, São Paulo. Anais do LASMAC 2007.

FUCKS, P. M. Os usos do patrimônio arquitetônico na atualidade: de produto cultural a atrativo turístico". Revista de Pesquisa e Pós-Graduação, Santo Ângelo, 2003.

GARCIA, F. S.; GUERNIERI, M. S.; PEREIRA, G. de F. e WEIHERMANN, S. Arquitetura em madeira: uma tradição paranaense. Scientia et Labor, Curitiba, 1987.

GIURANI. E; GUBANA, A. A penetration test to evaluate wood decay and its application to the Loggia monument. Materials and Structures, 1993, 26. p. 8-14.

GONZAGA, A. L. Madeira: uso e conservação. Brasília/DF: IPHAN/MONUMENTA, 2006. 248 p.

ICOMOS. Ancient timber structures in the Alpine area of Piedmont: Building systems, failures and decay: the heritage of the Canavese Valleys. In: Material to Structure - Mechanical behaviour and failures of the timber structures. IWC - XVI International Symposium: Italia, 2007.

ICOMOS. International Wood Committee. Principles for the preservation of wood structures. $12^{\circ}$ Assembléia Geral, México, Out. 1999. Disponív el em: http://www.icomos.org/iiwc/charter-eng.htm. Acesso em: 20 de fevereiro de 2007.

IPHAN. PAC Cidades Históricas: governo federal lança programa diferenciado com investimento na área cultural. Disponível em: $<$ http://portal.iphan.gov.br/portal/montarDetalheConteudo.do?id=14929\&sigla=Noticia \&retorno=detalheNoticia $>$. Acesso em 12/06/2010.

JULAR. Riga: informação genérica. Disponível em: < http://www.jular.pt/pdf//Riga_Info.pdf> Acesso em 10 jun. 2010. 
LA PASTINA FILHO, J. Manual de conservação de telhados. Brasília/DF:IPHAN, 2005. $88 \mathrm{p}$.

LARSTEN, H. J. Properties affecting reliability design of timber structures. In: COST E24 Seminar on Reliability of timber structures. Coimbra, Portugal. 4 a 5 Maio 2001.

LELIS, A. T. (coord.). Biodeterioração de madeiras em edificações. São Paulo: Instituto de Pesquisas Tecnológicas, 2001. (IPT. Publicação, 2686).

LEMOS, C. A. C. Alvenaria burguesa: breve historia da arquitetura residencial de tijolos em São Paulo a partir do ciclo econômico liderado pelo café. $2^{\mathrm{a}}$ Ed. São Paulo: Nobel, 1989. 205 p.

LIÑAN, C.R.; HITA, P.R. Evaluación del estado de la Madera en obras de rehabilitación mediante técnicas de ultrasonidos y obtención de parâmetros resistentes. Informes de la construcción, v. 47, n. 440, nov./dez., 0. 5-22, 1995.

LINDGREN, O. et al. Non-destructive wood density distribution measurements using computed tomography: a comparison between two scanners. Holz als Roh und Werkstoff, v.50, n. 7/8, p. 295-299, 1992.

LIVINGSTONE, R.A. Nondestructive Testing of Historic Structures. Archives and Museuns Informatics, v.13, n. 3-4, p. 249-271. Sept. 1999. Disponível em: < http://www.springerlink.com/content/u20167v140445700/> Acesso em: 12 jun. 2010.

LORENZI, H; SOUZA, H.M.; TORRES, M.A.V.;BACHER, L.B. Árvores exóticas no Brasil. São Paulo: Plantarum, 2003. 382 p.

MACHADO, J.S; CRUZ, H.; NUNES, L. Inspeções de elementos estruturais de madeira: Seleção das técnicas não-destrutivas a aplicar in situ. In: Encontro sobre Conservação e Reabilitação de Edifícios, ENCORE. Lisboa: Laboratório Nacional de Engenharia Civil. Tema 3, p.265-274. Cópia sem data.

MADY, F. T. M. Conhecendo a Madeira: Informações sobre 90 espécies comerciais. 1 Ed. Amazonas: SEBRAE. Programa de Desenvolvimento Tecnológico, 2000. 212 p.

MAINIERI, C.; CHIMELO, J. P. Fichas de características das madeiras brasileiras. São Paulo: IPT, 1989. 417 p. 
MARAGNO, A. S. A sistematização das causas de patologias em madeiramento estrutural de coberturas em edificações antigas. 2004. Dissertação de Mestrado, Programa de Pós-Graduação em Engenharia Civil - Universidade Federal Fluminense, Niterói.

MARK, R.E. Cell wall mechanics of tracheids. Michigan: The MacKay Press, 1967. $310 \mathrm{p}$.

MUSEU NACIONAL DO MAR. Arquivo. Disponível em http://www.museunacionaldomar.com.br/estrutura/bahia.htm. Acessado em: 25 de agosto de 2009.

NOGUEIRA, M.; BALLARIN, A. W. Sensibilidade dos ensaios de ultra-som a ortotropia elástica da madeira. In: PANNDT, 2003, Rio de Janeiro. Anais... Rio de Janeiro: PANNDT, 2003.

OLIVEIRA, F. G. R. de; CANDIAN, M.; LUCCHETTE, F. F.; CALIL JUNIOR, C; SALES, A. Avaliação de propriedades mecânicas de madeira por meio de ultra-som. In: PANNDT, 2003, Rio de Janeiro. Anais... Rio de Janeiro: PANNDT, 2003.

OLIVEIRA, F de. G. R.; SALES, A. Propagação de ondas acústicas na madeira. In: VII ENCONTRO BRASILEIRO EM MADEIRA E EM ESTRUTURA DE MADEIRA, 2000, São Carlos. Anais... São Carlos: USP, 2000.

OLIVEIRA et al , 2006. Influência do teor de umidade e da densidade da madeira na velocidade ultra-sônica. São Paulo: ABENDE, 2006. 11 p.

O ESTADO DE SÃO PAULO. Dados indicam $\mathbf{4 0 \%}$ de imóveis de SP destruídos. Notícia de 04/01/2009. Disponível em: http://www.abril.com.br/noticias/brasil/dadosindicam-40-imoveis-tombados-sp-destruidos-226881.shtml. Acesso em: 5 de agosto de 2009.

O ESTADO DE SÃO PAULO. PAC das cidades históricas prevê $\mathbf{R} \$ \mathbf{1 5 0}$ mi por ano. Notícia de 02/06/2009. São Paulo. Disponível em: http://www.estadao.com.br/noticias/geral,pac-das-cidades-historicas-preve-r-150-mipor-ano,412352,0.htm. Acesso em: 20 de agosto de 2009.

PFEIL, W; PFEIL, M. Estruturas de Madeira. 6. ed. Rio de Janeiro: Livros Técnicos e Científicos Editora, 2003. 224 p.

PILODYN. Pilodyn wood tester. Disponível em: http://www.corvib.com/pilodyn/. Acesso em: 25 de março de 2007. 
PIZZOLATO, M.; JORNADA, D. H.; CATEN, C.; MULLER, A.F. Desenvolvimento e validação de métodos de ensaio. Disponível em:

$<$ http://www.producao.ufrgs.br/arquivos/disciplinas/387_leitura_3_artigo_sobre_msa.pdf>. Acesso em 18 jun. 2010.

PONTES, J. A. V. A preservação histórica na cidade de São Paulo. Revista da Associação Paulista de Conservadores e Restauradores de Bens Culturais, $n$. 3, 2004. p. 35.

PRESERVASP. Nossa cidade, nossa casa: conhecendo a arquitetura da cidade e aprendendo a cuidar ela. São Paulo: Associação PreservaSP, 2010.

RIZZO, B. E. (coord.). Centro de Estudos de estudos e pesquisa de desastres PRI: programa de recuperação de imóveis. Rio de Janeiro: CEPD/RJ, 2009. 14 p.

ROSS, R.J.; HUNT, M.O. Stress wave timing nondestructive evaluation tools for inspecting historic structures: a guide for use and interpretation. General Technology Report, n.119. Department of Agriculture Forest Service, 2000. 16 p.

SAIA, Luís. Morada Paulista. 2ª Ed. São Paulo: Editora Perspectiva, 1978. 311p.

SANTINI, E. J.; MATOS, J. L. M.. Relação entre resistência elétrica, temperatura e umidade para madeira de Pinus elliottii Engelm submetida a diferentes temperaturas de secagem: Resultados preliminares. Ciência Florestal, São Paulo, v.5, n.1, 1995. p. $139-154$.

SIMÕES JUNIOR, José Geraldo . Anhangabaú: História e urbanismo. São Paulo: SENAC, 2004.

TANASOIU, V.; MICLEA, C.; TANASOIU, C. Nondestructive testing techniques and piezoelectric ultrasonics transducers for Wood and built in wooden structures. Journal of Optoelectronics and Advanced Materials. v.4, n.4, dez. 2002, p. 949957.

TELES, C. D. M. Estruturas de madeira: proposta de metodologia de inspeção e correlação da velocidade ultra-sônica com o dano por cupins. Dissertação de Mestrado, Programa de Pós-Graduação em Engenharia Civil - UFSC, Florianópolis, 2002. 
TEREZO, R. F. Propriedades mecânicas de madeiras utilizadas em estruturas históricas e contemporâneas estimadas por meio de ultra-som. Dissertação de Mestrado, Programa de Pós-Graduação em Engenharia Civil - UFSC, Florianópolis, 2004.

TOLEDO, Benedito Lima de. São Paulo, três cidades em um século. São Paulo: Cosac Naify Edições, 2007. 191 pp.

VALLE, A.; TEREZO, R. F.; TELES, C. D. M. Uso de técnicas não-destrutivas no diagnóstico de patologias em estruturas de madeira. E-Mat - Revista de Ciência e Tecnologia de Materiais de Construção Civil, v. 1, n. 2, p. 148-157, nov. 2004.

SIMÕES J. R. Anhangabaú: História e urbanismo. São Paulo: Senac. São Paulo, 2004.

ZENID, G. J. (coord.). Madeira para móveis e construção civil. São Paulo: IPT/SCTDE, 2002. CD-ROM. (IPT. Publicação, 2779).

ZENID, G. J. (coord.). Madeira: uso sustentável na construção civil. 2 ed. São Paulo: IPT/SVMA, 2009.

USDA. Wood Handbook: wood as na engineering material. Madison: U.S. Department of Agriculture, 2010. Disponível em $<$ http://www.fpl.fs.fed.us/products/publications/specific_pub.php?posting_id=17961\& header_id=r> Acesso em: 15 jul. 2010. 


\section{Apêndice A - Resultados dos ensaios de ultrassom}

\begin{tabular}{|c|c|c|c|c|c|c|c|}
\hline \multicolumn{8}{|c|}{ ULTRASSOM - Direção das fibras da madeira $=90^{\circ}$ (ei xo radial) } \\
\hline \multicolumn{8}{|c|}{ AMOSTRA A } \\
\hline $\mathbf{C P}$ & Cód. FAB & $\begin{array}{c}\text { Tempo de } \\
\text { percurso } \\
(\mu \mathrm{s})\end{array}$ & Amplitude & $\begin{array}{l}\text { Distância } \\
\text { (mm) }\end{array}$ & $\begin{array}{l}\text { Velocidade } \\
\qquad(\mathrm{m} / \mathrm{s})\end{array}$ & $\begin{array}{c}\text { Densidade } \\
\left(\mathrm{kg} / \mathrm{m}^{3}\right)\end{array}$ & $\mathrm{Ed}(\mathrm{MPa})$ \\
\hline 1 & FAB-A-01 & 21.1 & 50 & 50.01 & 2370 & 500 & 2809 \\
\hline 2 & FAB-A-02 & 23.28 & 53 & 49.40 & 2122 & 773 & 3481 \\
\hline 3 & FAB-B-01 & 25.46 & 47 & 50.07 & 1967 & 747 & 2889 \\
\hline 4 & FAB-B-02 & 22.55 & 47 & 50.07 & 2220 & 793 & 3910 \\
\hline Média & & 23.10 & 49 & 49.89 & 2170 & 703 & 3272 \\
\hline D.P. & & 1.57 & 2.49 & 0.28 & 146.86 & 118.47 & 450 \\
\hline \multicolumn{8}{|c|}{ AMOSTRA C } \\
\hline $\mathrm{CP}$ & Cód. FAB & $\begin{array}{c}\text { Tempo de } \\
\text { percurso } \\
(\mu \mathrm{s})\end{array}$ & Amplitude & $\begin{array}{l}\text { Distância } \\
\text { (mm) }\end{array}$ & $\begin{array}{l}\text { Velocidade } \\
(\mathrm{m} / \mathrm{s})\end{array}$ & $\begin{array}{c}\text { Densidade } \\
\left(\mathrm{kg} / \mathrm{m}^{3}\right)\end{array}$ & Ed (Mpa) \\
\hline 5 & FAB-01-1 & 23.28 & 48 & 50.16 & 2155 & 873 & 4053 \\
\hline 6 & FAB-01-2 & 21.1 & 48 & 49.40 & 2341 & 909 & 4983 \\
\hline 7 & FAB-02-1 & 22.55 & 48 & 50.47 & 2238 & 850 & 4258 \\
\hline 8 & FAB-02-2 & 21.83 & 48 & 50.43 & 2310 & 838 & 4472 \\
\hline 9 & FAB-03-1 & 21.83 & 48 & 50.73 & 2324 & 847 & 4574 \\
\hline 10 & FAB-03-2 & 24.01 & 48 & 50.95 & 2122 & 810 & 3647 \\
\hline 11 & FAB-04-1 & 21.83 & 48 & 50.62 & 2319 & 894 & 4807 \\
\hline 12 & FAB-04-2 & 22.55 & 48 & 50.08 & 2221 & 840 & 4143 \\
\hline 13 & FAB-05-1 & 21.85 & 48 & 49.79 & 2279 & 880 & 4569 \\
\hline 14 & FAB-06-1 & 21.85 & 48 & 49.83 & 2281 & 807 & 4197 \\
\hline 15 & FAB-06-2 & 21.85 & 48 & 50.23 & 2299 & 845 & 4466 \\
\hline 16 & FAB-07-1 & 22.58 & 48 & 49.68 & 2200 & 857 & 4149 \\
\hline 17 & FAB-07-2 & 22.58 & 48 & 49.91 & 2210 & 816 & 3987 \\
\hline 18 & FAB-08-1 & 23.3 & 49 & 50.00 & 2146 & 861 & 3965 \\
\hline 19 & FAB-08-2 & 21.85 & 48 & 49.82 & 2280 & 845 & 4393 \\
\hline 20 & FAB-09-1 & 21.85 & 48 & 50.42 & 2308 & 761 & 4052 \\
\hline 21 & FAB-09-2 & 22.58 & 48 & 49.81 & 2206 & 789 & 3839 \\
\hline 22 & FAB-10-1 & 22.58 & 47 & 50.78 & 2249 & 926 & 4683 \\
\hline 23 & FAB-10-2 & 21.12 & 48 & 49.76 & 2356 & 936 & 5196 \\
\hline Média & & 22.03 & 48 & 50.19 & 2280 & 853 & 4443 \\
\hline D.P. & & 0.61 & 0.43 & 0.43 & 57.00 & 78.71 & 534 \\
\hline
\end{tabular}

Nota: D.P. = desvio padrão 


\begin{tabular}{|c|c|c|c|c|c|c|c|}
\hline \multicolumn{8}{|c|}{ ULTRASSOM - Direção das fibras da madeira $=90^{\circ}$ (ei xo tangencial) } \\
\hline \multicolumn{8}{|c|}{ AMOSTRA A } \\
\hline $\mathbf{C P}$ & Cód. FAB & $\begin{array}{c}\text { Tempo de } \\
\text { percurso } \\
(\mu \mathrm{s})\end{array}$ & $\begin{array}{c}\text { Amplitude } \\
\text { de onda }\end{array}$ & $\begin{array}{l}\text { Distância } \\
(\mathbf{m m})\end{array}$ & $\begin{array}{l}\text { Velocidade } \\
\quad(\mathrm{m} / \mathrm{s})\end{array}$ & $\begin{array}{c}\text { Densidade } \\
\left(\mathbf{k g} / \mathrm{m}^{3}\right)\end{array}$ & Ed (MPa) \\
\hline 1 & FAB-A-01 & 26.19 & 51.00 & 49.86 & 1839 & 773 & 2614 \\
\hline 2 & FAB-A-02 & 24.01 & 55.00 & 50.25 & 2093 & 773 & 3386 \\
\hline 3 & FAB-B-01 & 24.01 & 50.00 & 50.38 & 2098 & 747 & 3289 \\
\hline 4 & FAB-B-02 & 24.74 & 48.00 & 50.38 & 2036 & 793 & 3288 \\
\hline Média & & 24.74 & 51.00 & 50.22 & 2017 & 772 & 3144 \\
\hline D.P. & & 0.89 & 2.55 & 0.21 & 105 & 16 & 309 \\
\hline \multicolumn{8}{|c|}{ AMOSTRA C } \\
\hline $\mathrm{CP}$ & Cód. FAB & $\begin{array}{c}\text { Tempo de } \\
\text { percurso } \\
(\mu \mathrm{s})\end{array}$ & Amplitude & $\begin{array}{l}\text { Distância } \\
(\mathbf{m m})\end{array}$ & $\begin{array}{l}\text { Velocidade } \\
(\mathrm{m} / \mathrm{s})\end{array}$ & $\begin{array}{c}\text { Densidade } \\
\left(\mathrm{kg} / \mathrm{m}^{3}\right)\end{array}$ & Ed (Mpa) \\
\hline 5 & FAB-01-1 & 26.92 & 48.00 & 49.68 & 1845 & 873 & 2973 \\
\hline 6 & FAB-01-2 & 24.01 & 48.00 & 50.25 & 2093 & 909 & 3982 \\
\hline 7 & FAB-02-1 & 24.74 & 50.00 & 49.23 & 1990 & 850 & 3366 \\
\hline 8 & FAB-02-2 & 24.01 & 48.00 & 50.63 & 2109 & 838 & 3726 \\
\hline 9 & FAB-03-1 & 26.92 & 48.00 & 50.00 & 1857 & 847 & 2922 \\
\hline 10 & FAB-03-2 & 25.46 & 48.00 & 50.51 & 1984 & 810 & 3188 \\
\hline 11 & FAB-04-1 & 26.92 & 48.00 & 50.82 & 1888 & 894 & 3186 \\
\hline 12 & FAB-04-2 & 24.01 & 48.00 & 50.97 & 2123 & 840 & 3786 \\
\hline 13 & FAB-05-1 & 25.49 & 48.00 & 50.16 & 1968 & 880 & 3408 \\
\hline 14 & FAB-06-1 & 26.95 & 48.00 & 49.99 & 1855 & 807 & 2777 \\
\hline 15 & FAB-06-2 & 26.22 & 50.00 & 50.08 & 1910 & 845 & 3083 \\
\hline 16 & FAB-07-1 & 24.03 & 48.00 & 50.10 & 2085 & 857 & 3725 \\
\hline 17 & FAB-07-2 & 24.03 & 48.00 & 49.50 & 2060 & 816 & 3463 \\
\hline 18 & FAB-08-1 & 24.76 & 48.00 & 49.76 & 2010 & 861 & 3477 \\
\hline 19 & FAB-08-2 & 25.49 & 48.00 & 49.63 & 1947 & 845 & 3203 \\
\hline 20 & FAB-09-1 & 24.76 & 48.00 & 50.10 & 2023 & 761 & 3116 \\
\hline 21 & FAB-09-2 & 25.49 & 49.00 & 49.28 & 1933 & 789 & 2949 \\
\hline 22 & FAB-10-1 & 24.76 & 51.00 & 50.54 & 2041 & 926 & 3858 \\
\hline 23 & FAB-10-2 & 25.49 & 49.00 & 49.82 & 1954 & 936 & 3576 \\
\hline Média & & 25.13 & 49 & 49.94 & 1988 & 853 & 3375 \\
\hline D.P. & & 0.37 & 1.09 & 0.46 & 45 & 79 & 361 \\
\hline
\end{tabular}

Nota: D.P. = desvio padrão 


\begin{tabular}{|c|c|c|c|c|c|c|c|}
\hline \multicolumn{8}{|c|}{ ULTRASSOM - Direção das fibras da madeira = 0 (eixo longitudinal) } \\
\hline \multicolumn{8}{|c|}{ AMOSTRA A } \\
\hline CP & Cód. FAB & $\begin{array}{c}\text { Tempo de } \\
\text { percurso } \\
(\mu \mathrm{s})\end{array}$ & $\begin{array}{l}\text { Amplitude } \\
\text { de onda }\end{array}$ & $\begin{array}{l}\text { Distância } \\
\text { (mm) }\end{array}$ & $\begin{array}{l}\text { Velocidade } \\
(\mathrm{m} / \mathrm{s})\end{array}$ & $\begin{array}{l}\text { Densidade } \\
\left(\mathbf{k g} / \mathrm{m}^{3}\right)\end{array}$ & $\mathrm{Ed}(\mathrm{MPa})$ \\
\hline 1 & FAB-A-01 & 29.10 & 48 & 150.43 & 5155 & 773 & 20542 \\
\hline 2 & FAB-A-02 & 26.92 & 49 & 150.24 & 5572 & 773 & 23999 \\
\hline 3 & FAB-B-01 & 30.56 & 50 & 150.43 & 4908 & 747 & 17994 \\
\hline 4 & FAB-B-02 & 28.37 & 48 & 150.40 & 5287 & 793 & 22166 \\
\hline Média & & 28.74 & 48.75 & 150.38 & 5231 & 772 & 21175 \\
\hline D.P. & & 1.31 & 0.83 & 0.08 & 240 & 16.33 & 2207 \\
\hline \multicolumn{8}{|c|}{ AMOSTRA C } \\
\hline $\mathrm{CP}$ & Cód. FAB & $\begin{array}{c}\text { Tempo de } \\
\text { percurso } \\
(\mu \mathrm{s})\end{array}$ & Amplitude & $\begin{array}{l}\text { Distância } \\
\text { (mm) }\end{array}$ & $\begin{array}{l}\text { Velocidade } \\
(\mathrm{m} / \mathrm{s})\end{array}$ & $\begin{array}{l}\text { Densidade } \\
\left(\mathbf{k g} / \mathrm{m}^{3}\right)\end{array}$ & Ed (Mpa) \\
\hline 5 & FAB-01-1 & 28.37 & 48 & 150.05 & 5289 & 873 & 24421 \\
\hline 6 & FAB-01-2 & 28.37 & 49 & 150.24 & 5296 & 909 & 25493 \\
\hline 7 & FAB-02-1 & 28.37 & 48 & 150.44 & 5303 & 850 & 23902 \\
\hline 8 & FAB-02-2 & 31.29 & 48 & 150.20 & 4800 & 838 & 19310 \\
\hline 9 & FAB-03-1 & 29.10 & 50 & 150.16 & 5160 & 847 & 22553 \\
\hline 10 & FAB-03-2 & 28.37 & 48 & 150.06 & 5289 & 810 & 22662 \\
\hline 11 & FAB-04-1 & 26.92 & 49 & 150.69 & 5598 & 894 & 28013 \\
\hline 12 & FAB-04-2 & 28.37 & 48 & 150.50 & 5305 & 840 & 23639 \\
\hline 13 & FAB-05-1 & 29.13 & 48 & 150.79 & 5176 & 880 & 23580 \\
\hline 15 & FAB-06-1 & 28.40 & 48 & 150.35 & 5294 & 807 & 22617 \\
\hline 16 & FAB-06-2 & 27.67 & 49 & 150.31 & 5432 & 845 & 24935 \\
\hline 17 & FAB-07-1 & 29.13 & 50 & 150.18 & 5156 & 857 & 22778 \\
\hline 18 & FAB-07-2 & 28.40 & 48 & 150.35 & 5294 & 816 & 22870 \\
\hline 19 & FAB-08-1 & 27.67 & 48 & 150.34 & 5433 & 861 & 25418 \\
\hline 20 & FAB-08-2 & 33.50 & 50 & 150.19 & 4483 & 845 & 16984 \\
\hline 21 & FAB-09-1 & 28.40 & 48 & 150.21 & 5289 & 761 & 21289 \\
\hline 22 & FAB-09-2 & 29.13 & 48 & 150.29 & 5159 & 789 & 21002 \\
\hline 23 & FAB-10-1 & 29.13 & 49 & 150.20 & 5156 & 926 & 24619 \\
\hline 24 & FAB-10-2 & 28.40 & 49 & 150.26 & 5291 & 936 & 26201 \\
\hline Média & & 28.77 & 48.50 & 150.24 & 5224 & 853 & 23278 \\
\hline D.P. & & 0.37 & 0.50 & 0.04 & 66 & 79 & 2207 \\
\hline
\end{tabular}

Notas: D.P = desvio padrão 


\section{Apêndice B - Resultados dos ensaios destrutivos}

\begin{tabular}{|c|c|c|c|c|c|c|}
\hline \multicolumn{7}{|c|}{ Amostra A } \\
\hline \multirow[b]{2}{*}{ CP } & \multirow[b]{2}{*}{ Cód. FAB } & \multirow[b]{2}{*}{$\begin{array}{c}\text { Densidade } \\
\left(\mathbf{g} / \mathrm{m}^{3}\right)\end{array}$} & \multicolumn{2}{|c|}{ Compressão } & \multicolumn{2}{|c|}{ Flexão } \\
\hline & & & $\begin{array}{c}\text { Tensão } \\
\text { de } \\
\text { Ruptura }\end{array}$ & $\begin{array}{l}\text { MOE } \\
\text { (Mpa) }\end{array}$ & $\begin{array}{c}\text { Tensão } \\
\text { de } \\
\text { Ruptura }\end{array}$ & $\begin{array}{l}\text { MOE } \\
\text { (Mpa) }\end{array}$ \\
\hline 1 & FAB-A-01 & 773 & 60,96 & 14748 & 132 & 17641 \\
\hline 2 & FAB-A-02 & 773 & 60,80 & 14567 & 136 & 20200 \\
\hline 3 & FAB-B-01 & 747 & 60,26 & 14234 & 50 & $10392^{\star \star}$ \\
\hline 4 & FAB-B-02 & 793 & 60,36 & 12730 & 83 & 12421 \\
\hline Média & & 772 & 61 & 13904 & 100 & 15163 \\
\hline D.P. & & 16 & 0 & 856 & 36 & 3930 \\
\hline \multicolumn{7}{|c|}{ Amostra C } \\
\hline & & & \multicolumn{2}{|c|}{ Compressão } & \multicolumn{2}{|c|}{ Flexão } \\
\hline CP & Cód. FAB & $\begin{array}{c}\text { Densidade } \\
\left(\mathbf{k g} / \mathrm{m}^{3}\right)\end{array}$ & $\begin{array}{c}\text { Tensão } \\
\text { de } \\
\text { Ruptura }\end{array}$ & $\begin{array}{l}\text { MOE } \\
\text { (Mpa) }\end{array}$ & $\begin{array}{c}\text { Tensão } \\
\text { de } \\
\text { Ruptura }\end{array}$ & $\begin{array}{l}\text { MOE } \\
\text { (Mpa) }\end{array}$ \\
\hline 5 & FAB-01-1 & 873 & 56,18 & 13987 & 76 & $11095^{\star *}$ \\
\hline 6 & FAB-01-2 & 909 & 56,40 & 14218 & 106 & 14745 \\
\hline 7 & FAB-02-1 & 850 & 60,97 & 19883 & 112 & 13539 \\
\hline 8 & FAB-02-2 & 838 & 55,18 & 16391 & 98 & $10340^{*}$ \\
\hline 9 & FAB-03-1 & 847 & 61,66 & 15544 & 95 & $12360^{*}$ \\
\hline 10 & FAB-03-2 & 810 & 56,19 & 17744 & 104 & 13204 \\
\hline 11 & FAB-04-1 & 894 & 61,92 & 19054 & 111 & $14366^{*}$ \\
\hline 12 & FAB-04-2 & 840 & 63,31 & 17918 & 127 & 12186 \\
\hline 13 & FAB-05-1 & 880 & 60,10 & 16391 & 86 & $12786^{*}$ \\
\hline 15 & FAB-06-1 & 807 & 57,21 & 17162 & & \\
\hline 16 & FAB-06-2 & 845 & 62,97 & 14816 & & \\
\hline 17 & FAB-07-1 & 857 & 63,40 & 15526 & & \\
\hline 18 & FAB-07-2 & 816 & 54,04 & 16211 & & \\
\hline 19 & FAB-08-1 & 861 & 56,67 & 16833 & & \\
\hline 20 & FAB-08-2 & 845 & 57,71 & 15322 & & \\
\hline 21 & FAB-09-1 & 761 & 49,09 & 10595 & & \\
\hline 22 & FAB-09-2 & 789 & 57,52 & 15832 & & \\
\hline 23 & FAB-10-1 & 926 & 59,30 & 13179 & & \\
\hline 24 & FAB-10-2 & 936 & 60,67 & 12424 & & \\
\hline Média & & 852 & 58 & 15738 & 102 & 12736 \\
\hline D.P. & & 44 & 4 & 2197 & 14 & 1351 \\
\hline
\end{tabular}

Notas: D.P = desvio padrão

${ }^{*}$ corpos-de-prova com fibra revessa

${ }^{* *}$ corpo-de-prova com furos de insetos 